\title{
Proven Performance of Seven Cold Climate Deep Retrofft Homes
}

R. Osser, K. Neuhauser, and K. Ueno Building Science Corporation 


\title{
This report received minimal editorial review at NREL
}

\begin{abstract}
NOTICE
This report was prepared as an account of work sponsored by an agency of the United States government. Neither the United States government nor any agency thereof, nor any of their employees, subcontractors, or affiliated partners makes any warranty, express or implied, or assumes any legal liability or responsibility for the accuracy, completeness, or usefulness of any information, apparatus, product, or process disclosed, or represents that its use would not infringe privately owned rights. Reference herein to any specific commercial product, process, or service by trade name, trademark, manufacturer, or otherwise does not necessarily constitute or imply its endorsement, recommendation, or favoring by the United States government or any agency thereof. The views and opinions of authors expressed herein do not necessarily state or reflect those of the United States government or any agency thereof.
\end{abstract}

Available electronically at http://www.osti.gov/bridge

Available for a processing fee to U.S. Department of Energy and its contractors, in paper, from:

U.S. Department of Energy Office of Scientific and Technical Information

P.O. Box 62

Oak Ridge, TN 37831-0062

phone: 865.576 .8401

fax: 865.576 .5728

email: mailto:reports@adonis.osti.gov

Available for sale to the public, in paper, from:

U.S. Department of Commerce

National Technical Information Service

5285 Port Royal Road

Springfield, VA 22161

phone: 800.553 .6847

fax: 703.605.6900

email: orders@ntis.fedworld.gov

online ordering: http://www.ntis.gov/ordering.htm 


\title{
Proven Performance of Seven Cold Climate Deep Retrofit Homes
}

\author{
Prepared for: \\ Building America \\ Building Technologies Program \\ Office of Energy Efficiency and Renewable Energy \\ U.S. Department of Energy \\ Prepared by: \\ R. Osser, K. Neuhauser, and K. Ueno \\ Building Science Corporation \\ 30 Forest St. \\ Somerville, MA \\ NREL Technical Monitor: Cheryn Engebrecht \\ Prepared Under Subcontract No.: KNDJ-0-40337-00
}

June 2012 
[This page left blank] 


\section{Contents}

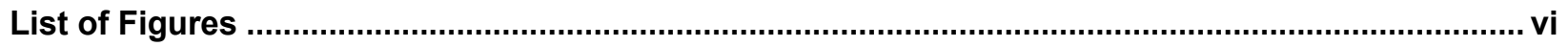

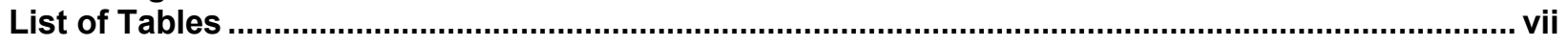

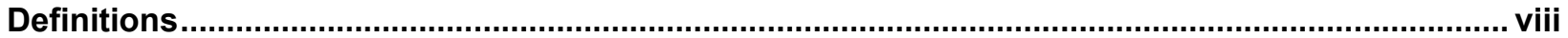

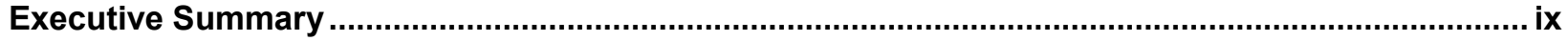

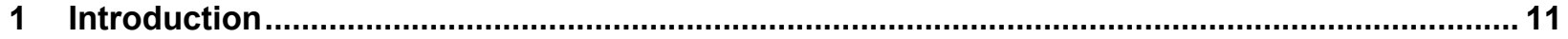

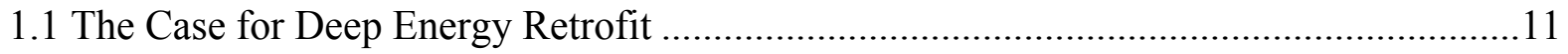

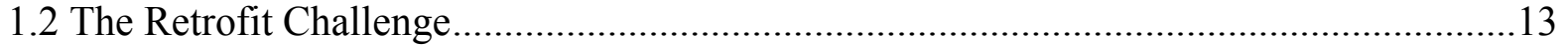

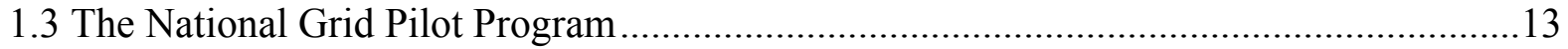

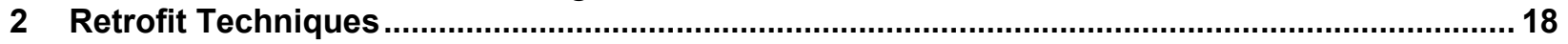

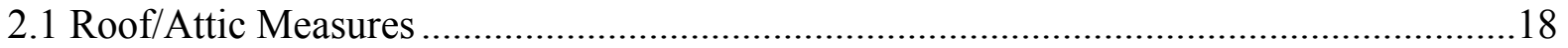

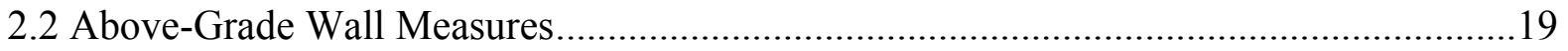

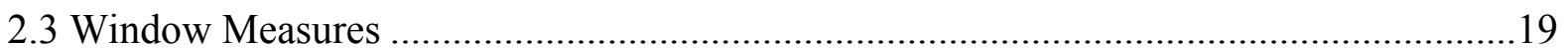

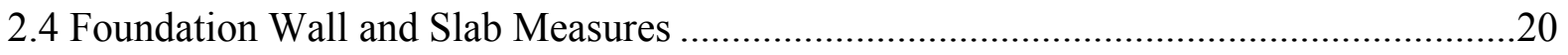

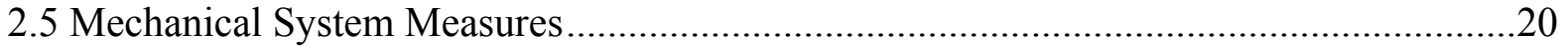

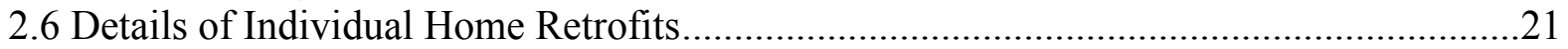

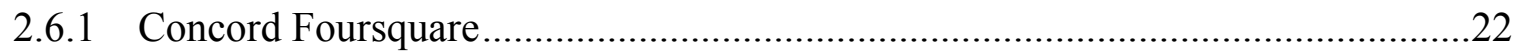

2.6.2 Bedford Farmhouse ....................................................................................26

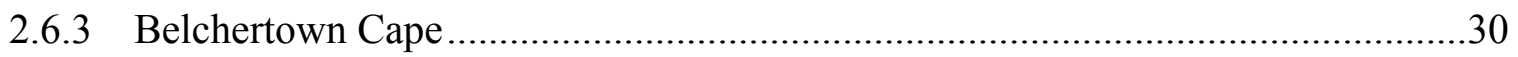

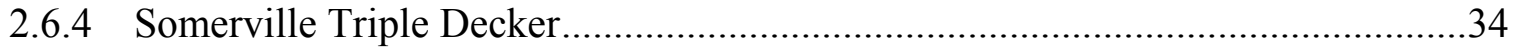

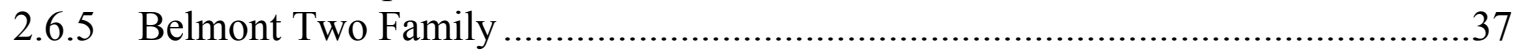

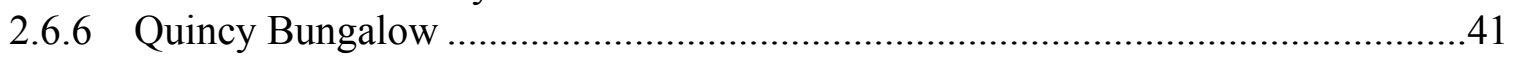

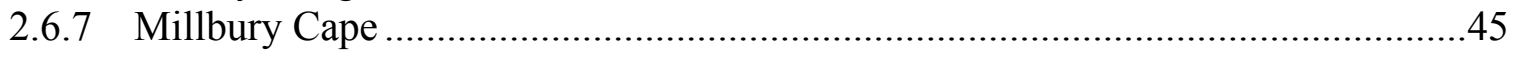

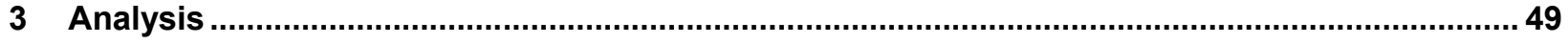

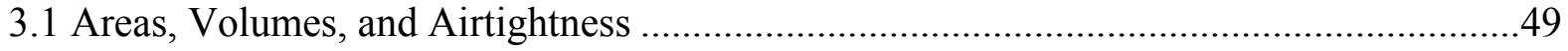

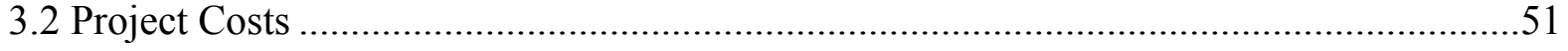

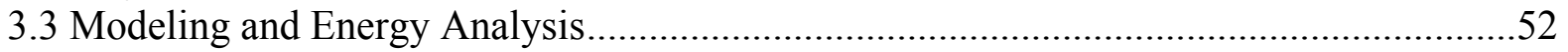

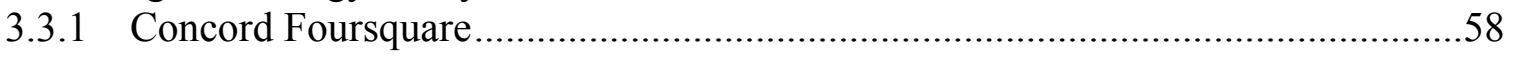

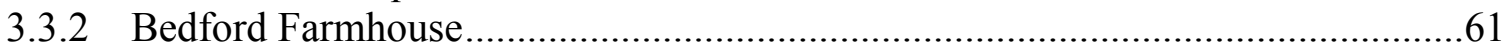

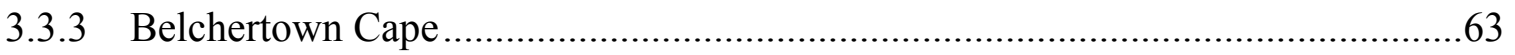

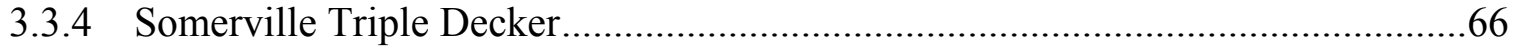

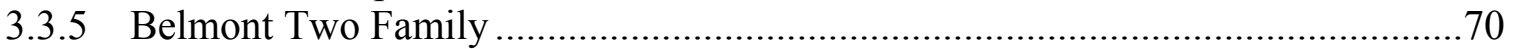

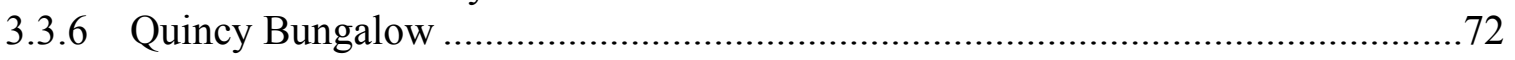

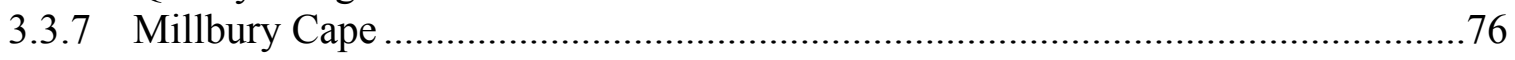

3.4 Weather and Energy Savings: ASHRAE Guideline 14-2002 and the Inverse Modeling

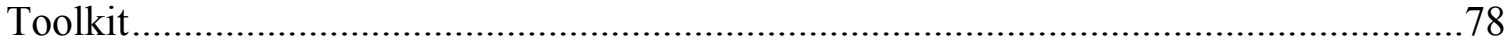

3.4.1 Whole Building Energy Approach: Somerville Triple Decker...........................78

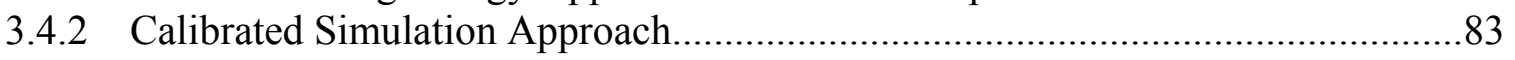

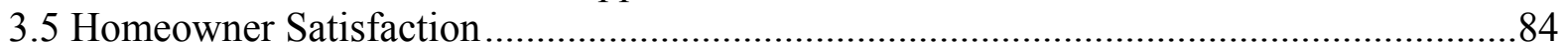

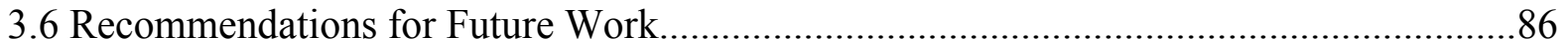

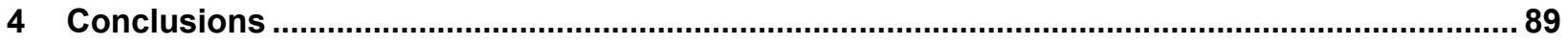

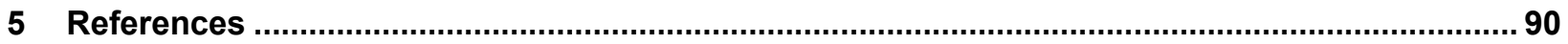

6 Appendix A 


\section{List of Figures}

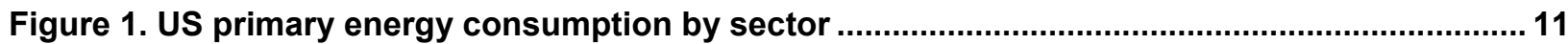

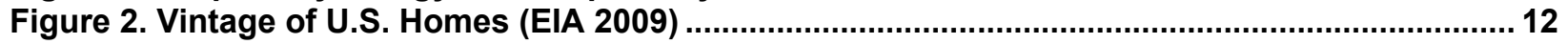

Figure 3. Sample pre- and post-DER heating load components.................................................... 12

Figure 4. Sample pre- and post-DER cooling load components................................................. 13

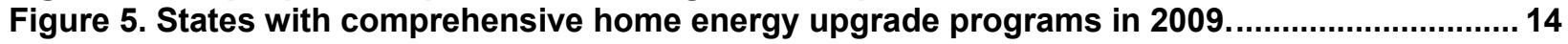

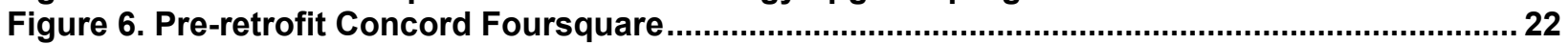

Figure 7. Post-retrofit Concord Foursquare ............................................................................... 22

Figure 8. Completed Bedford Farmhouse (Habitat for Humanity) …................................................... 26

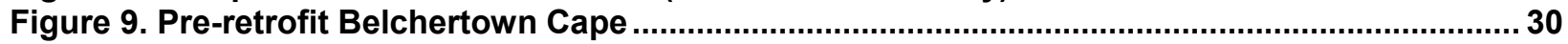

Figure 10. Post-retrofit Belchertown Cape ......................................................................................... 30

Figure 11. Pre-(left) and post (right) retrofit triple decker located in Somerville, Massachusetts ... 34

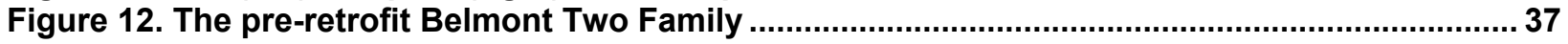

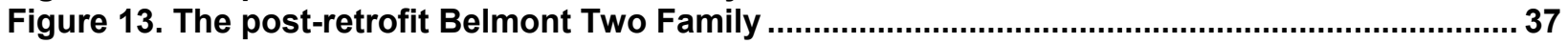

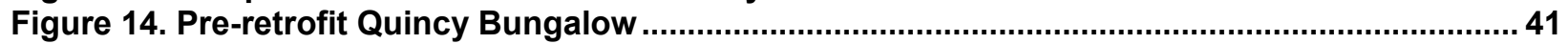

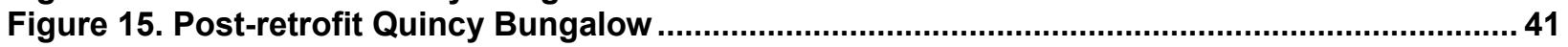

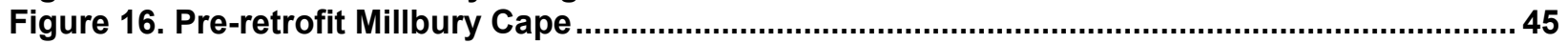

Figure 17. Post-retrofit Millbury Cape .......................................................................................... 45

Figure 18. Source-site energy ratios taken from EnergyStar.gov...............................................53

Figure 19. Source energy use before and after the retrofits for each of the 7 homes......................56

Figure 20. Source energy use per conditioned area (energy use index) compared to 2030

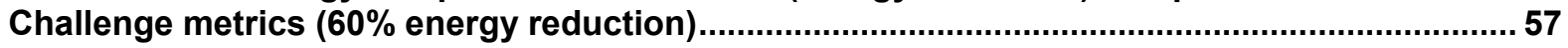

Figure 21. Concord Foursquare energy modeling comparison .................................................... 59

Figure 22. Monthly electricity use and generation of the Concord Foursquare ...............................60

Figure 23. Monthly gas use of the Concord Foursquare ..........................................................60

Figure 24. Parametric energy modeling of the Bedford Farmhouse ................................................62

Figure 25. Electricity use monitoring of the Bedford Farmhouse.................................................62

Figure 26. Gas consumption monitoring of the Bedford Farmhouse................................................6 63

Figure 27. Parametric energy analysis of the Belchertown Cape .....................................................6 65

Figure 28. Electricity consumption of the Belchertown Cape .......................................................6 66

Figure 29. Propane delivery at the Belchertown Cape ..................................................................6 66

Figure 30. Parametric energy modeling of the Somerville Triple Decker ..........................................68

Figure 31. Somerville Triple Decker Electric consumption .............................................................69

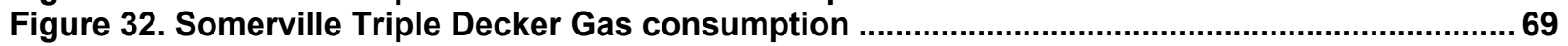

Figure 33. Somerville Triple Decker pre- and post-retrofit source energy breakdown .....................70

Figure 34. Belmont Two Family parametric energy analysis .......................................................... 70

Figure 35. Belmont Two Family post-retrofit gas use ....................................................................... 72

Figure 36. Belmont Two Family post-retrofit electricity use and generation ................................... 72

Figure 37. Parametric energy modeling analysis of the Quincy Bungalow ....................................... 74

Figure 38. Graph of electricity use and PV generation of the Quincy Bungalow..............................75

Figure 39. Graph of natural gas use following the Quincy Bungalow DER …................................... 75

Figure 40. BEopt incremental modeling results for the Millbury Cape .............................................. 77

Figure 41. Pre- and post-retrofit monthly electricity use for the Millbury Cape .............................. 77

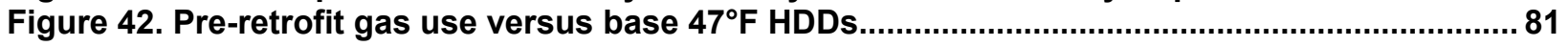

Figure 43. Left: Post-retrofit Millbury Cape; Right: Neighbor's home with ice dams ...................... 85

Unless otherwise noted, all figures were created by BSC. 


\section{List of Tables}

Table 1. Project Overview. 21

Table 2. Floor and Enclosure Areas, Volumes, and Blower Door Results....................................... 49

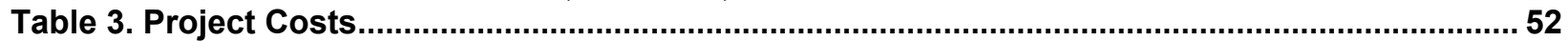

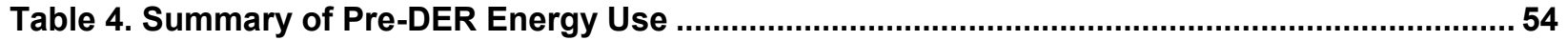

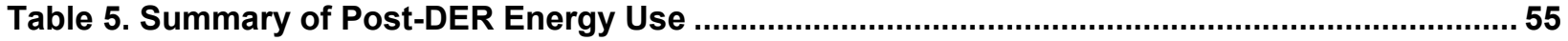

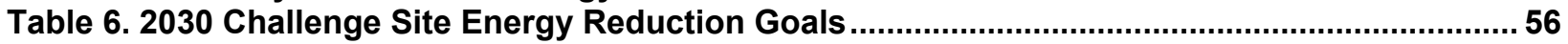

Table 7. Concord Foursquare Pre- and Post-Retrofit Summary .................................................... 58

Table 8. Bedford Farmhouse Pre- and Post-Retrofit Summary......................................................61

Table 9. Belchertown Cape Pre- and Post-Retrofit Modeling Summary ...........................................64

Table 10. Somerville Triple Decker Pre- and Post-Retrofit Modeling Summary ................................67

Table 11. Belmont Two Family Pre- and Post-Retrofit Modeling Summary ........................................ 70

Table 12. Quincy Bungalow Pre- and Post-Retrofit Modeling Summary ......................................... 73

Table 13. Millbury Cape Pre- and Post-Retrofit Modeling Summary .................................................... 76

Table 14. Somerville Triple Decker Weather Calibration Results: Gas and Heating Degree Days... 81

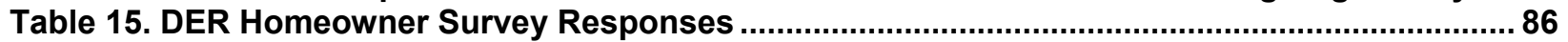

Unless otherwise noted, all tables were created by BSC. 


\section{Definitions}

$\mathrm{ACH} \quad$ Air changes per hour

ACH 50 Air changes per hour at 50 Pascal test pressure

AFUE Annual fuel utilization efficiency

ASHRAE American Society of Heating, Refrigerating and Air-Conditioning Engineers

BA Building America Program

BSC Building Science Corporation

Btu British thermal unit

ccSPF Closed-cell spray polyurethane foam

CDD Cooling degree day

CFL Compact fluorescent lamp

CFM Cubic feet per minute

CFM 50 Cubic feet per minute at 50 Pascal test pressure

DER Deep Energy Retrofit

DHW Domestic hot water

EF Energy factor

$\mathrm{ft}^{2} \quad$ Square foot, square feet

HDD Heating degree day

HfHGL Habitat for Humanity of Greater Lowell

HRV Heat recovery ventilator

HVAC Heat, ventilation, and air conditioning

IMT Inverse Modeling Toolkit

kW kilowatt

PV Photovoltaic

SEER Seasonal energy efficiency ratio

SHGC Solar heat gain coefficient

XPS Extruded polystyrene 


\section{Executive Summary}

Building Science Corporation (BSC) seeks to further the energy efficiency market for cold climate, New England area retrofits by supporting projects based on solid building science fundamentals and verified implementation. The utility company National Grid engaged BSC as a partner to develop guidelines for its Deep Energy Retrofit (DER) pilot program. In addition to guideline development, BSC has acted as a consultant for these projects and others following similar retrofit strategies.

With the high exposure of energy efficiency and retrofit terminology being used in the general media at this time, it is important to have evidence that measures being proposed will in fact benefit the homeowner through a combination of energy savings, improved durability, and occupant comfort. Concrete data from specific projects can close the gap between hype and reality. There are several basic areas of research to which these test homes contribute. These include the approximate energy savings and comfort improvements that can be expected from combinations of retrofit measures, example retrofit costs, and the importance of data collection during the retrofit process.

Seven test homes located in Massachusetts are examined within this report. The homes range in size from $1,868 \mathrm{ft}^{2}$ to $3,484 \mathrm{ft}^{2}$, constructed as early as 1760 and as late as 1953 . Most homes underwent substantial or major renovations along with energy efficiency and durability upgrades. The retrofit strategies of each home are presented and compared, along with the pre- and postretrofit airtightness achieved by the group in relationship to their enclosure areas and volumes. Only two of the homes achieved the stringent National Grid DER goal of testing below 0.1 CFM $50 / \mathrm{ft}^{2}$ of building enclosure. Two other homes came extremely close considering typical margins of error due to testing condition factors such as wind. All of the homes for which pre-retrofit data were available showed significant reductions in air leakage following the retrofit. Four of the homes remained occupied during the retrofit process.

To understand the energy benefit of each retrofit project, utility bills from before and after the retrofit were collected and used to compare energy use. When pre-retrofit utility information was not available, energy models were used to estimate pre-retrofit energy use. The homes discussed in this report have a minimum of seven post-retrofit months of retrofit energy use information available. This was sufficient to cover both warm and cold seasons, and allow extrapolation to estimate whole year energy use to compare to the pre-retrofit state. The homes achieve source energy savings of $23 \%-74 \%$. The homes with PV arrays achieve an additional $11 \%-18 \%$ source energy savings when the amount of electricity generated over a year is subtracted from the amount used by homes.

Costs of each project are presented, with an attempt to isolate the costs of measures specific to DERs and not regular home maintenance and aesthetic upgrades. Finally, occupant feedback from the retrofits is discussed to determine overall satisfaction with the retrofit efforts.

In addition to providing useful project case studies, one of the goals of this report is to explore the importance of and possible strategies for improvement in project data collection. For retrofit projects, a variety of data is necessary to fully understand the improvements achieved by the retrofit, some of which require long-term monitoring. It is too easy to lose track of these details 
during the course of a project, and it can be difficult or impossible to collect these data after the fact. An efficient and easy-to-use database to store these project data is essential to allow the success of a large number of such projects to be easily judged. 


\section{Introduction}

Home retrofits have been targeted as an area of great potential for significant energy savings, employment opportunities, and market growth. However, the barriers to widespread adoption of comprehensive retrofit strategies remain high. Incentive programs such as National Grid's Deep Energy Retrofit (DER) pilot program provide not only financial incentives for these endeavors but specific guidelines to significantly improve energy efficiency while increasing building durability, occupant comfort, and indoor air quality.

\subsection{The Case for Deep Energy Retrofit}

Buildings make up a significant portion of primary energy consumption in the United States (Figure 1). Residential buildings, using $22 \%$ of primary energy, have an even higher impact than does commercial building stock. A significant portion of existing housing stock were constructed prior to the enactment of building energy efficiency codes and without the benefit of energy efficiency measures employed in more recent construction.

\section{End-Use Sector Shares of Total Consumption, 2009}

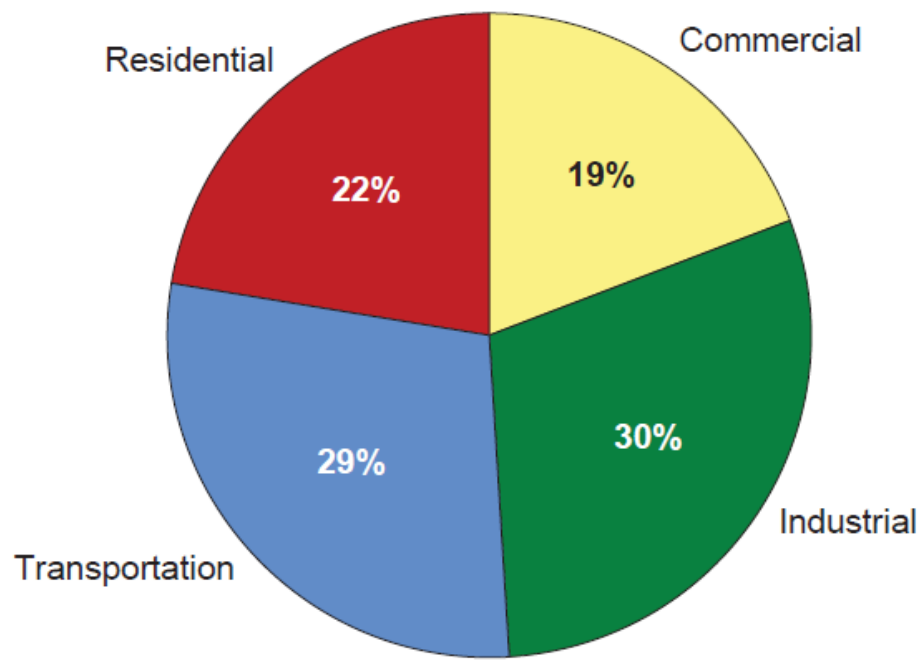

Figure 1. US primary energy consumption by sector

(EIA 2009)

Figure 2 shows the age distribution of housing stock in the United States. Approximately $75 \%$ of existing homes were built before 1990. The impact of successful retrofits of existing homes has the potential to be far greater than that of building new energy-efficient or net zero homes, simply because of the far greater number of existing homes. Serious efforts to reduce energy consumption within the residential sector will need to address energy use of existing homes.

The residential sector is estimated to use about 21 quadrillion Btu of primary energy every year, primarily from burning fossil fuels on site or from fossil fuel-generated electricity (EIA 2009). If it were possible to cut this number in half from a combination of DERs, low-energy new construction, and renewable energy use, this would be the equivalent of removing 263 coal-fired power plants from operation (EIA 2009; Green Power Partnership 2011). 


\section{US Housing: Year Structure Built}

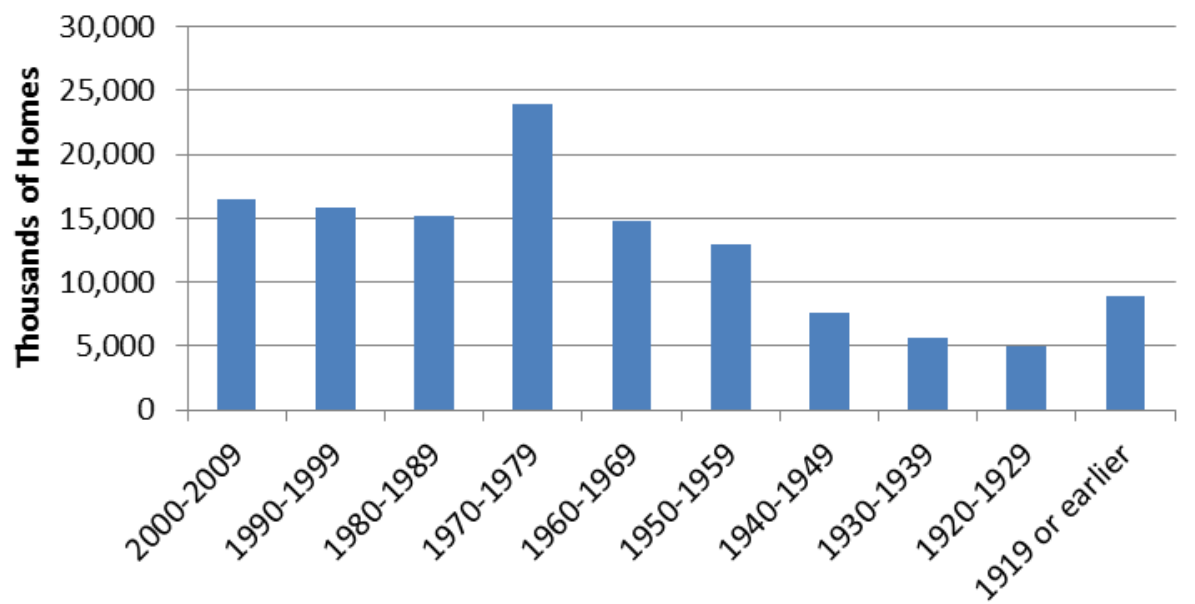

Figure 2. Vintage of U.S. Homes (EIA 2009)

Although the potential energy benefits of widespread retrofit projects are many, it is extremely important to understand the correct way to implement these changes so that durability and indoor air quality problems do not result (BSC 2007). The most important end use in the residential sector is space conditioning. Significantly reducing the space conditioning load of the building radically changes the energy flows through the building enclosure. Changes to energy flows across the building enclosure change the moisture and airflow dynamics within the structure (Figure 3 and Figure 4). And there's where the trouble starts. Without accounting for the changing dynamics brought by aggressive energy conservation measures, these measures risk detrimental impacts to buildings and occupants. Conversely, climate-appropriate measures to improve building durability, comfort, and indoor air quality will likely entail benefits to energy performance when correctly implemented.

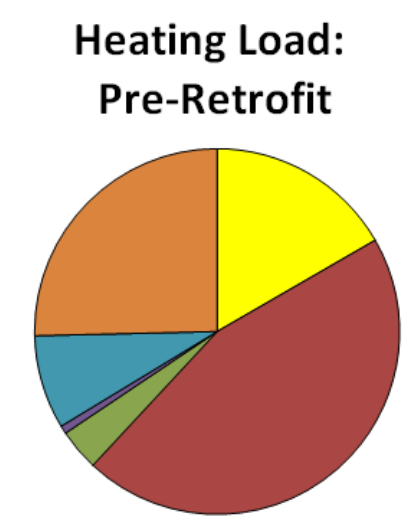

\section{Heating Load: \\ Post-Retrofit}
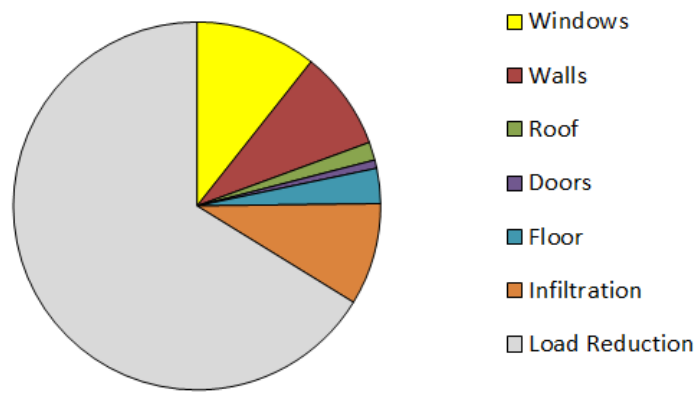

Figure 3. Sample pre- and post-DER heating load components 


\section{Cooling Load:} Pre-Retrofit

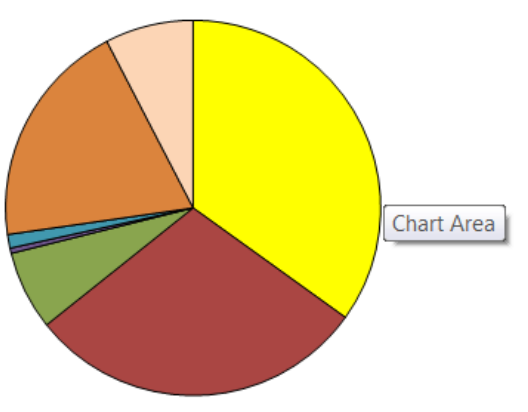

\section{Cooling Load:}

Post-Retrofit

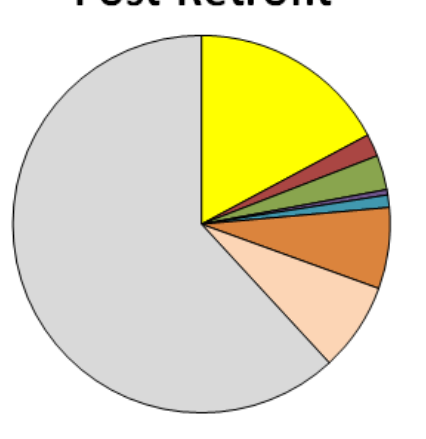

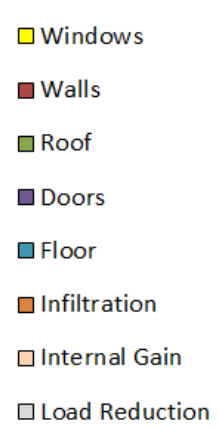

Figure 4. Sample pre- and post-DER cooling load components

\subsection{The Retrofit Challenge}

Although many of the energy efficiency measures for a retrofit are the same as for new construction, the underlying constraints are different. For new construction, the owner has a clean slate for implementing the most important energy-efficient aspects - detailing the air barrier; providing ventilation and distribution for heating and cooling; selecting, installing, and air sealing windows; and providing large amounts of insulation. Energy-efficient heating, ventilation, and air conditioning (HVAC) systems, lighting, and appliances can be selected. As such, these can be implemented following standard, proven details. On the other hand, for a retrofit, the reality of existing conditions results in "special case" details for nearly all portions of the building. The selection of a retrofit implies that there is something about the existing building that needs to be preserved - it may be all or parts of the exterior, it may be all or parts of the interior, it may be just the structural framing, or it may be a combination of the above. This complicates everything - from installing an effective air barrier to providing ventilation in the newly airtightened house.

The test homes in this report represent a variety of typical New England homes in a cold climate (DOE Climate Zone 5a). Although details of the individual existing homes varied, very similar basic techniques were used successfully in the endeavor to upgrade the homes to comfortable, energy-efficient living spaces.

\subsection{The National Grid Pilot Program}

The Recovery through Retrofit Task Force, formed as part of the American Recovery and Reinvestment Act, has identified three major barriers to more widespread adoption of retrofits in the United States. Energy efficiency retrofits for homes have been identified as a key growth area for the U.S. economy, providing jobs for Americans while decreasing fossil fuel energy use. The task force considers the barriers to this growth to be the following:

1. Access to information

2. Access to financing

3. Access to skilled workers.

Various state- and utility-funded home retrofit programs currently exist throughout the United States, some of which receive American Recovery and Reinvestment Act funding. Figure 5 
shows the prevalence of these programs in various states and the approximate number of home retrofits completed under these programs. A number of states have made significant progress in this area, but the overall market penetration is low considering the sheer number of existing homes (Figure 2).

These retrofit programs usually provide information and financial incentives (Barriers 1 and 2) while stimulating the market for skilled workers in related fields (Barrier 3). It is hoped that as the market for these retrofits increases, the availability of skilled labor and consultants will increase as job opportunities in this sector lead to the training and employment of additional skilled workers.

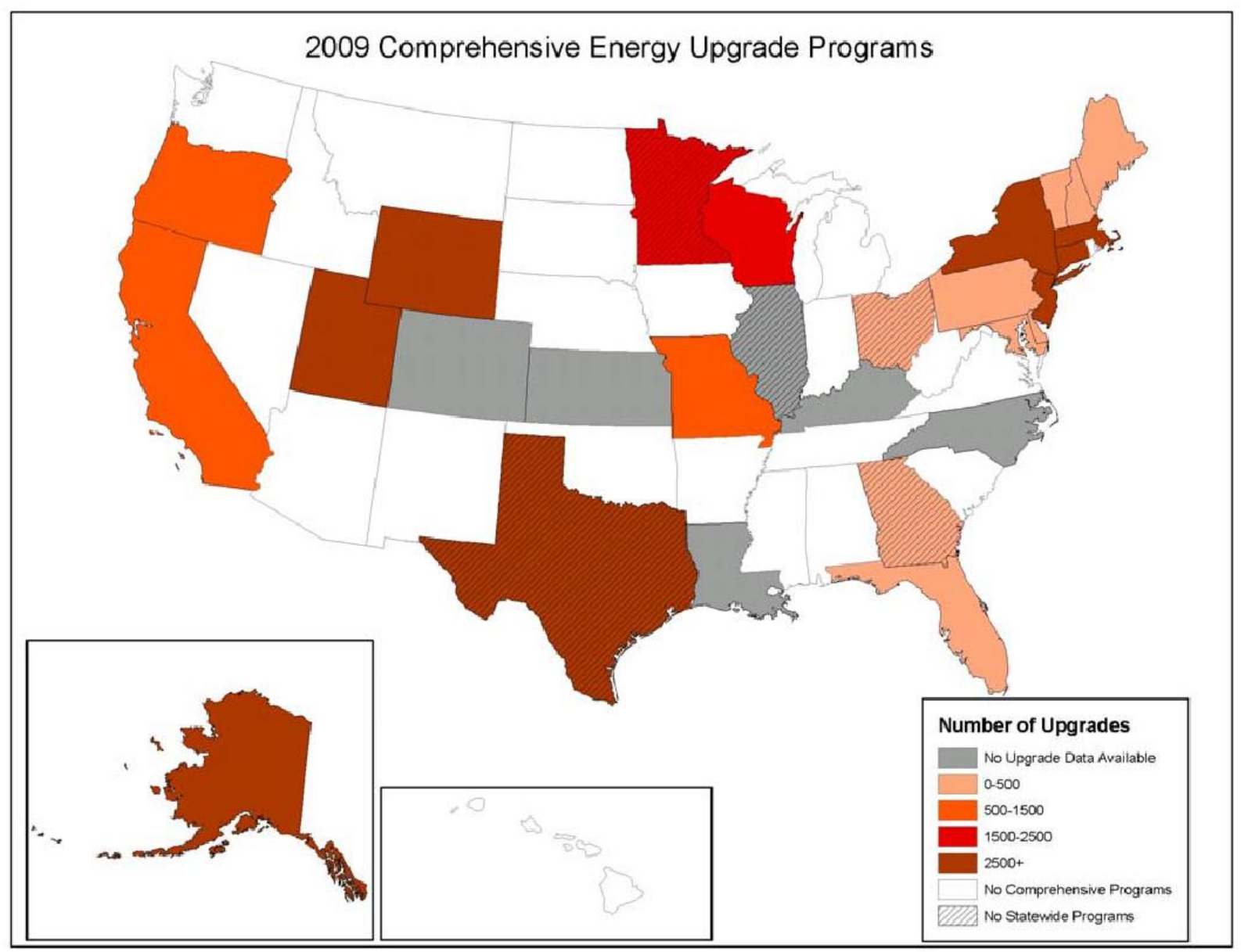

Figure 5. States with comprehensive home energy upgrade programs in 2009.

Source: Navigant Consulting Inc. 2010 (SEE Action 2011)

The National Grid DER pilot program, in which four of the seven homes in this report participate, is one energy efficiency program operating in Massachusetts. However, the scope of National Grid DERs goes significantly beyond those of typical Home Performance programs comprising the majority of those in Figure 5 (SEE Action 2011). Guidelines for the National Grid DER Program were established to provide robust performance and to ensure, as far as possible, that measures would support durability and air quality. This is deemed necessary to avoid detrimental impacts to participating customers as well as to public perceptions. When 
National Grid set out to launch a DER pilot program, it engaged Building Science Corporation (BSC) as a partner to help ensure that radical energy performance improvements also represented technically sound building science practices.

Funding for the National Grid DER Program comes from state-regulated rate payers' "Energy Conservation" and "Renewable Energy" surcharges. Funds are distributed to utilities and segregated between residential and commercial programs, electricity, and gas. Those administering programs are responsible for meeting cost effectiveness metrics for funds spent. As the utility administering the program, National Grid can also administer limited pilot or research initiatives. These initiatives are not subject to the same cost effectiveness metrics, but nonetheless must demonstrate the value to ratepayers of the initiative. The National Grid DER pilot is one such pilot initiative.

Resources brought by a utility-sponsored program enabled a number of customers to pursue extensive retrofits toward the goal of achieving advanced levels of performance. BSC provided the technical guidance to ensure that energy performance measures in these projects are robust and that project teams understand and adequately manage combustion safety, moisture, and air quality risks.

The program requirements for the National Grid pilot address combustion safety, ventilation, and hazardous material mitigation. The program requirements also state that "The project plan and implementation must demonstrate sound building physics as it relates to moisture management of the enclosure and effectiveness of the mechanical system configuration" (National Grid 2011). This provides the program with leverage to pursue proper flashing and effective routing of ventilation distribution, for example. Additionally, combustion equipment needs to be direct vent or forced draft.

The National Grid DER program establishes desired project characteristics for qualification, including fenestration, airtightness, and opaque enclosure guidelines. For reference, their targets for $\mathrm{R}$ values, airtightness, fenestration, and mechanical ventilation are summarized as follows (National Grid 2011):

Insulation - targets for effective R-value: roof-R60, above grade wall -R40, below grade wall - R20, basement floor - R10. Thermal bridging needs to be considered fully in estimation of thermal performance and minimized to the extent possible.

Air Sealing Target - Ideal whole house sealed to achieve 0.1 (zero point 1 ) CFM 50 /sq. ft. of thermal enclosure surface area (6 sides) with high durability materials.

Windows and Doors - target R5 $(\mathrm{U} \leq 0.2)$ whole-unit thermal performance, infiltration resistance performance of $\leq 0.15 \mathrm{CFM} / \mathrm{sq} \mathrm{ft}$. of air leakage, per AAMA11 standard infiltration test...

Ideal whole building ventilation system that is efficient both of fan energy and heat recovery; balanced, distributed, and automatic; All kitchen stoves/ovens should have an exhaust fan vented to the outside fitted with a damper and a capture hood equal to the size of the stove top. Required: easy to control and complies with ASHRAE 62.2. 
Qualification for mechanical system efficiency incentives is decided on a case-by-case basis because of the variety of system options and efficiency ratings. If no HVAC system upgrades are made, atmospherically vented appliances that are to remain must be retrofit with power venting to participate in the program.

The program offers significant financial incentives that are intended to offset a portion of net incremental costs specifically related to energy performance measures. Base incentive limits for one- and two-family dwellings are indexed to conditioned floor area of the building and range from $\$ 35,000$ to $\$ 42,000$ for detached single-family residences and $\$ 50,000$ to $\$ 60,000$ for duplexes. The incentive offered to multifamily buildings of three or more units varies according to the number of units in the building. The base incentive for the three-family building is $\$ 72,000$ and for a building with 10 or more units, the base program incentive is $\$ 106,000$.

Most of the projects participating in the DER pilot involve comprehensive retrofits that treat the entire thermal enclosure and mechanical systems. Some projects participating in the DER pilot are "partial" retrofits that elevate performance of a limited number of components (e.g., abovegrade walls and windows or roof only) to DER levels. The structures are all wood framed with full basement, as is typical for older homes in the region.

As the pilot designation would imply, the program is intended to lay the groundwork for a fullscale utility-sponsored efficiency program. The likely focus of a full-scale program would be specific components retrofit rather than a comprehensive DER. A desired outcome of the pilot is measures guidance and guidance for packages of high performance retrofit measures. An efficiency program supporting high performance retrofit of specific building components has the potential to reach a large population through integration with current distribution channels of products and services for items such as roofing, windows, siding, and basement remodeling.

Three types of field visits are arranged for projects participating in the National Grid DER pilot:

- Pre-work inspection, including blower door testing and assessment of existing conditions - This visit will gather data to supplement data contained in pilot program applications, describing the pre-retrofit conditions. The visits will identify and report pertinent issues not addressed in the application or project plan, and conditions that render aspects of the proposed project plan inappropriate.

- Verification of completed measures in the DER project plan - Site visits will be scheduled to coincide with completion of groups of measures identified in the DER project plan. BSC may conduct inspections at intermediate stages if critical aspects of the project plan, such as implementation of air barrier and drainage measures, do not coincide with stages indicated by program incentive grouping.

- Final inspection, testing - Verify implementation of measures in the DER Project plan. Conduct blower door air leakage testing and, where appropriate, duct leakage testing. Testing will be conducted when all relevant systems are in place and operational. 
Site visits arranged for various stages of each project enable verification of specific measures and assessment of challenges the project faces relative to continuity of air and thermal control, correct arrangement of flashings, and water management features.

Blower door testing is employed to assess the airtightness performance of the building, both before and after the retrofit work.

Four of the seven projects discussed in this report participated in the National Grid DER pilot. The three nonparticipants (the Concord Foursquare, Somerville Triple Decker, and Bedford Farmhouse) were included because retrofit techniques were in line with those advocated by the program. Completed several years ago, the Concord Foursquare and the Bedford Farmhouse retrofits are both considered predecessors to the pilot program.

Two of the homes, the Quincy Bungalow and the Belmont Two Family, are also participating in the Thousand Home Challenge (THC) program. National Grid offers the opportunity to earn an additional $\$ 10,000$ if the stringent post-retrofit THC energy targets are achieved. These targets are customized for each home (ACI 2010). Unlike the National Grid program, post-retrofit performance monitoring is a key component. Homeowners must carefully monitor and budget their energy use to achieve the low energy goals. This occupant participation is likely to result in higher energy savings than if the owners have no specific energy targets after the retrofit is complete. In high performance homes, miscellaneous plug loads, largely dependent on user behavior, make up a much higher percentage of energy use than in a conventional home. 


\section{Retrofit Techniques}

How an existing building is currently functioning may not be understood. But, by virtue of being an existing building, it is functioning. The retrofit will significantly change thermal and moisture dynamics of the structure. Any approach to retrofit must be very sensitive to this fact and minimize the risk of damaging the functions of peoples' homes by inadvertently detracting from durability and indoor air quality. The variety of projects included in this study program yields a variety of approaches.

BSC has conducted previous cold-climate research projects that demonstrated the application of DER techniques to existing wood-frame homes (BSC 2010; Pettit 2009). Each of these retrofit projects employed thick exterior insulation over existing walls and roofs to provide a superinsulated above-grade enclosure.

Ueno (2010) pointed out inherent advantages of the exterior insulation approach to superinsulation retrofit for energy performance and building durability. However, he also noted that exterior insulation can reduce the ability of existing wall systems to dry. Therefore, he concludes, "If an exterior foam retrofit is done, it is vital to ensure that windows and mechanical penetrations are flashed properly."

BSC has found that proper implementation of water management details has not gained a ubiquitous presence in the construction industry - commercial or residential, new construction, or retrofit. In retrofit situations, the implementation of effective water management details is often more complicated than it is in new construction.

\subsection{Roof/Attic Measures}

All of the projects in the sample used an unvented attic approach, as opposed to a vented attic, which is kept outside the thermal enclosure. This approach is popular because it provides more living space or a place to store air handling equipment within the thermal enclosure to prevent undesired heat loss and gain.

Most of these projects used spray foam applied between roof rafters. The spray foam forms the primary airflow control layer for the assembly. One project used netted cellulose insulation and another used unfaced fiberglass batt insulation in place of spray foam.

In most of these homes, foil-faced polyisocyanurate was used on the outside of the roof assembly for additional insulation. In this approach a thick layer of exterior insulation is added above the roof sheathing and under the roof cladding (asphalt shingles) and water control layer (ice and water membrane and roofing felt). This approach also provides insulation to the exterior of the roof structure, resulting in more robust condensation risk management.

An air control membrane consisting of either house wrap or self-adhered ice and water membrane is applied over the existing roof sheathing. Rigid board insulation is applied in two layers. A nail base material (e.g., $1 / 2$-in. plywood) is fastened to the roof framing through the rigid board insulation. The shingles and underlayment are then installed on the nail base per conventional steep roof practice. Insulation as needed to reach the target assembly performance 
value is placed between the rafter framing. Any type of insulation may be used on the inside of the roof sheathing provided the roof is properly detailed to provide robust control of water.

This approach is compatible with roofs that have existing cathedralized ceilings that restrict access to framing cavities or to situations where available space for insulation between and below rafter framing is otherwise limited.

The method is also compatible with the "chain saw" retrofit approach credited to Orr and Dumont (1987). The first step of the "chain saw" approach is to cut off the roof overhangs. This enables the air control and thermal control layers of the roof to be lapped onto and connected directly to the wall system air control layer and thermal control layers. Appropriate overhangs are then added to the finished structure.

\subsection{Above-Grade Wall Measures}

All but one of the projects featured in this report employed a wall assembly consisting of the following:

- Existing $2 \times 4$ frame wall cavities filled with fibrous insulation, blown-in cellulose, or spray foam

- House wrap applied over the existing board sheathing

- 4 in. of polyisocyanurate insulating sheathing, in two 2-in. thick layers, applied over the house wrap; seams of the insulating sheathing staggered, both vertically and horizontally, and the outer layer seams taped

- Vertical wood strapping applied over the insulating sheathing and attached to the wall framing using long screws

- Cladding attached to the wood strapping.

The exterior face of the insulating sheathing is detailed as the primary water control layer for the projects featured in this report. This approach can also be detailed to provide the primary water control behind the insulation at the house wrap or adhered membrane layer over the existing sheathing. The primary airflow control of this wall assembly can be either the exterior face of insulating sheathing or the building house wrap/adhered membrane.

\subsection{Window Measures}

Only three of the seven projects featured in this report achieved the R-5 specified by the National Grid DER program by replacing existing windows with vinyl-framed triple-glazed windows. Homeowners who have recently installed new double-pane windows are often reluctant to replace them with triple-pane options after their investment has been made. However, the double-pane windows selected were reasonably high performance for their class.

Sealant applied around the outer frames of the windows and doors established a connection between the doors and windows and the wall air barrier. BSC recommends that the air seal between the window unit and the rough opening should be toward the interior edge of the window unit frame. There are two reasons for this: 
- At this location, the seal is less likely to interfere with drainage (remember the other building enclosure functions). This is especially important at the sill where the pan flashing must be able to drain to the exterior.

- The remaining gap toward the exterior would be pressure equalized with the exterior. There is then no air pressure difference to drive moisture into the joint (note that water may still be driven into the joint by other forces) (BSC 2009d). Flashing details are another key component of rainwater control for windows (BSC 2009b). In all cases, any water that gets into the window frame must be directed down and out.

\subsection{Foundation Wall and Slab Measures}

It is typical in this region for homes to have full basements, which are often regarded as important usable spaces. Also, for durability of structure and energy performance reasons, it is important to include the basement in the thermal enclosure when feasible (Lstiburek 2006).

All of the projects included foundation wall insulation strategies. Each of these employed either closed-cell spray polyurethane foam (ccSPF) at 2-5-in. thickness or rigid polyisocyanurate to provide insulation, air sealing, and water management at the foundation wall. For all but one home, extruded polystyrene (XPS) rigid insulation was applied either above an existing slab or underneath a new slab and drainage systems were installed below the insulation. Seams and edges of the XPS were taped to provide air flow control.

\subsection{Mechanical System Measures}

Mechanical system upgrades differed among the homes. System selections were influence by such factors as available fuel choices, desire to combine heating with hot water, perceived comfort and convenience, and cost. Ventilation systems were included in all of the home designs; these were heat recovery ventilators (HRVs) with high effectiveness for all but two of the homes; one uses a supply-only system; the other exhausts directly without heat recovery. Although many existing homes do not have ventilation systems, they are essential for indoor air quality in homes achieving the high airtightness goals specified by National Grid and BSC. Most of the homes did not have central air conditioning prior to the retrofit, though some used window units. The addition of both air conditioning and whole-house ventilation increases energy use, but also provides increased comfort to occupants. 


\subsection{Details of Individual Home Retrofits}

This report examines seven homes that undertook similar retrofits in Massachusetts. Their retrofit strategies were based on National Grid and BSC guidelines for DERs meant to achieve significant energy savings (approximately 50\%) from the pre-retrofit state. Table 1 lists the project name, program participation, year the structure was built, and retrofit completion date for each.

Table 1. Project Overview

\begin{tabular}{|c|c|c|c|c|}
\hline Project Name & $\begin{array}{c}\text { Program } \\
\text { Participation }\end{array}$ & Year Built & $\begin{array}{c}\text { Retrofit } \\
\text { Completion } \\
\text { Date }\end{array}$ & $\begin{array}{c}\text { Occupied } \\
\text { During } \\
\text { Retrofit? }\end{array}$ \\
\hline $\begin{array}{l}\text { Concord } \\
\text { Foursquare }\end{array}$ & None & 1915 & December 2007 & Yes \\
\hline $\begin{array}{l}\text { Bedford } \\
\text { Farmhouse }\end{array}$ & $\begin{array}{l}\text { Habitat for } \\
\text { Humanity }\end{array}$ & 1850 & November 2009 & No \\
\hline $\begin{array}{l}\text { Belchertown } \\
\text { Cape }\end{array}$ & $\begin{array}{c}\text { National Grid } \\
\text { DER }\end{array}$ & 1760 & January 2010 & Yes \\
\hline $\begin{array}{c}\text { Somerville } \\
\text { Triple Decker }\end{array}$ & None & 1910 & August 2010 & Yes \\
\hline $\begin{array}{c}\text { Belmont Two } \\
\text { Family }\end{array}$ & $\begin{array}{l}\text { National Grid } \\
\text { DER, Thousand } \\
\text { Home Challenge }\end{array}$ & 1925 & September 2010 & No \\
\hline $\begin{array}{c}\text { Quincy } \\
\text { Bungalow }\end{array}$ & $\begin{array}{l}\text { National Grid } \\
\text { DER, Thousand } \\
\text { Home Challenge }\end{array}$ & 1905 & December 2010 & No \\
\hline Millbury Cape & $\begin{array}{c}\text { National Grid } \\
\text { DER }\end{array}$ & 1953 & October 2010 & Yes \\
\hline
\end{tabular}

The following sections illustrate the enclosure, airtightness, water management, and mechanical system strategies for each of these homes in detail. 


\subsubsection{Concord Foursquare}

Building Type, Style: $\quad$ Sears Roebuck Foursquare

Approx Year Built:

1915

Pre-DER Floor Area:

2,040 $\mathrm{ft}^{2}$ not including basement or attic

Post-DER Floor Area:

$3,600 \mathrm{ft}^{2}$ after conditioning basement and attic

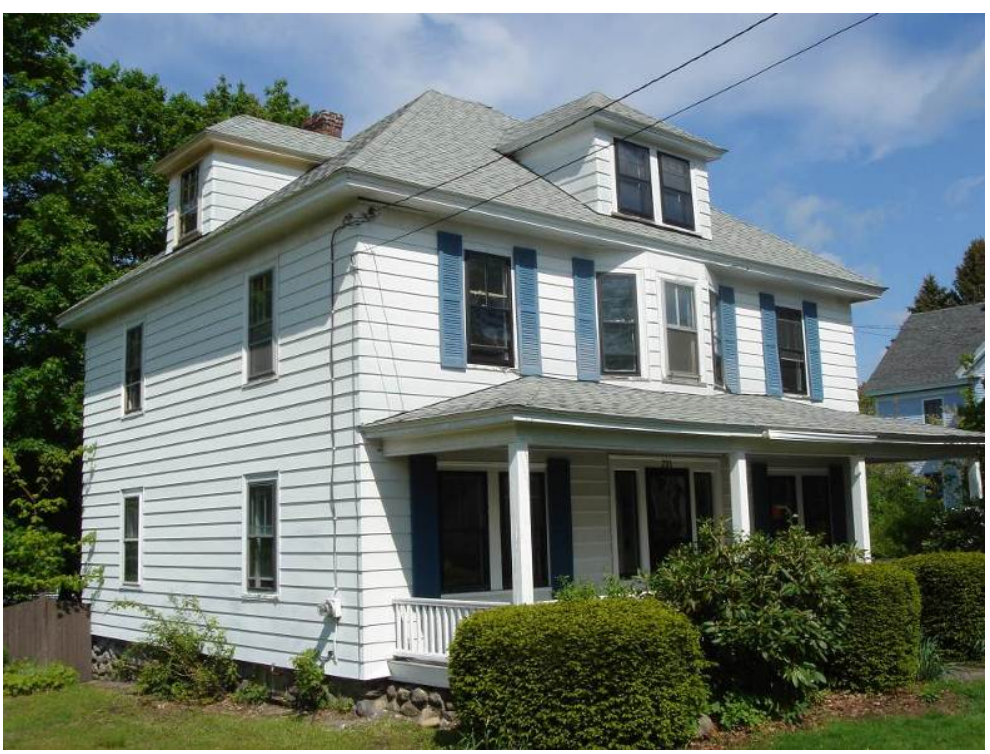

Figure 6. Pre-retrofit Concord Foursquare

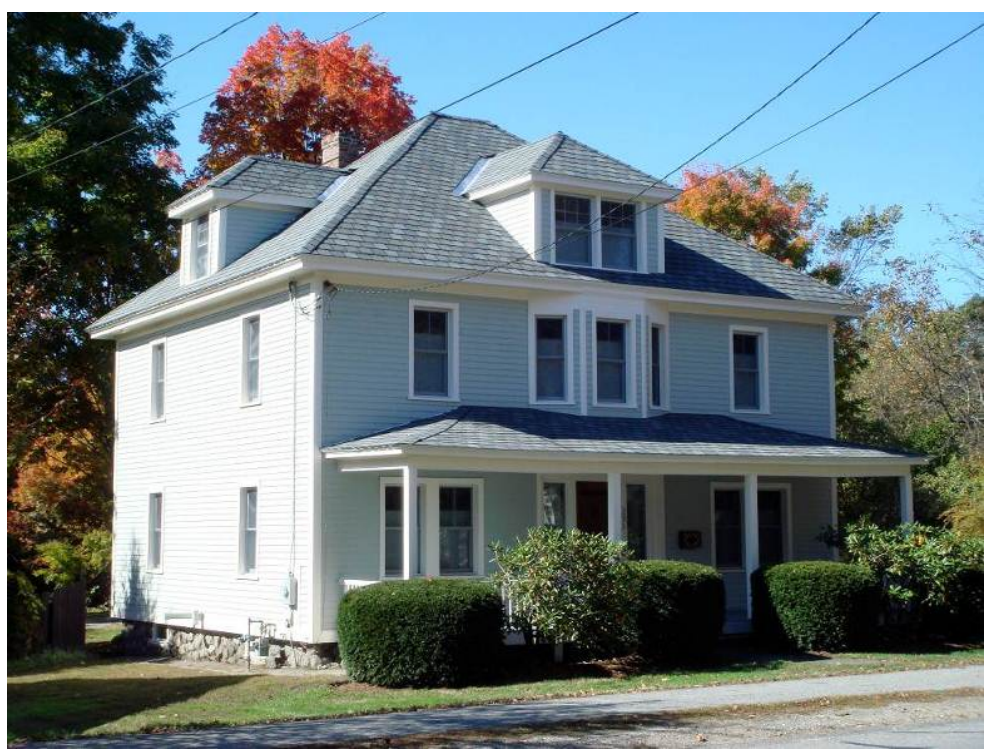

Figure 7. Post-retrofit Concord Foursquare 
The Concord Foursquare is an example of a Sears Roebuck kit home. More than 10,000 of these homes in 15 different styles were built through mail-order kits between 1908 and 1940 . The design is simple to understand and elegant in its efficient enclosure of space.

This 1915 house never had any system upgrades, and still had its original wiring, plumbing, and oil-fired boiler. But it had beautiful plaster, interior wood trim, and maple flooring that were in good shape and ready for another 100 years.

Although the original house enclosed $3,600 \mathrm{ft}^{2}$, only $2,000 \mathrm{ft}^{2}$ were intentionally conditioned. The unconditioned space included $1,000 \mathrm{ft}^{2}$ in the basement and an additional $600 \mathrm{ft}^{2}$ in the vented attic. The bathroom and kitchen, which were in bad shape, were replaced. One of the second-floor bedrooms was changed into a bathroom and laundry room in anticipation of future occupants. Another full bath was added in the now-conditioned attic. In the end, what was a four-bedroom, 1.5-bath house became a four-bedroom, 3.5-bath house with a fully conditioned basement to be used as an exercise and family room. Long-range plans called for four to five occupants.

The project architect and owner of the home is Betsy Pettit, president of BSC. Other BSC employees, including Joseph Lstiburek and Kohta Ueno, acted as project consultants, in cooperation with Synergy Construction and HVAC contractor Jim Finegan.

The home retrofit began immediately after purchase, using standard techniques advocated by BSC and has been monitored by the company for a number of years. The home was occupied during this retrofit period. The retrofit strategy details are presented on the following pages. 


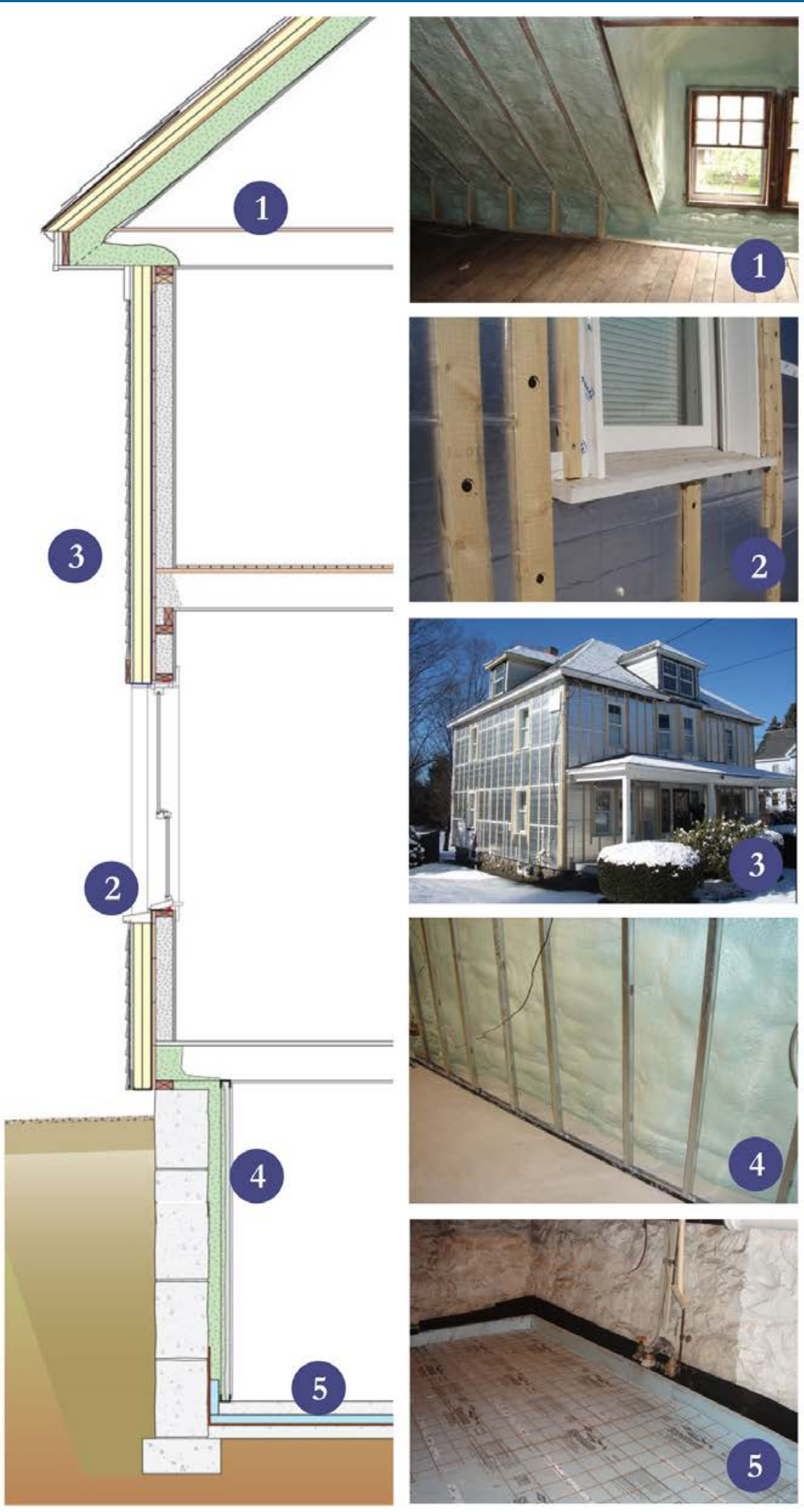

\section{Building EnClosure}

Roof: Unvented

(1) Attic Insulation: R-60 with 4" rigid foam on the exterior and 5 " high density sprayed polyurethane foam to the underside of the roof sheathing

Roof insulation: Two layers of 2" polyisocyanurate rigid insulation

Air Sealing: Airtight drywall approach; low expanding foam sealant around windows, sealants and adhesives used between framing components

2 Window Specifications: Doubleglazed, Low-E, argon-filled: $\mathrm{U}=0.33$, $S H G C=0.33$.

(3Wall Insulation: R-41 with blown cellulose cavity insulation and 4" of rigid foam on the exterior

Foundation: Conditioned basement

(4)Foundation Wall Insulation: R-20 walls with 4" high density sprayed polyurethane foam

5Slab Insulation: R-10; 2" XPS insulating sheathing under the slab

Drainage Plane: Taped foil-faced polyisocyanurate

Radon Protection: Passive system installed

Infiltration: $2.5 \mathrm{in}^{2}$ leakage area per $100 \mathrm{ft}^{2}$ envelope 


\section{Mechanical Design}

(1) Heating: 92\% AFUE sealed combustion gas boiler in conditioned space

(1) 3 Cooling: 13 SEER split system in conditioned space

2 (3) Ventilation: Supplyonly system with outside air to return; run at low speed with an ECM motor

Filter: MERV 13

Return Pathways: Transfer grilles at bedrooms

Ducts: Sheet metal trunk and flex runouts in conditioned space

DHW: 0.8 EF side-arm storage tank

Appliances: ENERGY STAR dishwasher, refrigerator, range, clothes washer, clothes dryer

Lighting: Energy Star CFLs

Site Generated Power: $4.9 \mathrm{~kW}$ PV system 4

\section{Additional Features}

- Large overhangs with crown molding to accommodate additional exterior foam 5

- Front porch

- Maintenance-free fiber cement siding and trim

- Very high efficiency faucets, showerheads and toilets

- Plan minimizes water run-off from the site
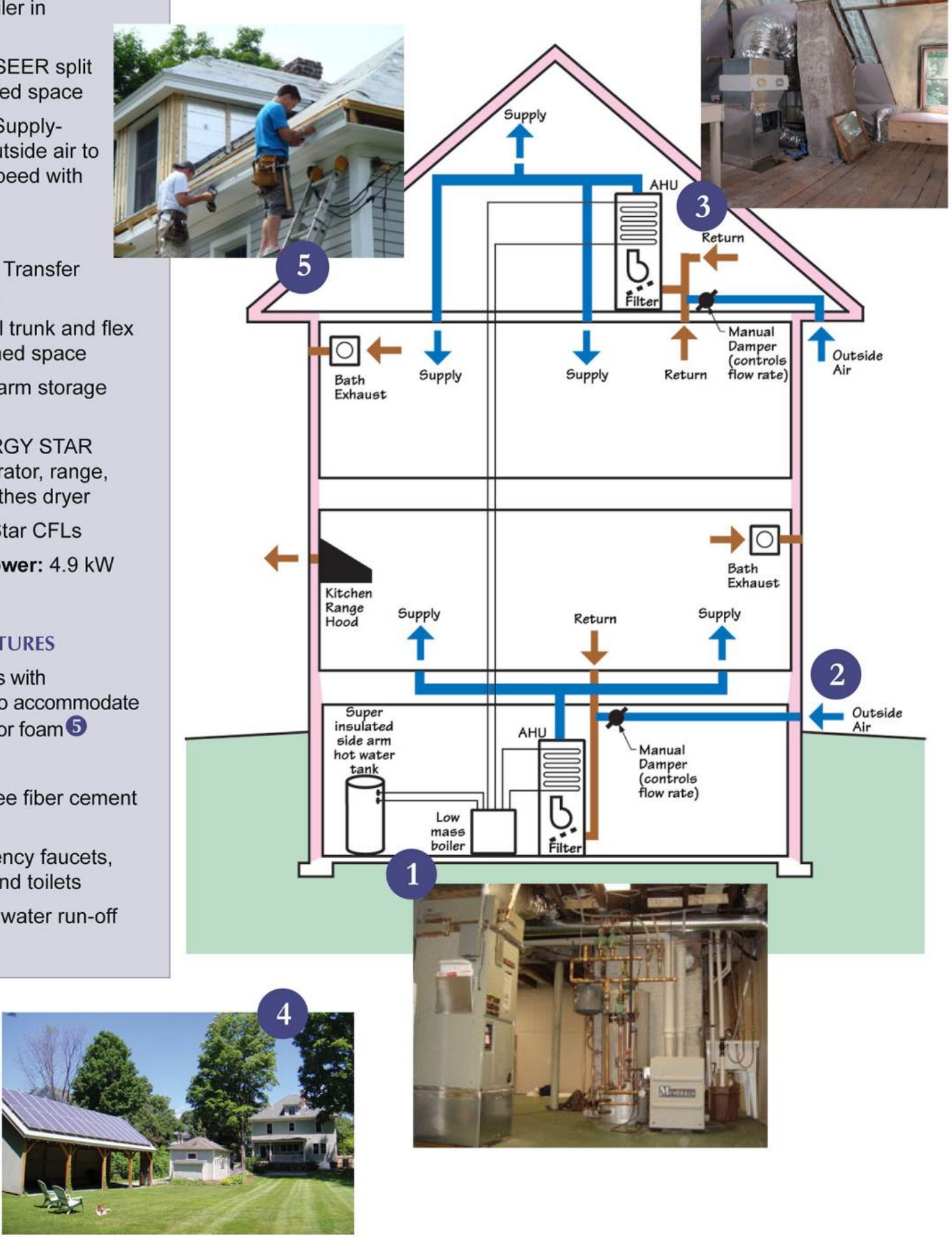


\subsubsection{Bedford Farmhouse}

Building Type, Style: $\quad$ Farmhouse

Approx Year Built:

1850

Pre-DER Floor Area:

2,040 $\mathrm{ft}^{2}$ not including basement or attic

Post-DER Floor Area:

2,308 $\mathrm{ft}^{2}$ including conditioned basement

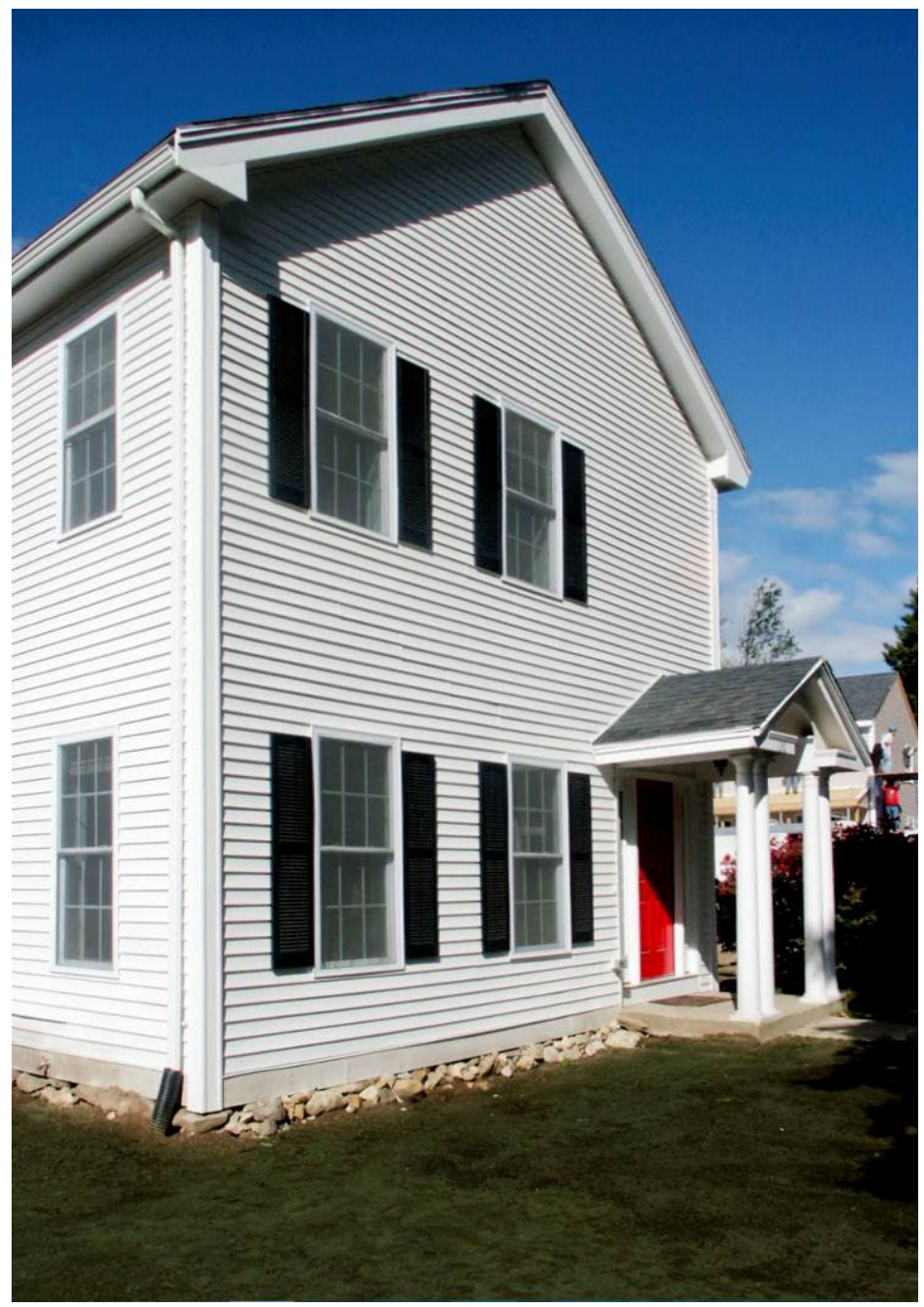

Figure 8. Completed Bedford Farmhouse (Habitat for Humanity)

Habitat for Humanity of Greater Lowell (HfHGL) has partnered with BSC on previous new construction projects. This working relationship continued with HfHGL's renovation of a mid19th century farmhouse into affordable housing meeting Building America (BA) performance standards. BSC guided the project through the compound challenges of implementing high performance construction in the context of Habitat's construction process and in the context of a 150- year-old structure in a historic district. 
BSC applied its 10-20-40-60 insulation performance guideline to the overall project plan. The guideline was met by installing a new insulated slab, applying ccSPF to the interior of the field stone foundation walls, and adding thick exterior insulation to the roof and wall assemblies. BSC developed details to achieve robust water management, maintain air and thermal barrier continuity, and respect the historic character of the property. The exterior of the insulating sheathing was designated to perform both as drainage plane and air barrier for the wall assembly. Comprehensive testing has evaluated the effectiveness of the air barrier system. Utility bill monitoring will provide further assessment of the overall efficacy of the high performance renovation.

The farmhouse had already been altered and adapted many times to suit the changing needs and means of occupants. Some of the additions were poorly constructed and were demolished. The building received new mechanical, plumbing, and electrical systems. The kitchen and bathrooms were entirely remodeled. The interior was modestly reconfigured to accommodate 3 bedrooms and a full bathroom on the second floor, closets for each bedroom, and laundry on the main level. Thermal enclosure improvements brought the attic and basement inside conditioned space.

This project demonstrates massive energy use reductions in a type and age of building that is widespread in the region. The project also demonstrates the application of specific high performance techniques to an older building. By respecting and maintaining the historic character of the building and elevating its aesthetics, the project also allays concerns that a high performance retrofit threatens the character and appeal of a neighborhood. 

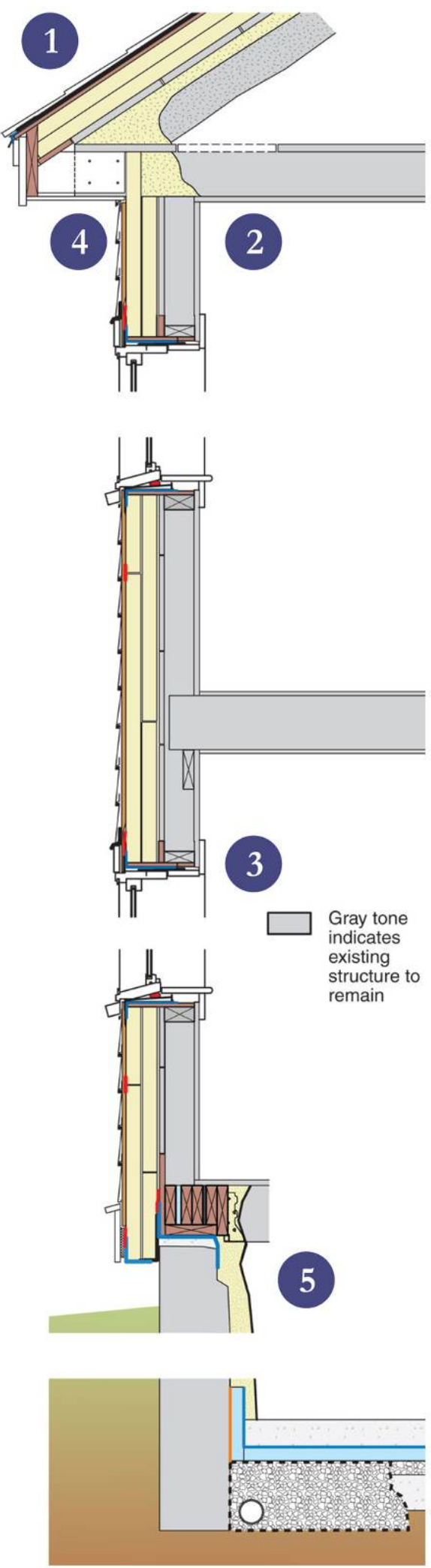
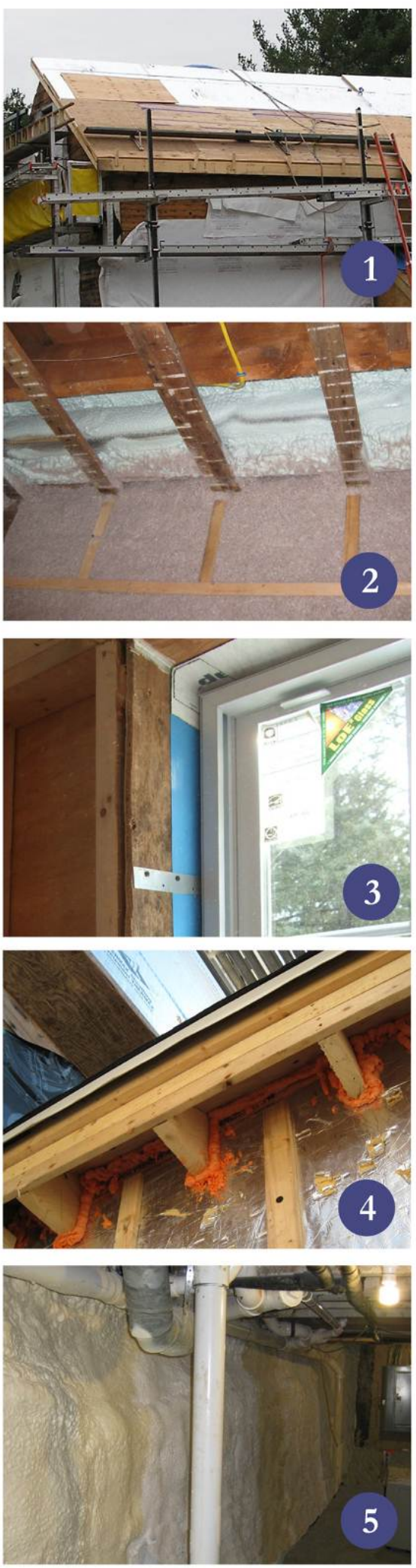

\section{Enclosure Design}

(1) Roof Assembly: Rafterframed unvented attic with R-56 roof insulation: unfaced fiberglass batt insulation (R-30) in rafter bay with two 2" layers of foilfaced polyisocyanurate insulating sheathing (R-26, joints staggered and taped) on top of existing/ repaired roof sheathing.

(2) Wall Assembly: Existing wall framing cavities filled with blown-in cellulose insulation (R-14). Spray foam insulation at critical transitions. Two 2" layers of rigid foil-faced polyisocyanurate insulation (R-26)

\section{Window Specifications:}

Andersen Silverline double glazed, Low-E, vinyl windows: $\mathrm{U}=0.35$, $\mathrm{SHGC}=0.29$

(4) Air Sealing: The primary air flow control layer is the exterior face of the insulating sheathing with taped seams. Self-adhered membrane and low expansion foam sealants transition the air flow control at windows. Self-adhered ice/water membrane over the entire surface of the roof sheathing provides air flow control at the roof. Low expansion foam is used to transition the air barrier to roof framing and sheathing. Self-adhered membrane flashings transition the air control layer at the base of the above grade wall to the closed-cell foam applied to the interior of the foundation walls.

\section{Foundation Assembly:}

Conditioned basement with 2-3" closed-cell spray foam insulation applied directly to field stone foundation walls and covered with FireFree $88^{\circledR}$ ignition barrier paint. A 12 " high strip of 2" XPS as the slab perimeter thermal break also allows foundation walls to drain to the sub-slab drainage system. Trenches filled with gravel and drainage pipe connected to a sump manage bulk water below a new concrete basement floor slab, 6 mil poly, 2" XPS and continuous bed of gravel. 


\section{Mechanical Design}

1) Heating: 96\% AFUE sealedcombustion gas furnace with a MERV 13 filter. Furnace installed in conditioned space.

2 Ventilation: Central-fanintegrated supply (CFIS) ventilation with Aprilaire controller.

\section{(3) Space Conditioning}

Distribution: Air handler and distribution entirely within conditioned space. Sheet metal trunks and run-outs. Ducted return from first floor with transfer grilles above bedroom doors.

(4) DHW: 0.82 EF on demand gas water heater

\section{Lighting: 90\% ENERGY} STAR $^{\circledast}$ CFLS

6 Appliances: ENERGY STAR ${ }^{\circledR}$ dishwasher, refrigerator and clothes washer
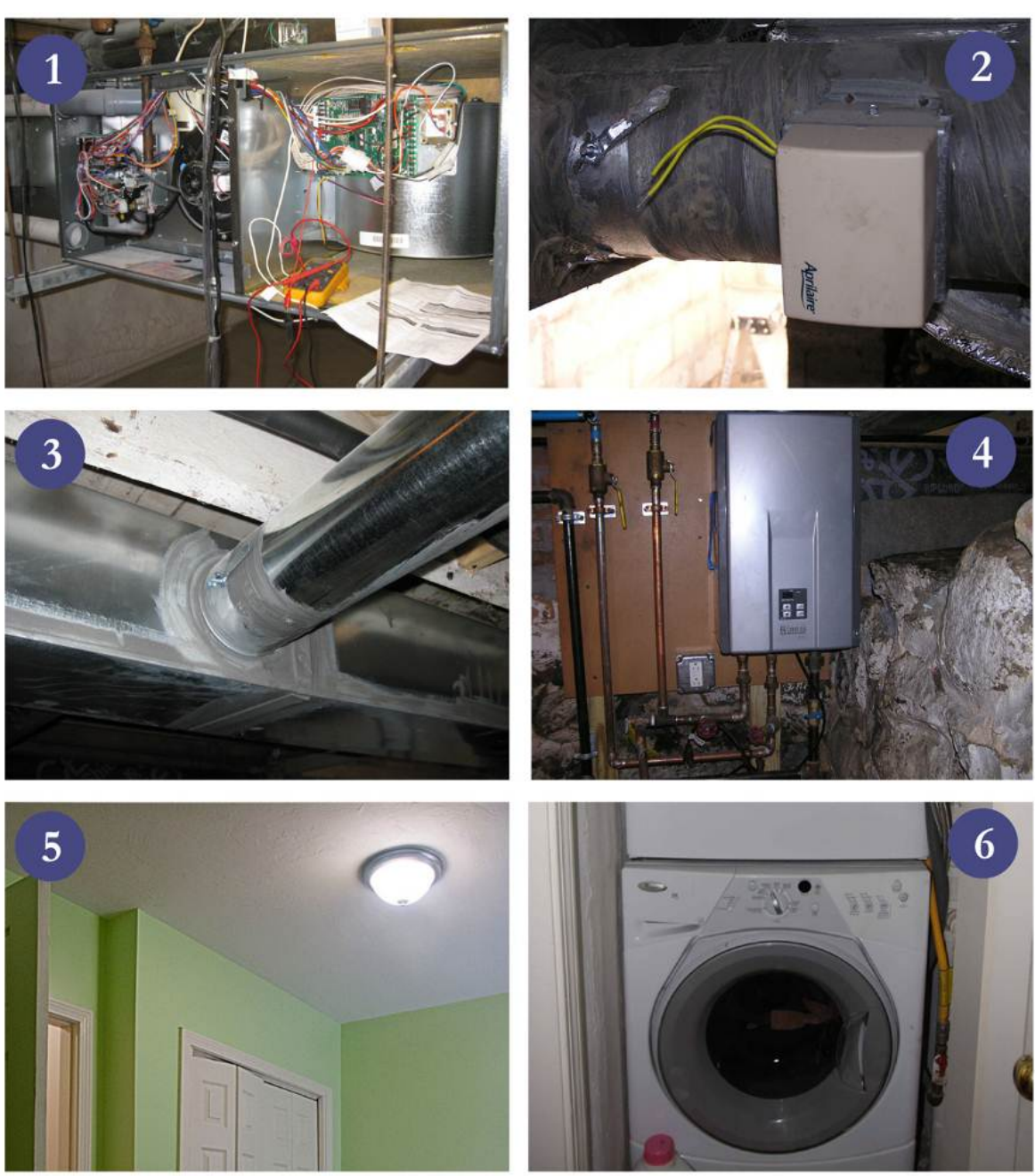


\subsubsection{Belchertown Cape}

Building Type, Style: $\quad$ Cape

Approx Year Built: $\quad 1760$

Pre-DER Floor Area: $\quad 1,435 \mathrm{ft}^{2}$ excluding unconditioned basement

Post-DER Floor Area: $\quad 1,907 \mathrm{ft}^{2}$ after including basement

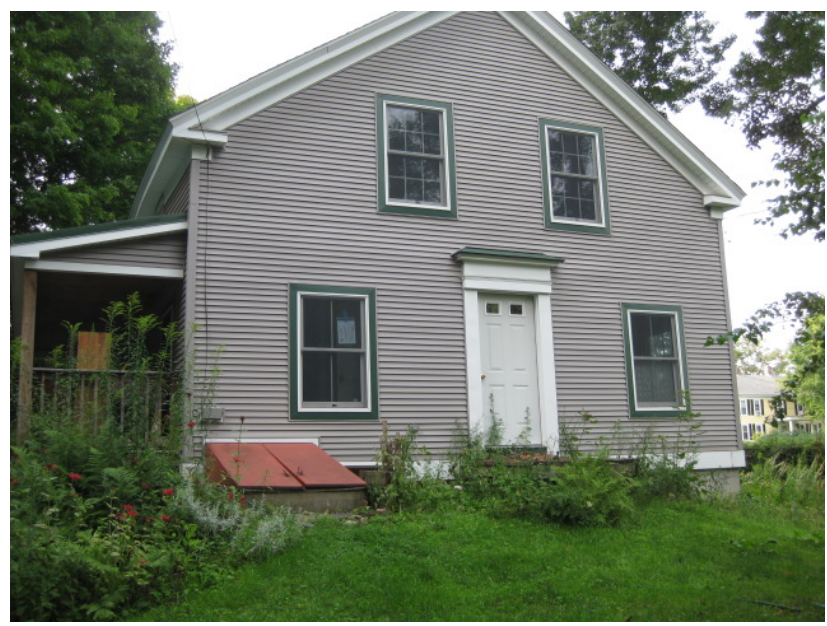

Figure 9. Pre-retrofit Belchertown Cape

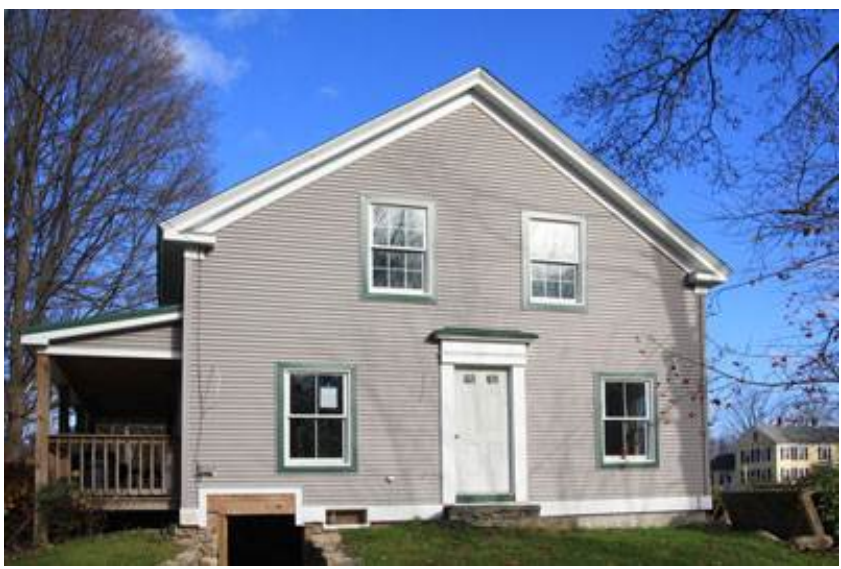

Figure 10. Post-retrofit Belchertown Cape

January 2010 saw the completion of the first project participating in the National Grid DER pilot. This project involved the renovation of an 18th century Cape (Figure 9). The owners and builder had already planned a comprehensive renovation, so financial and technical support from National Grid and BSC, respectively, enabled this project to achieve a super-insulated enclosure ( $\sim$ R-35 walls, R-50+ roof, R-20+ foundation), extensive water management improvements, high efficiency heating and water heater, and state-of-the-art ventilation. Air leakage testing found the enclosure and the new duct system to be very airtight, measured at 468 CFM 50 or $1.9 \mathrm{ACH} 50$. 
Prior to the retrofit, this largely uninsulated 18th century Cape offered little in the way of thermal comfort and exhibited a lack of proper water management. A pre-retrofit blower door test of this $1,400 \mathrm{ft}^{2}$ home measured $9079 \mathrm{CFM} 50$, or $57.7 \mathrm{ACH} 50$. The house used approximately 7 cords of wood per year and the owners reporting living in the room with the wood stove during the winter while allowing other parts of the house to drop below freezing temperatures. Standing water was observed in the basement prior to the retrofit. Windows had been replaced relatively recently with double-glazed, low-e, wood-framed units, but unfortunately, these had been installed without any flashing or air sealing.

As an alternate to the already comprehensive renovation planned, the builder offered a high performance package to meet the objectives of the National Grid DER pilot. This package included extensive use of medium-density spray foam insulation and construction of a $2 \times 4$ stud wall to the interior of existing exterior walls to accommodate a greater thickness of foam.

BSC expressed concern that adding a thick layer of air-impermeable, vapor-retarding insulation to the interior without ensuring proper water management on the outside would put this 250year-old structure at risk. BSC called for remedial flashing at windows and inspection of other flashing details. Inspection of water management details revealed numerous problems that necessitated installation of new flashings and corrections to the drainage plane.

The initial renovation plans had already envisioned significant trenching, piping, and gravel in the basement to control the obvious water problems. The DER plan added insulation to the walls and an insulated slab.

The owners and builder were disinclined to replace functioning and relatively new windows in order to achieve what was perceived to be a modest gain in thermal performance. The owner and builder proposed a number of strategies to improve the thermal performance of the existing windows. Analysis by BSC found that high quality exterior storm windows offered the best combination of improved thermal performance, interior surface condensation control, and exterior rain shielding for the windows.

After some discussion and analysis by BSC, the builder elected to include the small attic space within the thermal enclosure. This allowed for the new ducted heating distribution system to be entirely contained within the thermal enclosure. This home remained occupied during the retrofit process.

The following pages show the details of the enclosure and mechanical system upgrades. 

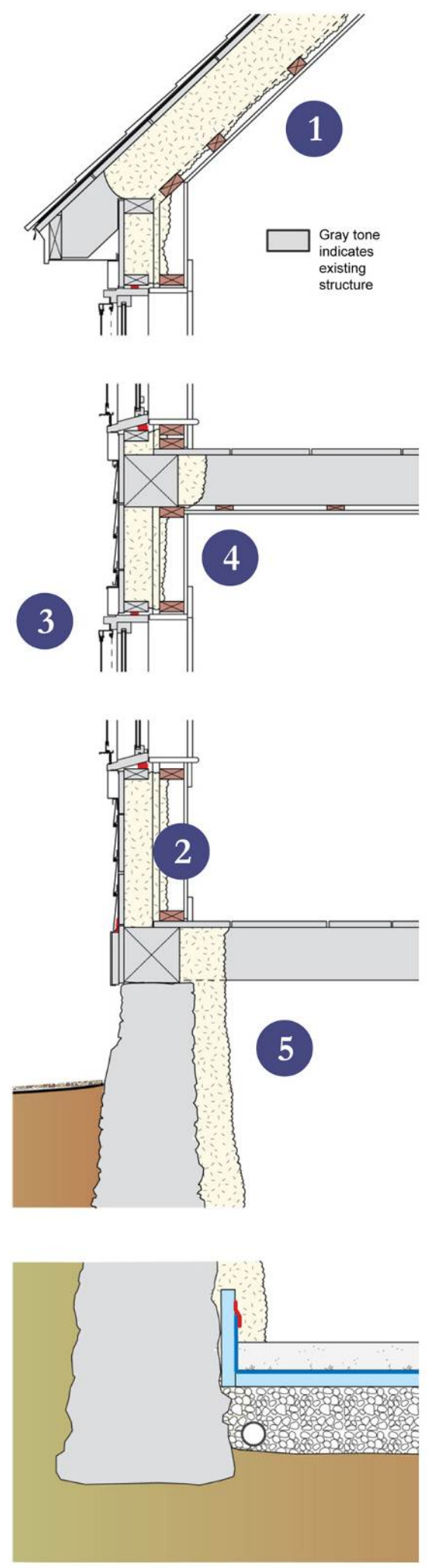
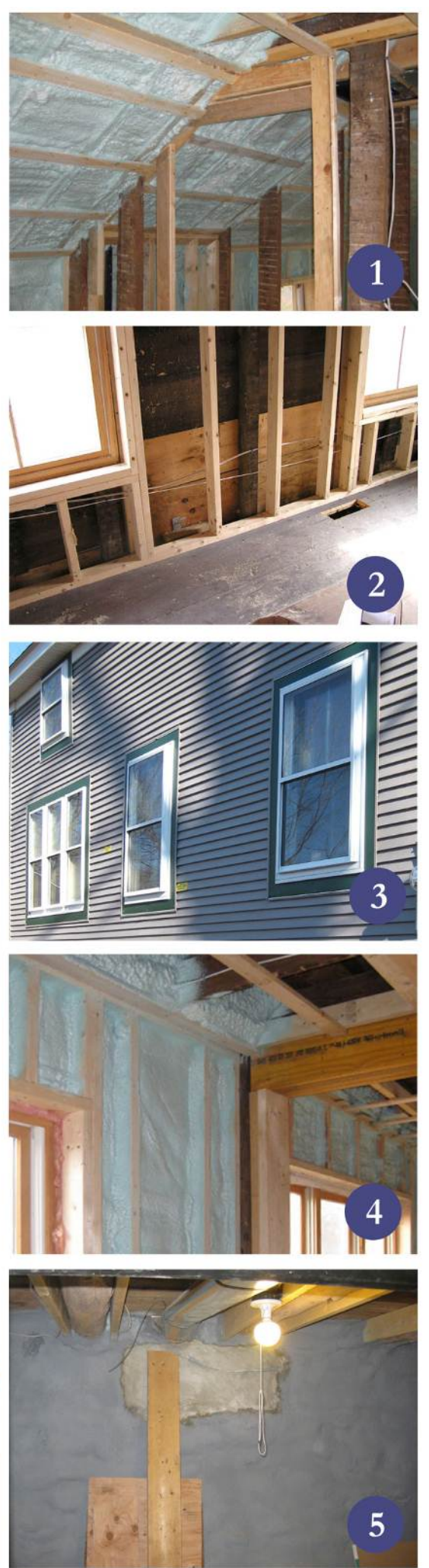

\section{Enclosure Design}

(1) Roof Assembly: Compact (unvented) roof assembly with existing $2 \times 8$ rafter framing and $2 \times 3$ cross furring, framing cavity and portion of furring cavity filled with R-56 Demilec Heatlok Soy ${ }^{\mathrm{TM}}$ medium density spray foam insulation.

(2) Wall Assembly: $2 x 4$ stud wall constructed to inside of original post and beam frame with 1" gap between existing and new framing. R-32 ( 5") medium density spray foam insulation sprayed into wall cavities and over rim beam.

(3) Window Specifications: New Harvey Tru Channel storm windows over existing wood-framed, doubleglazed, low-E windows; approx. composite performance: $\mathrm{U}=0.25$, $\mathrm{SHGC}=0.52$.

(4) Air Sealing: Continuous layer of medium density, closed-cell spray foam insulation provides air flow control in the field of the wall and roof assemblies. Spray foam insulation also applied at rim beams and in a floor assembly over a crawl space. Low-expansion foam sealant applied around windows and doors, and at any mechanical or electrical penetrations through the enclosure.

5Foundation Assembly:

Conditioned basement with 3-5" medium density spray foam insulation applied directly to field stone and concrete foundation walls. Spray foam insulation painted with Blaze Lok $1 \mathrm{~B}^{\mathrm{TM}}$ ignition barrier paint. A 12" high strip of 2" XPS as the slab perimeter thermal break also allows foundation walls to drain to the sub-slab drainage system. Several trenches with drainage pipe connected to drain and filled with gravel manage bulk water. New cast concrete basement floor slab over 6 mil poly, 2" XPS and continuous bed of gravel. 


\section{Mechanical Design}

(1) Heating: $96.7 \%$ AFUE sealed combustion propane furnace in conditioned space. High SEER coil installed for future connection to airsource heat pump.

(2) Ventilation: High efficiency heat recovery ventilator (HRV) with dual ECM motors and $74 \%$ recovery efficiency. Outside air supply ducted to heating system distribution, exhaust air taken from bathroom.

\section{(3) Space Conditioning}

Distribution: Insulated sheet metal trunks with insulated flex run-outs. Ducted return in each bedroom plus two additional returns in first floor areas. Entire distribution system within thermal enclosure.

(4) DHW: $0.86 \mathrm{EF}$ on-demand propane-fired water heater.

5Lighting: Hard wired ENERGY STAR®CFL lighting plus high efficacy (60 lumen/Watt) LED lighting.

6 Appliances: ENERGY STAR ${ }^{\circledR}$ dishwasher, refrigerator and clothes washer.
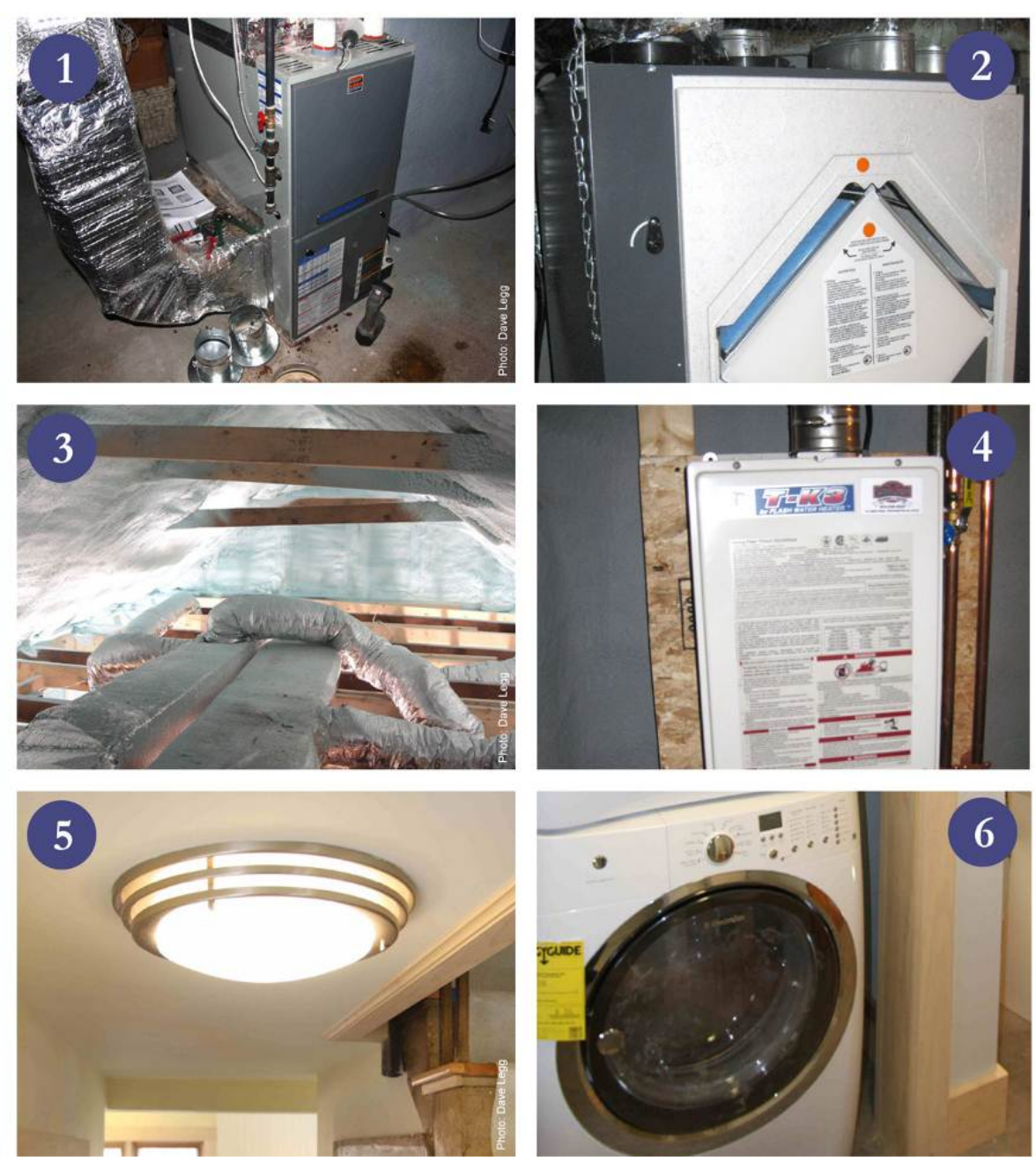


\subsubsection{Somerville Triple Decker}

Building Type, Style: $\quad$ Three-Family Triple Decker

Approx Year Built:

1910

Pre-DER Floor Area:

$3,120 \mathrm{ft}^{2}$ excluding unconditioned basement

Post-DER Floor Area:

$4,160 \mathrm{ft}^{2}$ after including basement
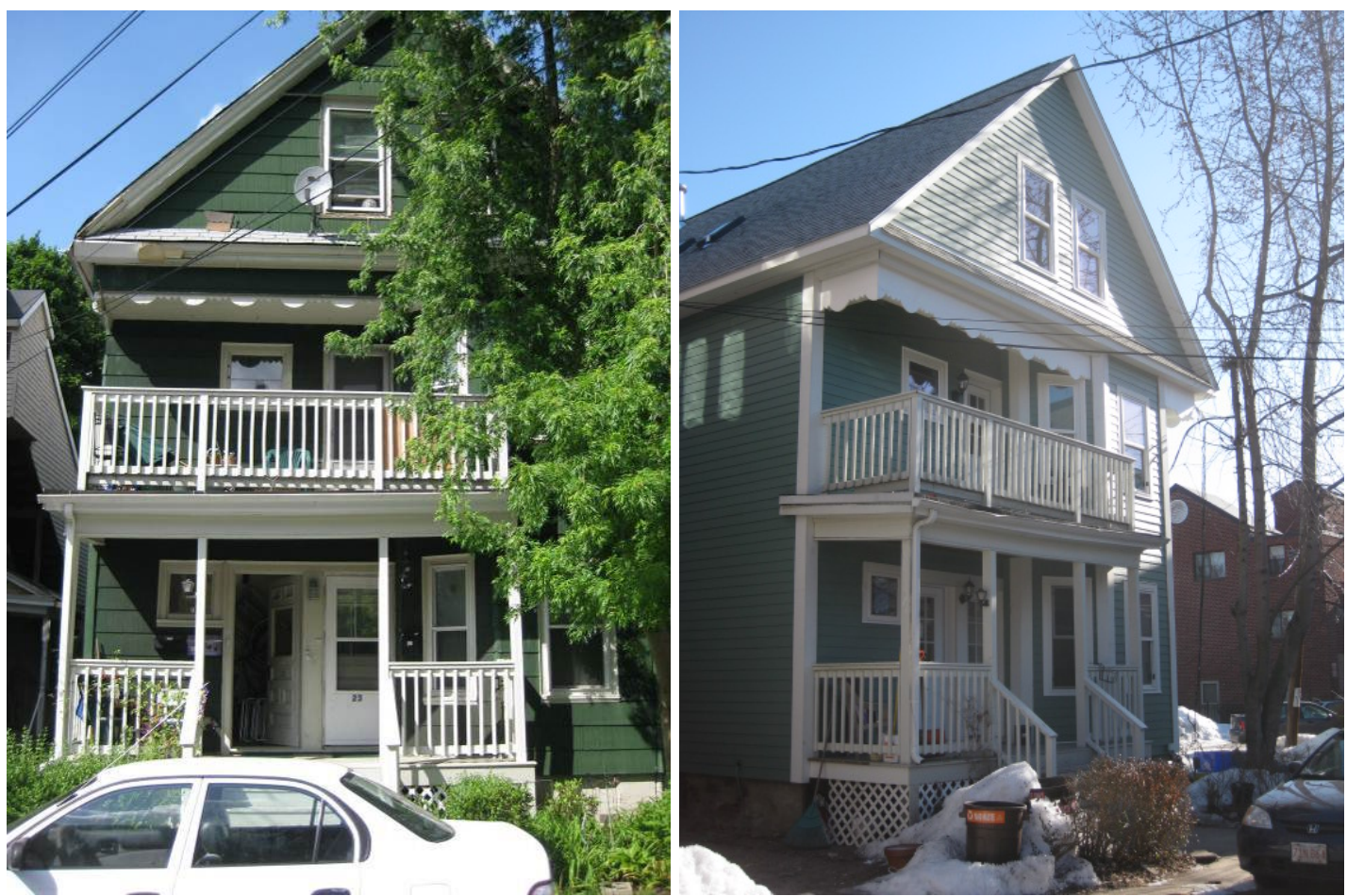

Figure 11. Pre-(left) and post (right) retrofit triple decker located in Somerville, Massachusetts

The Somerville Triple Decker is a triple-decker multifamily wood-framed building typical of New England, circa 1920. Thousands of these homes were built to house new immigrants and other workers in the early 1900s, efficiently sharing the cost of land, roofing, and foundation among the occupants (Irving 2011). These homes are frequently owned by one occupant and rented to others, sometimes to extended family. These aging original New England triple deckers will continue to need renovations for which this Somerville test home may serve as an example.

Working with Synergy Construction and BSC, architectural designer Laura Catanzaro of Holistic Design and Space Planning acted as a consultant and project manager for the efforts. The home remained occupied by all three of the resident families during the retrofit process.

The following pages show the details of the enclosure upgrades. Walls were previously uninsulated. The final decision was to insulate the basement walls (including the basement in the conditioned space) rather than the basement ceiling (excluding the basement). Given the plumbing and ductwork that penetrates the basement ceiling, it was recognized that creating an airtight seal at the ceiling would be very difficult. In addition, because they were retaining 
existing plumbing pipes, there was concern that fixing any of these pipes in the future would be require cutting out of the ceiling insulation. However, the basement floor was not insulated, against BSC recommendations of insulating slabs to a nominal R-10. For a retrofit, this particular measure can be problematic because adding 2 in. of insulation to the floor raises the floor elevation, typically resulting in a ceiling height problem. It also can seem unnecessary to the homeowner, as the ground temperature at that level is moderate, and therefore the energy loss through the floor is relatively low. However, an untreated basement floor can be a source of moisture from condensation and possible capillary wicking from below (BSC 2009f). Although the recommended slab insulation was not included, water management and soil gas venting measures were added.

The following pages show the details of the enclosure and mechanical system upgrades. 

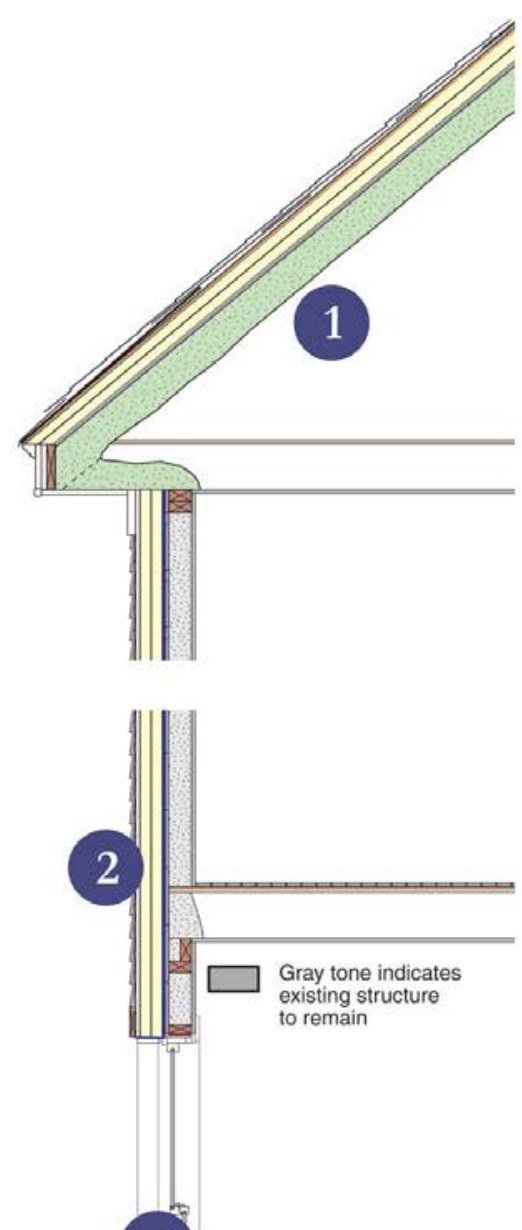

3

4
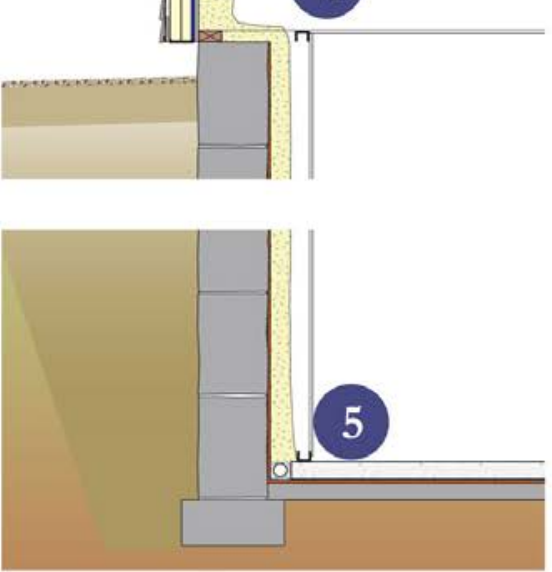
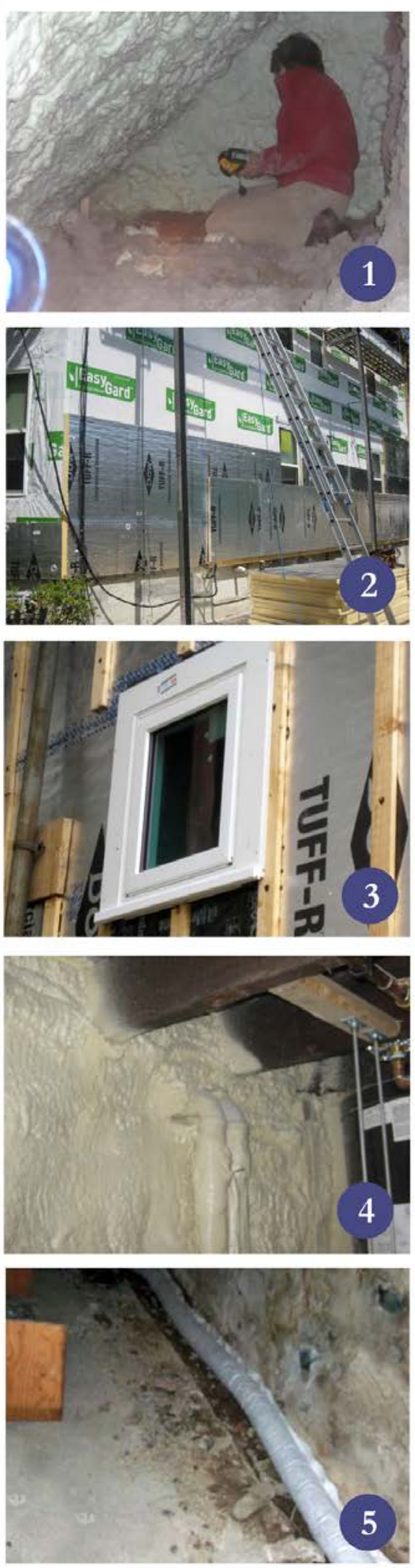

\section{Enclosure Design}

(1) Roof Assembly: R-55 with 8 " open-cell spray foam on the underside of the roof deck filling rafter bays; two layers of 2 " foilfaced polyisocyanurate rigid insulation over existing roof sheathing with joints staggered and taped.

2Wall Assembly: R-41 with blown cellulose cavity insulation and 4" of foil-faced polyisocyanurate rigid insulation.

\section{(3) Window Specifications:}

New Serious Materials fiberglass insulated glass units with suspended film; $U=0.19$, SHGC $=0.24$.

\section{(4) Infiltration: Taped roofing} membrane; housewrap on above grade walls; closed-cell spray faom on foundation walls; $3.5 \mathrm{ACH} 50 \mathrm{~Pa}$.

\section{(5)Foundation Assembly:}

Uninsulated slab; perimeter subslab drainage and passive soil gas system added; R-20 walls with 4" high density sprayed polyurethane foam. 


\subsubsection{Belmont Two Family}

Building Type, Style: $\quad$ Two Family

Approx Year Built:

1925

Pre-DER Floor Area: $\quad 3,417 \mathrm{ft}^{2}$ excluding unconditioned basement

Post-DER Floor Area: $\quad 4,768 \mathrm{ft}^{2}$ after including basement

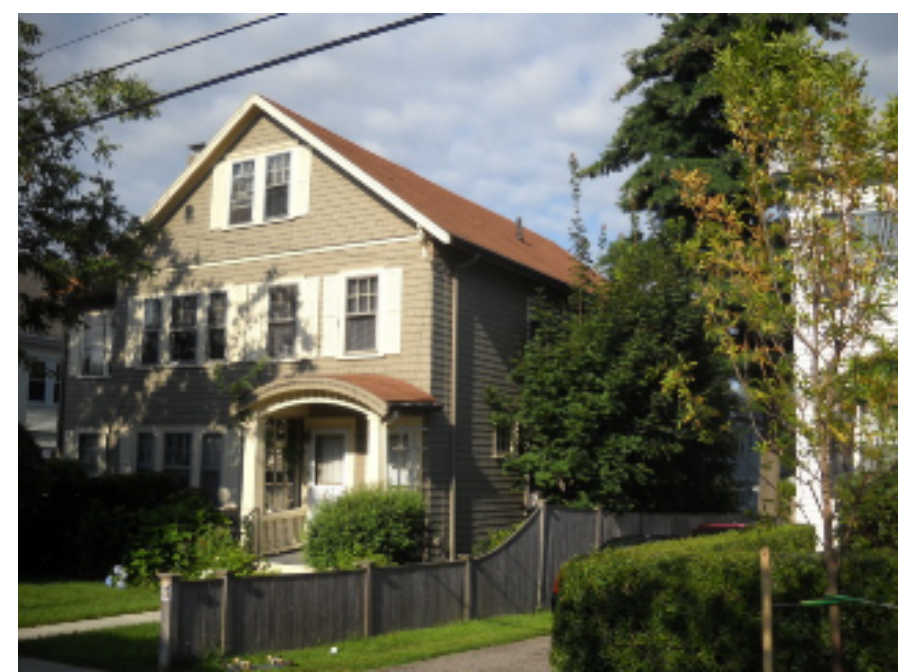

Figure 12. The pre-retrofit Belmont Two Family

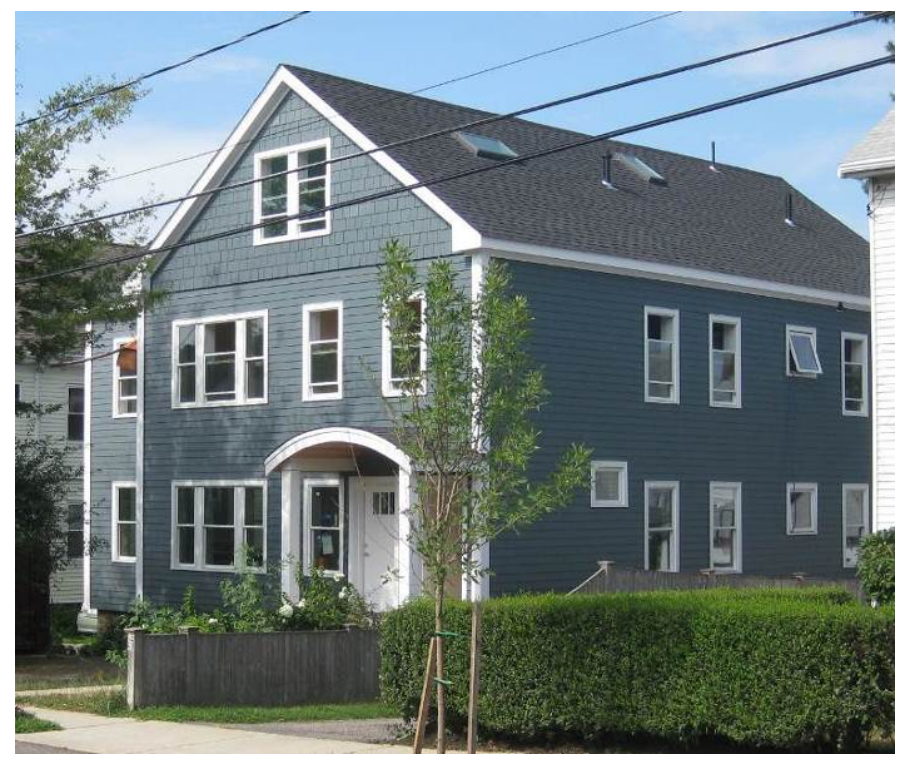

Figure 13. The post-retrofit Belmont Two Family

September 2010 saw the completion of the second project participating in National Grid's DER pilot program, a two-family home located in Belmont, Massachusetts. As the technical team in 
this pilot program, BSC supports the projects by evaluating and approving project plans, providing technical support, and performing site visits for verification of measures and testing. The project contractor was Byggmeister, Inc.; the DEAP Energy Group acted as an additional design consultant.

This project involved an extensive interior and exterior renovation of an uninsulated two-family home built in 1925. The work for this retrofit was significant, but it restored the original charm of the interior and exterior of the residence and dramatically reduced energy demands. Energysaving improvements for the project included a super-insulated enclosure, high performance windows, high efficiency heating and cooling, solar water heating, and mechanical ventilation. With support from the National Grid DER program, insulation levels were increased and the project was improved in many details with rigorous peer review and supervision.

The renovation plan included a conditioned shared basement, a finished third floor to be part of the upper unit, and upgrades throughout both units. The home was purchased before the retrofit but remained unoccupied until complete.

The overall retrofit strategy for the enclosure for this project was to literally wrap the abovegrade portion of the house in a continuous and sealed layer of insulation. As part of the National Grid DER pilot project, the goals for the thermal performance of the enclosure were R-40 for the exterior walls and R-60 for the roof. These targets were met by covering the existing board sheathing of the walls and roof with multiple layers of foil-faced polyisocyanurate insulating sheathing and by blowing cellulose insulation into the previously uninsulated wall and rafter bays. To accommodate the wrapping of the insulation from the wall to the roof, the existing rafter tails were sawed off. New eave and rake overhangs were built and attached to the building structure through the insulating sheathing. All windows were replaced with triple-glazed windows located in the outer plane of the retrofit wall assembly.

With exposed stone foundation walls, the existing basement was cold, damp, and subject to minor flooding. A subslab interior perimeter drainage system connected to a sump pump was installed for water management. Because the basement was to contain mechanical equipment and some finished space, it was included within the thermal enclosure. High-density ccSPF was applied to the interior side of the foundation walls and covered by a steel stud-framed partition wall with mineral wool insulation. However, the basement slab was not insulated in order to preserve head height. As a compromise that would address some of the moisture-related issues, an application of moisture control epoxy coating was applied over the slab. In addition, the basement conditions are being monitored to determine if a dehumidifier is needed there.

The existing oil boiler steam heat system was replaced with a new energy-efficient forced-air system with cooling and gas heating. The decision to change to forced air required installation of ductwork for air distribution. This was not a major obstacle because much of the interior was being opened up for renovation. Also, as a two-family building, ductwork for the lower unit could be primarily in the basement and ductwork for the upper unit could be added as the attic was being finished.

The following pages show the details of the enclosure and mechanical system upgrades. 

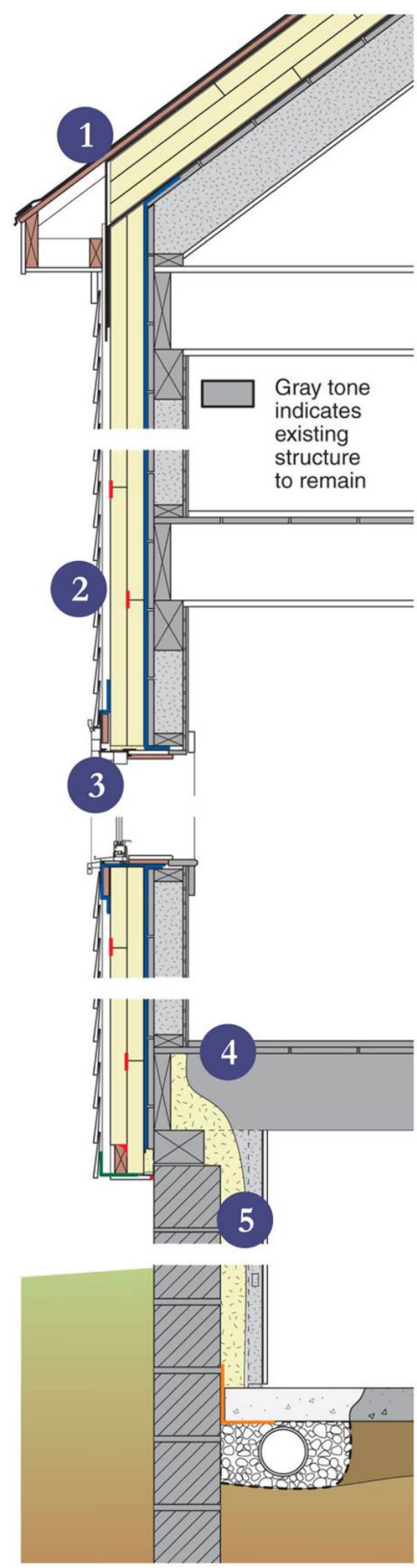
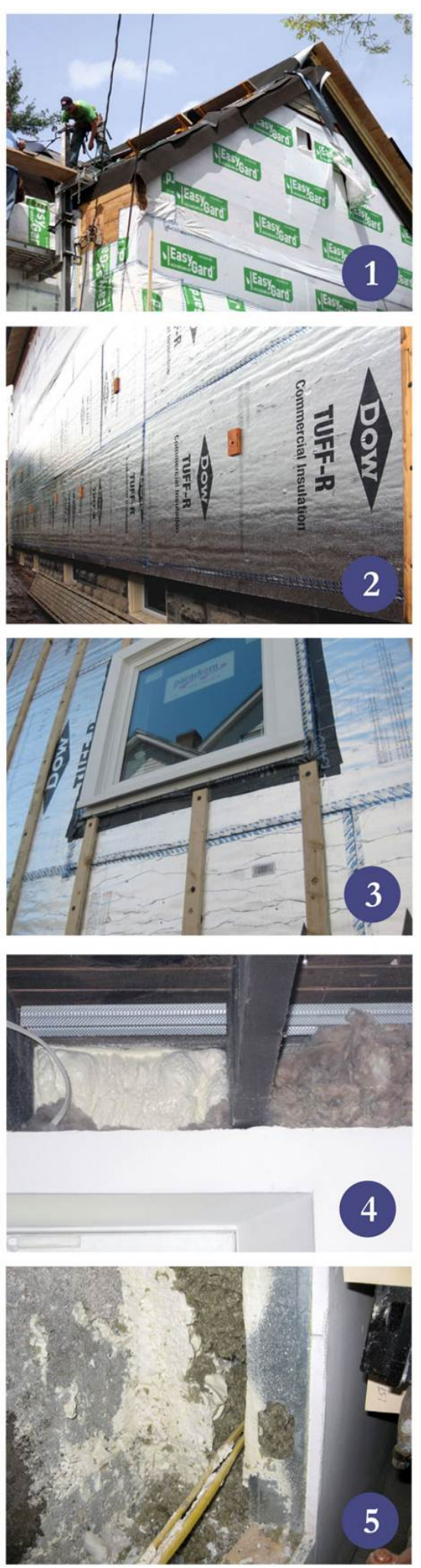

\section{Enclosure Design}

(1)Roof Assembly: Compact (unvented) roof assembly with existing 7" deep rafter bays filled with netted cellulose insulation and with three 2" layers of foil-faced polyisocyanurate exterior insulating sheathing.

(2Wall Assembly: Existing wall framing cavities filled with dry cellulose and two 2" layers of foilfaced polyisocyanurate exterior insulating sheathing.

(3Window Specifications: New Paradigm triple-glazed, krypton/ argon blend, low-E vinyl windows; $\mathrm{U}=0.2, \mathrm{SHGC}=0.25$.

(4) Infiltration: Self-adhering membrane over existing roof sheathing provides air control in field of roof. The taped outer layer of insulating sheathing on the wall is the air control layer for the field of the walls. The roofing membrane overlaps the exterior wall insulation to provide a continuous transition. Closed-cell spray foam provides the air control layer for the foundation wall. The transition from the exterior wall air control to the foundation wall air control is through the mudsill with sealant applied between the exterior insulating sheathing and the mudsill and the spray foam over the foundation wall extending up over the mudsill.

\section{Foundation Assembly:} Conditioned basement with 3 " closed-cell, high-density SPF insulation applied directly to stone foundation walls covered by metal stud walls with rock wool insulation. Sub-slab perimeter drainage system was installed and connected to a new sump pump. A drainage mat was installed along the base of the foundation wall and down under the new section of slab to allow foundation walls to drain to the subslab system. 


\section{Mechanical Design}

(1) Heating and Cooling: For each unit, 96.7 AFUE sealed combustion natural gas furnace in conditioned space with AHRI-rated 14 SEER/12 EER coil installed and connected to outdoor AC unit.

(2Ventilation: For each unit, Energy Recovery Ventilator installed with dedicated ductwork; outside supply ducted to common space; inside exhaust taken from bathrooms.

\section{Space Conditioning}

Distribution: Entire distribution system within thermal enclosure: ductwork in basement for lower unit; ductwork in attic kneewall space and floors for upper unit.

4)DHW: Solar thermal with common 100 gal. tank and, for each unit, a 40 gal. electric backup tank.

5Lighting: ENERGY STAR ${ }^{\circledR} \mathrm{CFL}$ lighting.

Appliances: ENERGY STAR ${ }^{\circledR}$ dishwasher, refrigerator and clothes washer.

6Site Generated Power: 4.3 kW PV system
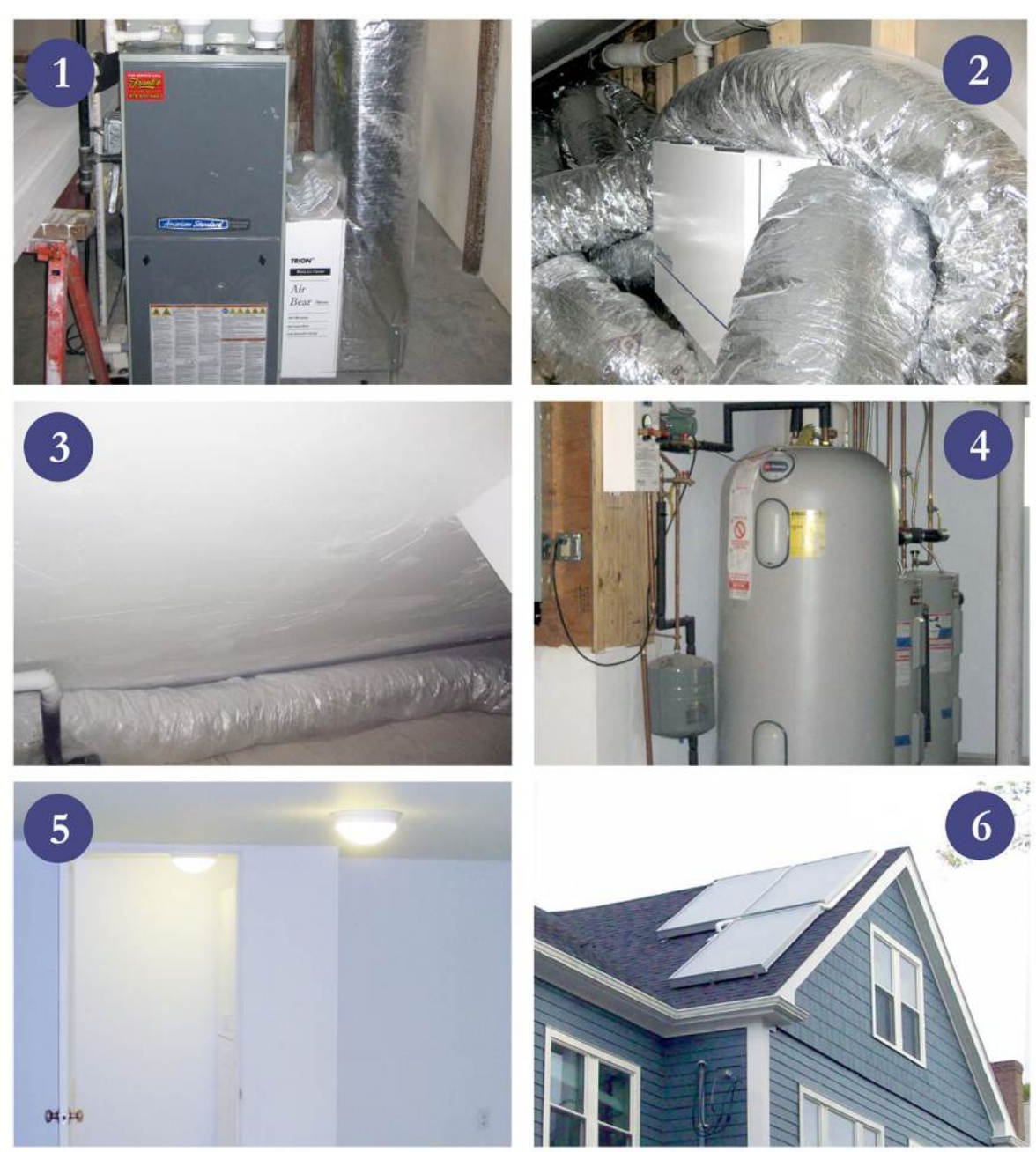


\subsubsection{Quincy Bungalow}

Building Type, Style: $\quad$ Single family detached, Bungalow

Approx Year Built:

1905

Pre-DER Floor Area: $\quad 3,484 \mathrm{ft}^{2}$ including conditioned attic and basement

Post-DER Floor Area: $\quad 4,576 \mathrm{ft}^{2}$ after an additional floor was added

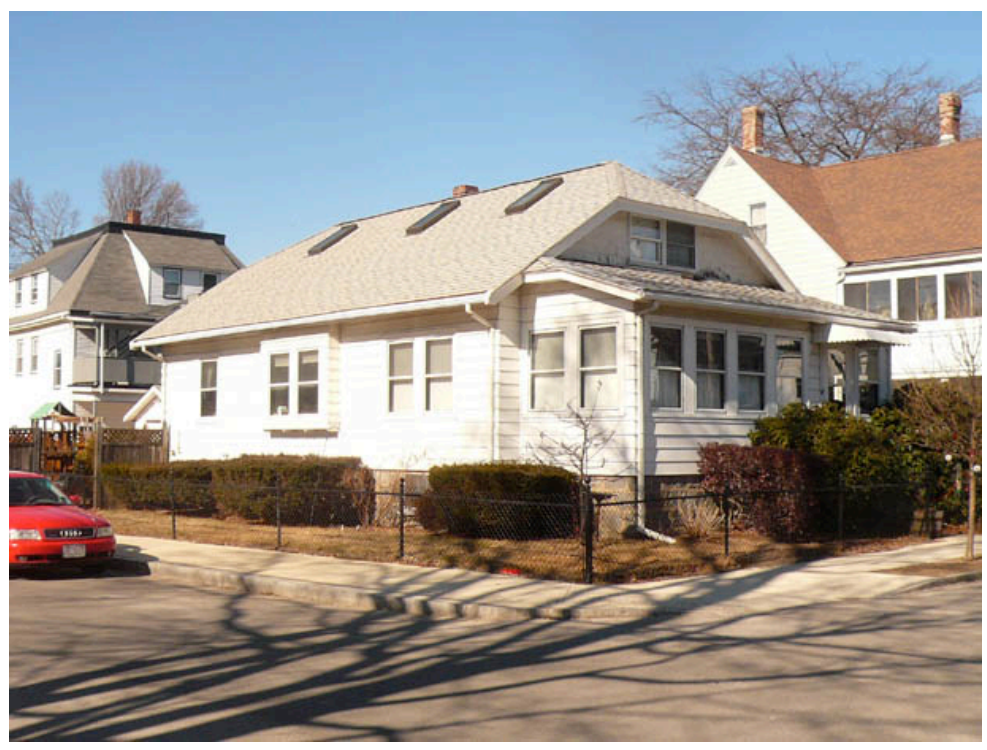

Figure 14. Pre-retrofit Quincy Bungalow

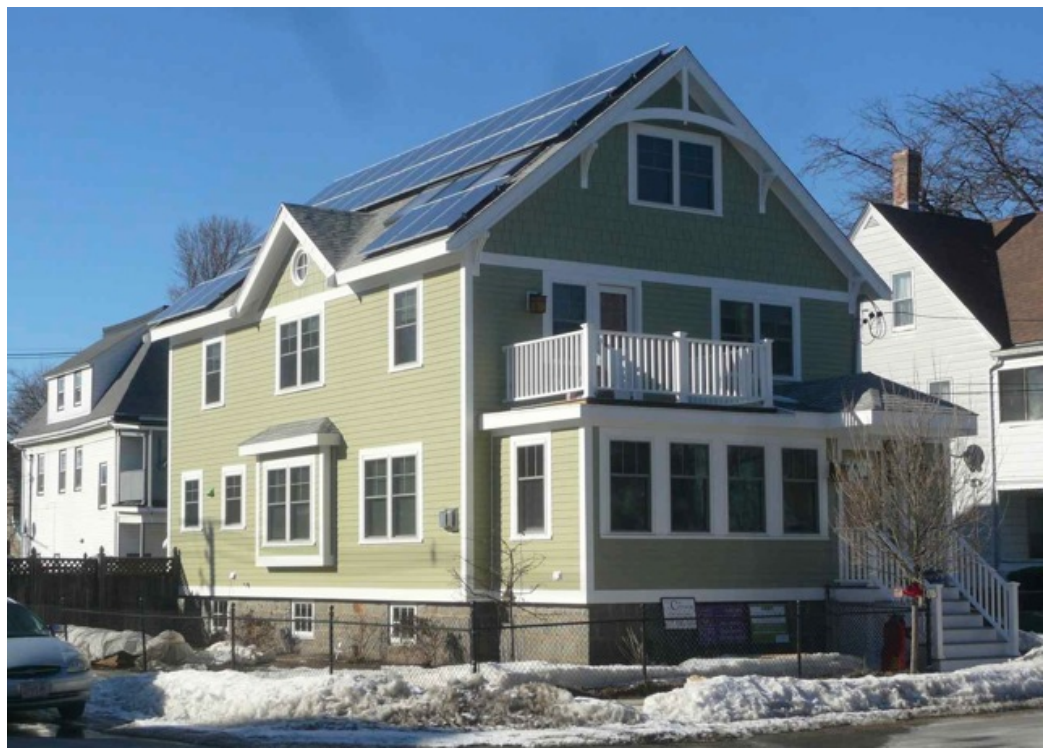

Figure 15. Post-retrofit Quincy Bungalow 
When the owners of this bungalow-style home in Quincy, Massachusetts originally decided on a major expansion, significant energy improvements were not part of their plan. The decision to perform a National Grid DER was made after the architect on the project, Henry MacLean of Timeless Architecture, learned of the program. The owners decided to pursue the DER to help fund the project and benefit from future energy savings while expanding available space for their five-person family.

The expansion is shown by comparison of Figure 14 and Figure 15. During the DER process an additional floor was added to the home, as well as an entirely new roof with a $6.25-\mathrm{kW}$ photovoltaic (PV) array and solar thermal system. The homeowners lived elsewhere for approximately six months during the retrofit process.

The owners are pursuing THC designation through Affordable Comfort, Inc. They hope to earn the additional \$10,000 incentive offered by National Grid for achieving the THC energy targets.

The following pages describe the enclosure and mechanical system improvements implemented as part of the retrofit. 

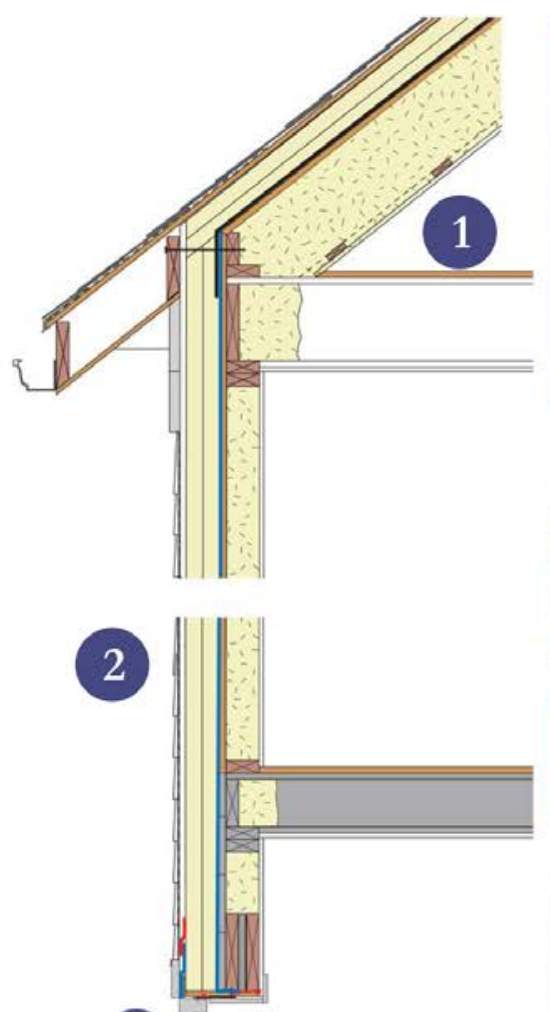

3

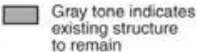
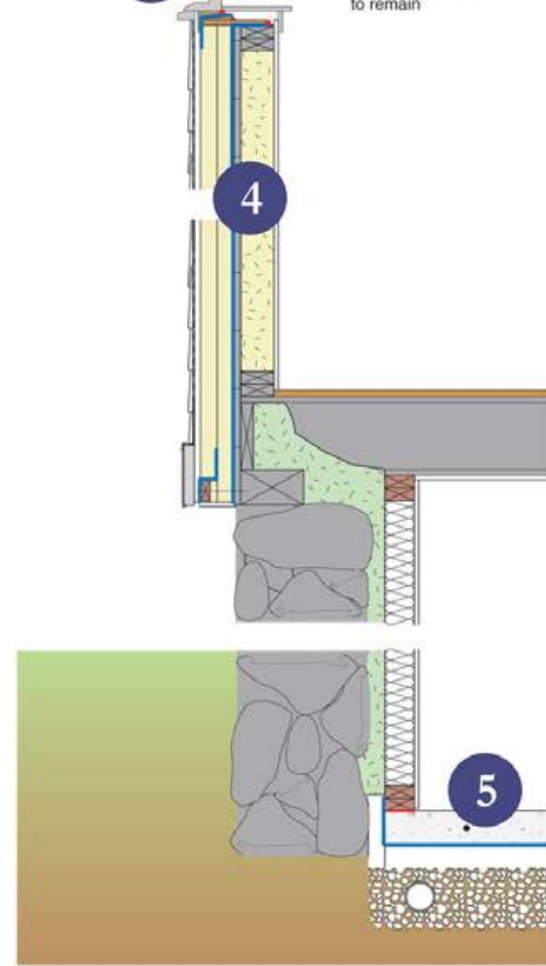
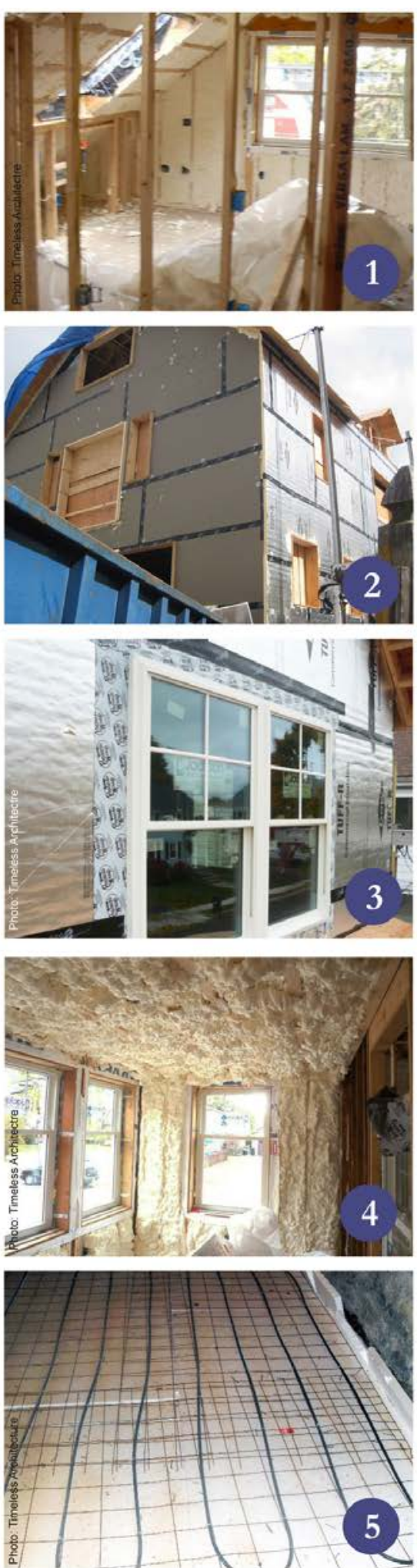

\section{Enclosure Design}

(1) Roof Assembly: R-62 unvented roof: $10 "$ Icynene ${ }^{\oplus}$ open-cell spray foam insulation in rafter cavities; roof sheathing; housewrap; two layers of 2" polyisocyanurate insulating sheathing, joints offset and taped; plywood nail base; roof underlayment; asphalt shingles.

(2) Wall Assembly: R-38 (nominal): Icynene ${ }^{\oplus}$ open-cell spray foam insulation in $2 \times 4$ wall framing cavities; existing board sheathing or new plywood sheathing; housewrap; two layers of 2" polyisocyanurate insulating sheathing joints offset and taped; $1 \times 3$ wood furring; fiber cement siding.

(3) Window Specifications: New Paradigm triple-pane, vinyl framed, low-e, krypton blend or argon gas filled; $\mathrm{U}=0.20-0.26$, $\mathrm{SHGC}=0.23$ 0.21 ; windows installed in plane with primary water control layer.

(4) Infiltration: Taped housewrap over roof and wall sheathing; adhered membrane wrapping from roof to wall; two layers of 2 " polyisocyanurate insulating sheathing joints offset and taped; open-cell spray foam insulation in wall and roof framing cavities; closed-cell spray foam applied over framing sill and granite block foundation wall; spray foam extends to new concrete slab.

\section{(5Foundation Assembly:} Conditioned basement: 2" closedcell spray foam applied over framing sill and foundation wall; $3 \frac{1}{2} "$ fiberglass batt in new wall framing cavity; $6-10^{\prime \prime}$ gravel, 21/2" EPS insulation; polyethylene vapor retarder under new concrete slab with radiant tubing. 


\section{Mechanical Design}

(1) 2) Heating and Cooling: Carrier Infinity two stage heat pump; SEER 16.5; HSPF 9.5; Phoenix Evolution Versa-Hydro ${ }^{T M}$ direct-fired storage water heater with heat exchanger for heating and for input from solar thermal system.

(3) Ventilation: LifeBreath HRV, ducted to central AHU distribution.

\section{(4) Space Conditioning}

Distribution: Ductwork for

forced-air system entirely within conditioned space; hydronic radiant in new concrete basement slab; hydronic panel radiator at entry and front/porch room.

5DHW: Phoenix Evolution VersaHydro $^{\mathrm{TM}}$ direct-fired storage water heater with heat exchanger for input from 6 Velux integrated solar thermal collector panels.

Lighting: ENERGY STAR ${ }^{\circledast}$ CFL lighting.

Appliances: ENERGY STAR ${ }^{\circledR}$ dishwasher, refrigerator and clothes washer.

6 Site Generated Power: $6.25 \mathrm{~kW}$ solar PV array.
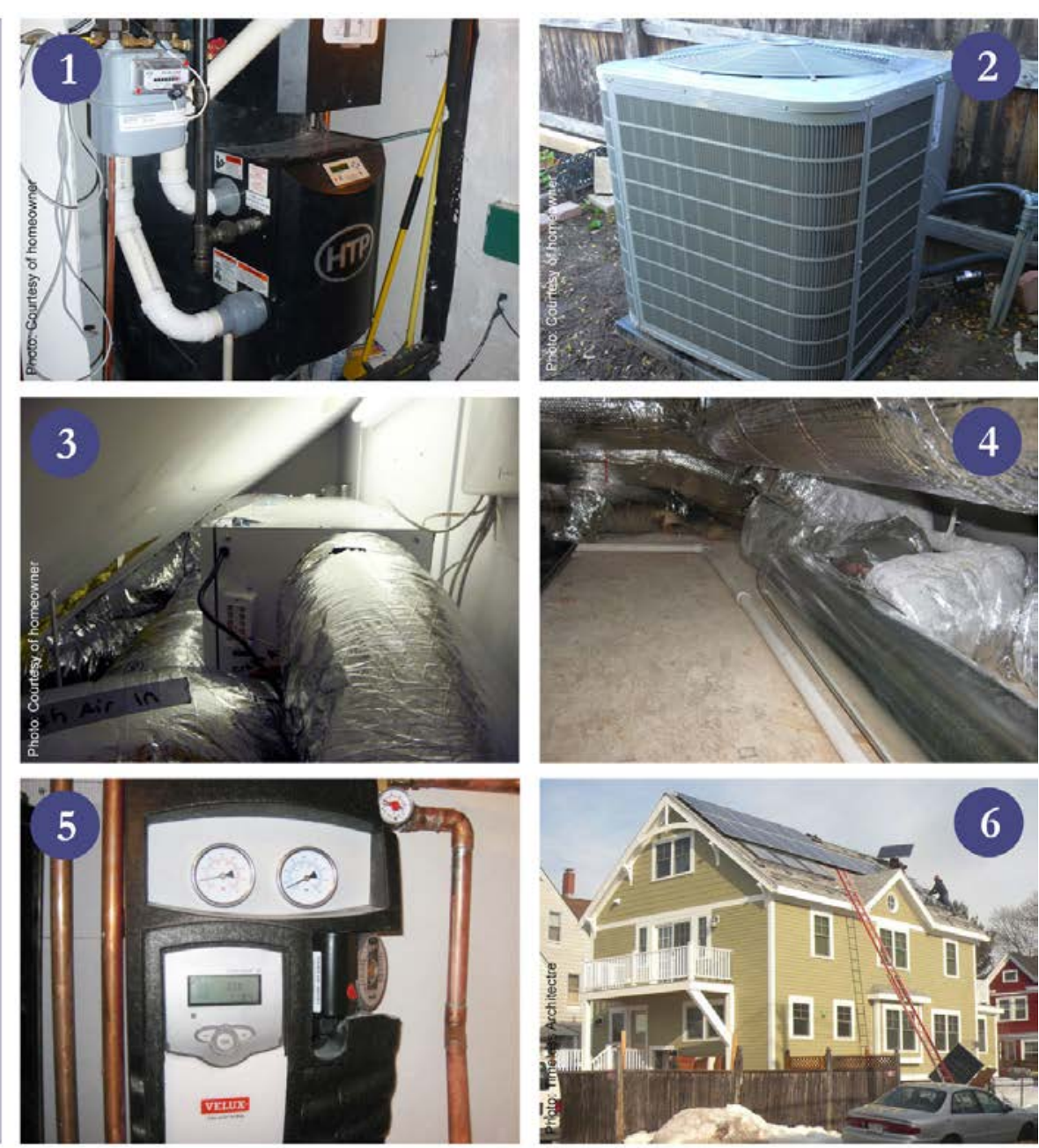


\subsubsection{Millbury Cape}

$\begin{array}{ll}\text { Building Type, Style: } & \text { Cape } \\ \text { Approx Year Built: } & 1953 \\ \text { Floor Area: } & 1,868 \mathrm{ft}^{2} \text { including the basement }\end{array}$

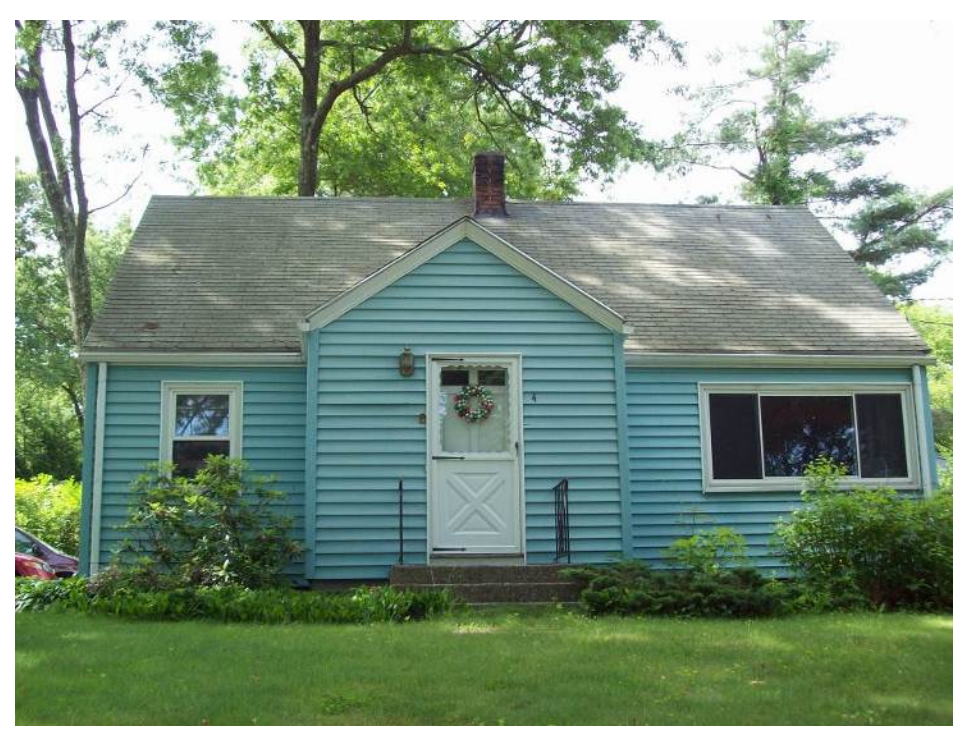

Figure 16. Pre-retrofit Millbury Cape

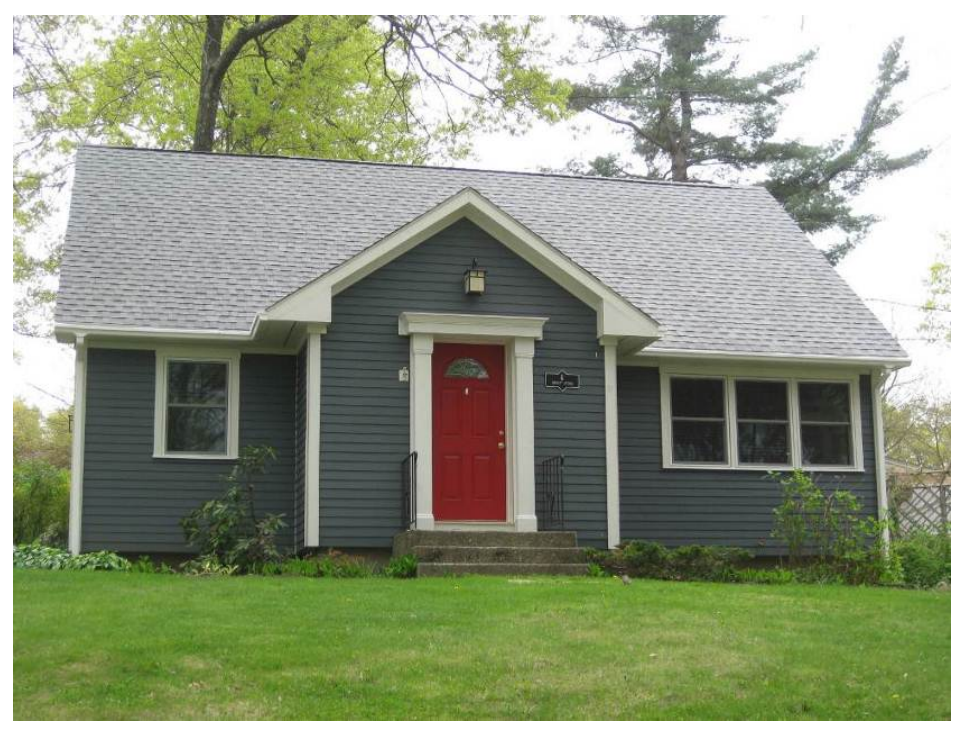

Figure 17. Post-retrofit Millbury Cape

The project team for this National Grid DER consisted of Synergy Construction as the contractor and Wilson Bros. Heating \& Air Conditioning as the HVAC contractor, with BSC acting as a consultant. 
This Cape Cod style house was built in 1953. Although the owners had made interior improvements and necessary repairs in the 25 years since they purchased the house, they now wanted to do some exterior upgrades and at the same time tighten up the house in keeping with their long-standing goal of becoming energy efficient and reducing their impact on the environment.

This project was among the first to be accepted into the National Grid DER pilot program. In order to reach the goals of a DER, the overall retrofit strategy was to apply exterior insulating sheathing to the walls and roof, replace the existing windows with high performance windows, and insulate the basement. Because nearly all of the work was exterior, the owners were able to stay in their home throughout the retrofit project.

The overall retrofit strategy for the enclosure was to first wrap the above-grade portion of the house, including the roof, with a continuous air barrier and then to wrap it again in continuous layers of insulation. Because the wall framing cavities already contained batt insulation and insulation could easily be added to the rafter bays in the unfinished attic, the combination of exterior insulation and cavity insulation satisfied the R-40 and R-60 DER targets for the walls and roof, respectively. Once the additional roof assembly was in place, eave and rake overhangs were built and attached to the building structure through the insulating sheathing. This simple action of adding overhangs is a major improvement in water management, which the original house was lacking, and is a significant durability upgrade.

To complete the enclosure improvements, the windows were replaced with new triple-glazed windows and the basement was insulated by applying insulation to the interior of the concrete foundation walls and over the existing basement slab.

The project replaced the existing $30+$ year old oil boiler and four window air conditioners with a mini-split heat pump system to provide heating and cooling using two small ducted air handlers - one in the basement and the other in attic space - and a single outdoor condensing unit. During the winter, the owners had often preferred using their pellet stove for heating. By providing an airtight door and adding combustion air and exhaust ducts that connected directly to the outside, they were able to keep this to use as a backup heating system.

As the first in this neighborhood to undergo a DER, this project serves as a demonstration for other homeowners that this type of house can be made energy efficient without making other major changes and while continuing to live in the home.

During the course of the project the owners decided to enlarge an existing shed dormer on the second floor to increase their living space. The opportunity to perform energy efficiency and durability upgrades along with other home improvements highlights another justification for a retrofit project.

The following pages show details of the enclosure and mechanical system upgrades performed as part of the retrofit. 


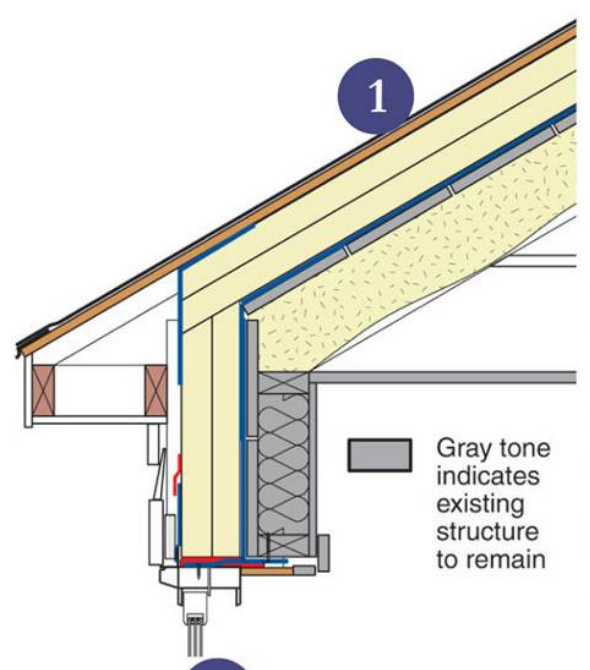

4
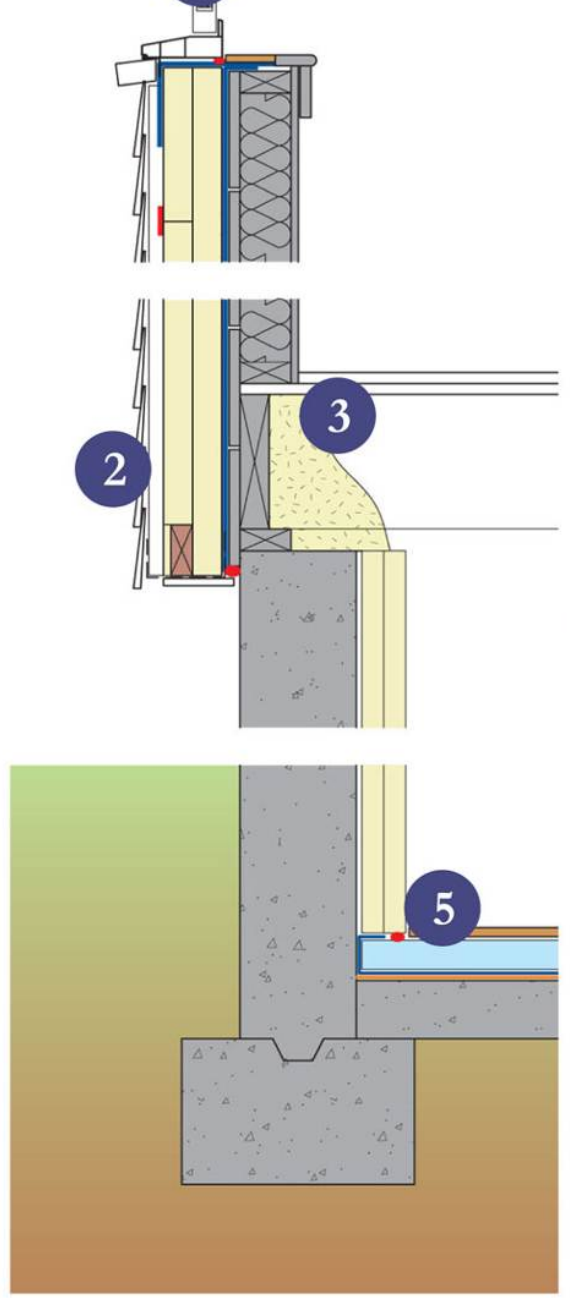
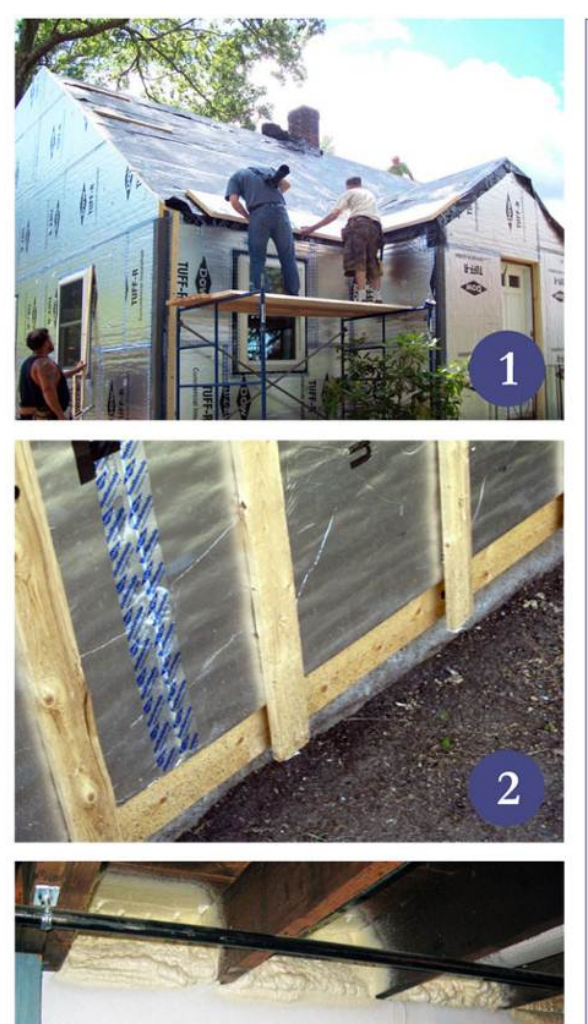

Enclosure Design

(1) Roof Assembly: Compact (unvented) roof assembly with existing rafter bays filled with spray foam and with two 2" layers of foil-faced polyisocyanurate exterior insulating sheathing.

(2) Wall Assembly: Existing wall framing cavities already contained batt insulation; two 2" layers of foil-faced polyisocyanurate exterior insulating sheathing were applied to the outside.

(3) Infiltration: Self-adhering membrane over existing roof sheathing provides air control in field of roof; house wrap applied shingle style, with seams and edges taped, over the existing wall sheathing provides air control in the field of the wall; roofing membrane overlaps onto the house wrap to establish continuity of the air barrier system; air barrier system transitions through the mudsill to the spray foam insulation on the inside; this connects with the taped insulation board that is applied to the inside of the basement wall.
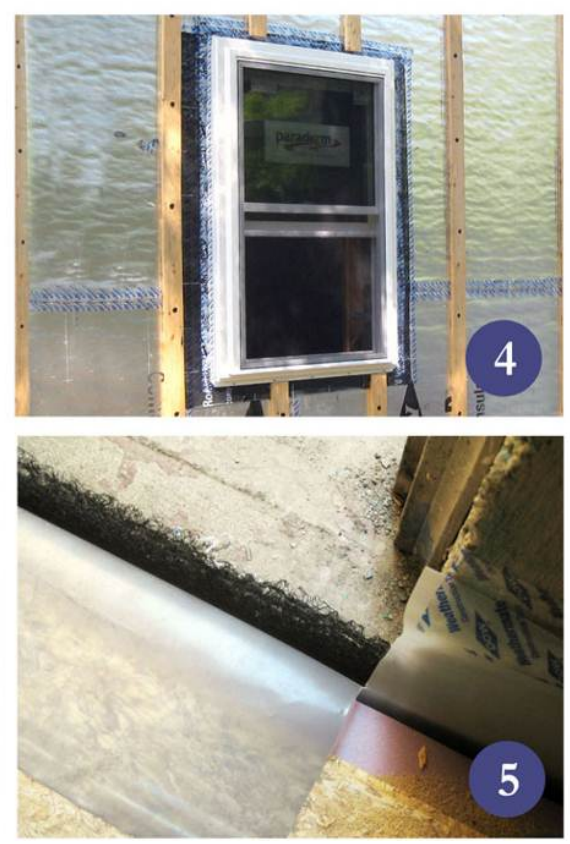

(4) Window Specifications: New Paradigm triple glazed, argon-filled, low $E$ double hung vinyl windows; $\mathrm{U}=0.25, \mathrm{SHGC}=0.25$.

\section{Foundation Assembly:}

Conditioned basement with 3 " rigid polyisocyanurate insulation applied to the concrete foundation walls; to provide insulation for the concrete slab as well as provide some water management capacity, a drainage mat was placed over the existing slab, followed by polyethylene vapor barrier and then rigid insulation; a floating subfloor completes the new floor assembly. 
Mechanical Design

(1) Heating and Cooling: Minisplit heating and cooling heat pump system with two ducted air handlers and one outdoor unit; one air handler is located in the basement and one is in kneewall space; direct vented pellet stove is available as backup for heat.

(2) Ventilation: An outdoor air supply is integrated with each air handler; outdoor air intake ducts are provided with ventilation controllers and mechanical dampers; spot exhaust fans are provided in the bathrooms.

\section{3) Space Conditioning}

Distribution: Insulated sheet metal trunks with insulated flex run-outs; entire distribution system within thermal enclosure; ductwork in basement ceiling for basement air handler; ductwork in attic and kneewall space for the second floor air handler.
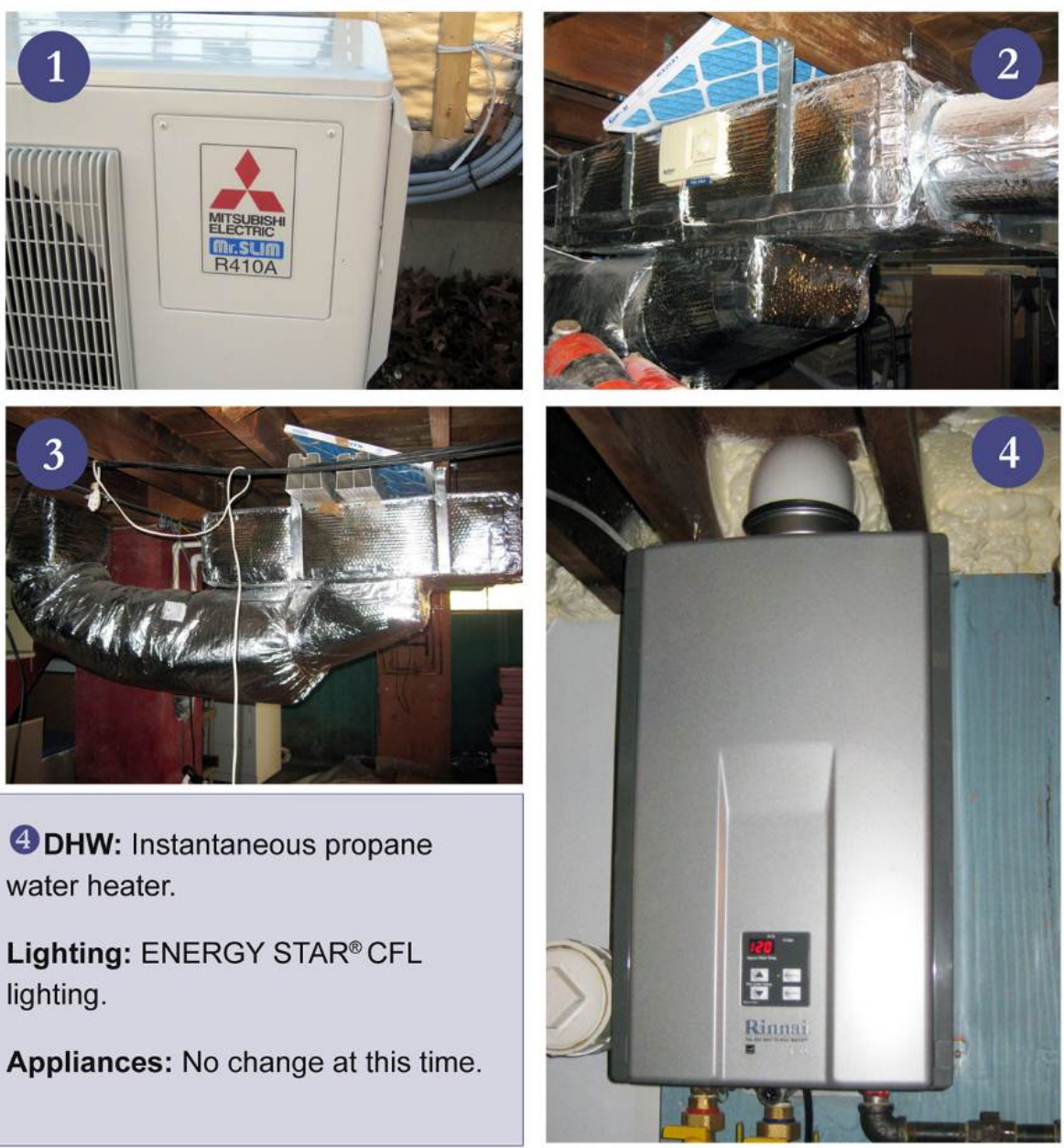


\section{Analysis}

Detailed pre- and post-retrofit data collection is a key component to the success of retrofits in the United States. However, it is often difficult to collect these data for a variety of reasons. The focus of a project is usually on completion of the physical steps instead of on careful documentation that would be useful for future endeavors.

\subsection{Areas, Volumes, and Airtightness}

Data about the floor areas, conditioned volumes, and enclosure areas were carefully collected in order to best understand post-retrofit performance and improvement over the pre-retrofit state. Blower door testing was performed by BSC for many of these projects, and provided by team members for others. These results are tabulated in Table 2.

Regarding the areas and volumes tabulated, the basement and attic were excluded if not conditioned in the pre-retrofit state. Once these areas were brought within the thermal enclosure as part of the retrofit, their areas and volumes were included in the post-retrofit tabulations.

The blower door results were expressed in three formats; CFM 50 is the airflow measured during the test. This number can then be converted to ACH $50 \mathrm{~Pa}$, a commonly used metric, which is sometimes confusing when it is not clear whether or not the basement is included in the volume. BSC has observed that typical air leakage in existing cold climate homes is in the range of 6-8 $\mathrm{ACH} 50$, but numbers as high as $12-15$ are not uncommon. The last blower door metric, CFM $50 / \mathrm{ft}^{2}$ of building enclosure, is useful because it directly relates the measured CFM from the blower door testing to the square footage of enclosure (roof, above grade walls, basement walls, and slab) through which the air leakage occurs. This enables a clearer comparison between projects that may have a variety of sizes and enclosure areas.

The pre-retrofit testing of the Belchertown Cape should be noted, especially the $57.7 \mathrm{ACH} 50 \mathrm{~Pa}$ result. In this case, very large air leakage pathways existed in the attic area. The testing was performed with an attempt to close the basement door, which could not fully shut; a 4-in. wide gap was left open. The basement was partially open to the outdoors on one side; daylight was clearly visible through one of the basement walls. The retrofit effort resulted in significant reduction of this leakage and much greater thermal comfort.

As shown, only two of the homes achieved the stringent National Grid DER goal of testing below $0.1 \mathrm{CFM} 50 / \mathrm{ft}^{2}$ of building enclosure, though two other homes came extremely close considering typical margins of error for the testing due to various testing condition factors such as wind. However, all of the homes showed a significant reduction in air leakage following the retrofit, with the exception of the Bedford Farmhouse, for which pre-retrofit data were not available. 
Table 2. Floor and Enclosure Areas, Volumes, and Blower Door Results

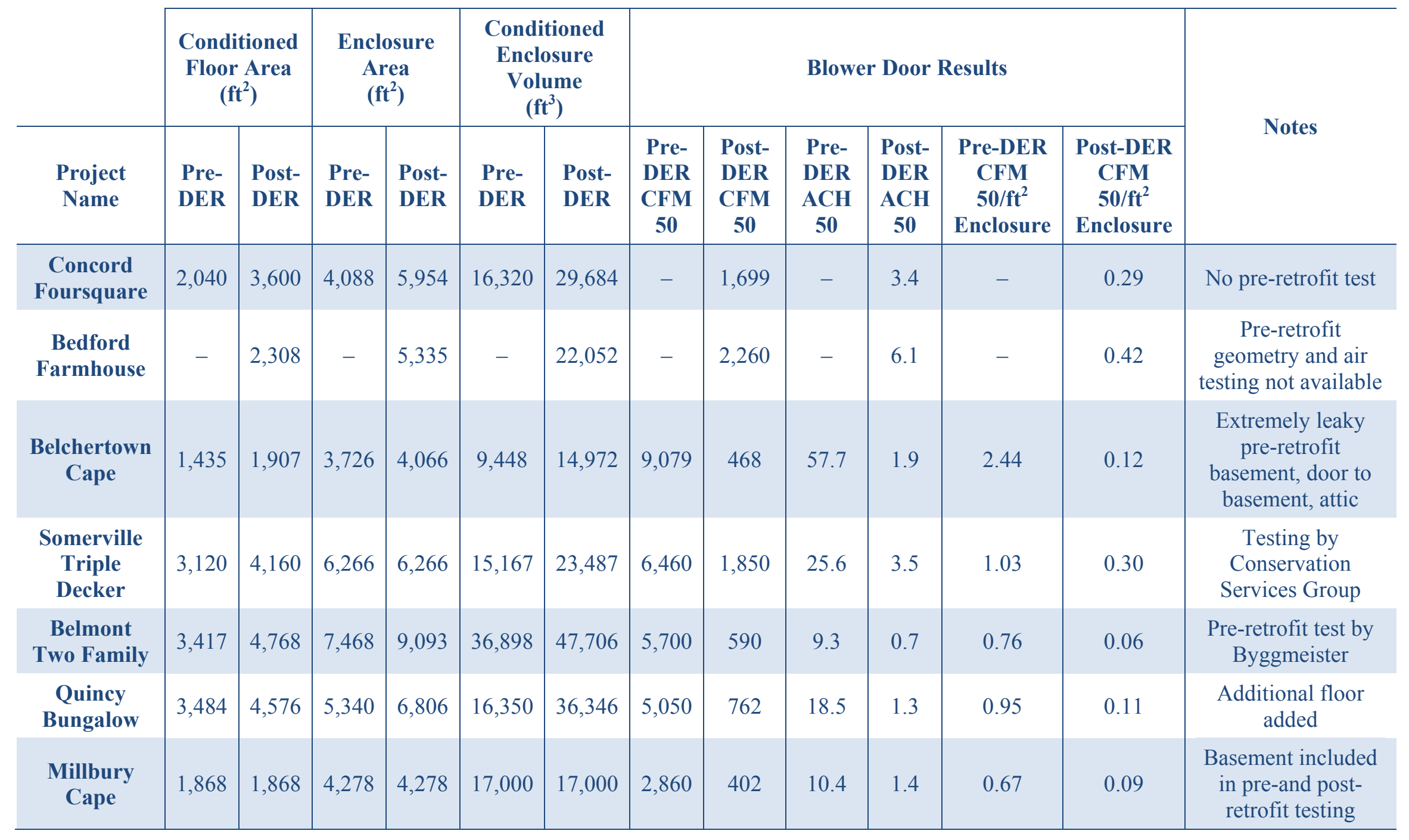




\subsection{Project Costs}

The cost of a retrofit is always of interest to homeowners considering a significant remodel or DER. Often the homeowner plans to incorporate nonenergy-motivated renovations such as expansions or interior improvements. An attempt was made to separate the costs of efforts such as redoing kitchens and bathrooms from the energy-related upgrades.

For homes that are part of the National Grid DER program, costs are estimated in the planning stage as part of the application. These cost estimates must be divided into those that will be incentivized and those that will not. Costs that are incentivized by the program ("allowable costs") include insulation, air sealing, and mechanical systems. Examples of costs that are not incentivized ("non-allowable costs") include shingles, cladding, electrical work, and any necessary repairs to the structure. These costs are considered part of regular maintenance to the home and not specific to DER efforts. Many homeowners choose to do additional interior work such as remodeling kitchens and bathrooms; these costs are also excluded from National Grid incentives.

Table 3 shows the estimated costs for each project. For National Grid projects, these are the costs included in the applications; in all cases, it is possible that final costs differed once additional issues were discovered or plans changed. However, National Grid does not require a reassessment of real costs after the retrofit is complete and it is usually difficult to obtain this information. Allowable costs per square foot of post-retrofit finished floor area are also included.

The National Grid terminology of allowable versus non-allowable costs was used in the table even though it includes non-National Grid projects (the Concord Foursquare and Somerville Triple Decker). For the Concord Foursquare, the equivalent allowable versus non-allowable costs were estimated by the owner. Although this home had the highest total cost, the project included significant interior remodeling; the estimated "allowable cost" is within the range of the other projects.

The Bedford Farmhouse was excluded from the table because Habitat for Humanity projects are built with largely volunteer labor, making use of many donated materials. Although not every future home retrofit will participate in an incentive program such as National Grid, it is useful to understand ballpark costs broken into those that go beyond standard construction to significantly improve energy efficiency, comfort, and durability, and those that are part of standard home maintenance or interior improvements. 
Table 3. Project Costs

\begin{tabular}{c|c|c|c|c}
\hline Project Name & $\begin{array}{c}\text { Total } \\
\text { Retrofit Cost }\end{array}$ & $\begin{array}{c}\text { Non- } \\
\text { Allowable } \\
\text { Cost }\end{array}$ & Allowable Cost & $\begin{array}{c}\text { Allowable Cost/ft } \mathbf{f o f}^{2} \\
\text { Post-Retrofit } \\
\text { Finished Floor Area }\end{array}$ \\
\hline $\begin{array}{c}\text { Concord } \\
\text { Foursquare }\end{array}$ & $\$ 300,000$ & $\$ 225,000$ & $\$ 75,000$ & $\$ 20.83$ \\
$\begin{array}{c}\text { Belchertown } \\
\text { Cape }\end{array}$ & $\$ 64,629$ & $\$ 9,700$ & $\$ 54,929$ & $\$ 28.80$ \\
$\begin{array}{c}\text { Somerville } \\
\text { Triple Decker }\end{array}$ & $\$ 205,000$ & - & - & - \\
\hline $\begin{array}{c}\text { Belmont Two } \\
\text { Family }\end{array}$ & $\$ 192,008$ & $\$ 36,785$ & $\$ 155,223$ & $\$ 32.56$ \\
$\begin{array}{c}\text { Quincy } \\
\text { Bungalow }\end{array}$ & $\$ 125,547$ & $\$ 27,064$ & $\$ 98,483$ & $\$ 21.52$ \\
\hline Millbury Cape & $\$ 82,719$ & $\$ 16,485$ & $\$ 66,234$ & $\$ 35.46$ \\
\hline
\end{tabular}

\subsection{Modeling and Energy Analysis}

Energy performance measurement is a key metric of retrofit project success. No post-retrofit energy use requirements are part of the National Grid program, but participant homes are required to make their pre- and post-retrofit utility data available for research purposes. The nonNational Grid project owners were also quite willing to provide the utility data they had. An effort was made to collect as many available utility data as possible. The owners of several of the projects (the Concord Foursquare, the Bedford Farmhouse, and the Belmont Two Family) did not own the homes prior to the retrofits. In these cases, energy models were used to estimate preretrofit energy use, with the exception of the Bedford Farmhouse, for which insufficient preretrofit information was available. When possible, an attempt was made to match pre-retrofit schedules and occupancy to the post-retrofit conditions.

Pre- and post-retrofit energy use breakdown and savings from the pre-retrofit case are tabulated in Table 4 and Table 5. Source to site energy conversions were taken from standard factors used by ENERGY STAR ${ }^{\circledR}$ (Figure 18). 


\begin{tabular}{|c|c||}
\hline \multicolumn{2}{|c||}{ Source-Site Ratios for all Portfolio Manager Fuels } \\
\hline Fuel Type & Source-Site Ratio \\
\hline Electricity (Grid Purchase) & 3.34 \\
\hline Electricity (on-Site Solar or Wind Installation) & 1.0 \\
\hline Natural Gas & 1.047 \\
\hline Fuel Oil (1,2,4,5,6,Diesel, Kerosene) & 1.01 \\
\hline Propane \& Liquid Propane & 1.01 \\
\hline Steam & 1.21 \\
\hline Hot Water & 1.28 \\
\hline Chilled Water & 1.05 \\
\hline Wood & 1.0 \\
\hline Coal/Coke & 1.0 \\
\hline Other & 1.0 \\
\hline
\end{tabular}

Figure 18. Source-site energy ratios taken from EnergyStar.gov

(ENERGY STAR 2011)

It is important to note that the numbers in Table 5 are calculated from (at best) single years of data available before and after the retrofit. In the rare cases where more than a year of data was available for the pre- or post-retrofit state, a "typical" year was selected. As described, several of the homes have no pre-retrofit data, and model predictions had to be compared to actual use.

Several homes had a only bout six months of post-retrofit data, and it was necessary to interpolate the remaining months to estimate yearly energy use. These numbers do not necessarily represent the long-term energy performance of any of these homes and are affected by a variety of factors, including weather, homeowner operation, and fuel choices, and varying numbers of occupants. It is important to continue monitoring these homes over several years to gain a more complete understanding of their long-term energy performance as occupants settle into the homes.

The source energy use of each home before and after the retrofits is graphed in Figure 19. Note that neither utility data nor sufficient information to create a model was available for the preretrofit state of the Bedford Farmhouse. The additional source energy reduction from the use of PV systems is included for the three homes with solar arrays. The homes achieve source energy savings of $23 \%-74 \%$. The homes with PV arrays achieve an additional $11 \%-18 \%$ source energy savings when the amount of electricity generated over a year is subtracted from the amount used by homes. 
Table 4. Summary of Pre-DER Energy Use

\begin{tabular}{|c|c|c|c|c|c|c|c|c|c|c|}
\hline $\begin{array}{c}\text { Project } \\
\text { Name }\end{array}$ & $\begin{array}{l}\text { Time } \\
\text { Period }\end{array}$ & $\begin{array}{c}\text { Electricity } \\
(\mathrm{kWh})\end{array}$ & $\begin{array}{c}\text { Gas } \\
\text { (therms) }\end{array}$ & $\begin{array}{l}\text { Propane } \\
\text { (gal) }\end{array}$ & $\begin{array}{l}\text { Fuel Oil } \\
\text { (gal) }\end{array}$ & $\begin{array}{l}\text { Wood } \\
\text { (cords) }\end{array}$ & $\begin{array}{c}\text { Pellets } \\
\text { (bags) }\end{array}$ & $\begin{array}{c}\text { Total } \\
\text { Source } \\
\text { Energy } \\
\text { (MMBtu) }\end{array}$ & $\begin{array}{l}\text { Total } \\
\text { Energy } \\
\text { Cost }\end{array}$ & Comments \\
\hline $\begin{array}{l}\text { Concord } \\
\text { Foursquare }\end{array}$ & $\begin{array}{c}\text { Energy } \\
\text { Model } \\
\text { (TMY File) }\end{array}$ & 10,671 & 2,340 & - & - & - & - & 367 & $\$ 4,527$ & $\begin{array}{c}\text { Values estimated } \\
\text { by energy modeling } \\
\text { using state average } \\
\text { utility costs }\end{array}$ \\
\hline $\begin{array}{c}\text { Bedford } \\
\text { Farmhouse }\end{array}$ & - & - & - & - & - & - & - & - & - & $\begin{array}{l}\text { Information } \\
\text { insufficient to } \\
\text { create model }\end{array}$ \\
\hline $\begin{array}{l}\text { Belchertown } \\
\text { Cape }\end{array}$ & $\begin{array}{c}01 / 2009 \\
12 / 2009\end{array}$ & 3,164 & - & 103.5 & - & 7 & - & 217 & $\$ 2,417$ & $\begin{array}{l}\text { Incomplete monthly } \\
\text { costs available; } \\
\text { missing values } \\
\text { estimated* }\end{array}$ \\
\hline $\begin{array}{l}\text { Somerville } \\
\text { Triple } \\
\text { Decker }\end{array}$ & $\begin{array}{c}09 / 2009 \\
08 / 2010\end{array}$ & 8,135 & 987 & - & - & - & - & 196 & $\$ 3,075$ & $\begin{array}{l}\text { Incomplete monthly } \\
\text { costs available; } \\
\text { missing values } \\
\text { estimated }\end{array}$ \\
\hline $\begin{array}{l}\text { Belmont } \\
\text { Two Family }\end{array}$ & $\begin{array}{c}\text { Energy } \\
\text { Model } \\
\text { (TMY File) }\end{array}$ & 9,261 & - & - & 3,078 & - & - & 572 & - & $\begin{array}{c}\text { Values estimated } \\
\text { by energy modeling } \\
\text { using state average } \\
\text { utility costs }\end{array}$ \\
\hline $\begin{array}{c}\text { Quincy } \\
\text { Bungalow }\end{array}$ & $\begin{array}{c}05 / 2009- \\
04 / 2010\end{array}$ & 12,556 & - & - & 1,134 & - & - & 315 & $\$ 5,818$ & $\begin{array}{c}\text { Fuel oil use } \\
\text { unavailable; } \\
\text { estimated by energy } \\
\text { model }\end{array}$ \\
\hline $\begin{array}{c}\text { Millbury } \\
\text { Cape }\end{array}$ & $\begin{array}{c}09 / 2009 \\
08 / 2010\end{array}$ & 7,570 & - & - & 375 & - & 150 & 190 & $\$ 3,252$ & $\begin{array}{c}\text { Values estimated } \\
\text { by energy modeling } \\
\text { using state average } \\
\text { utility costs }\end{array}$ \\
\hline
\end{tabular}

* Estimated wood costs included even though wood was obtained for free as part of homeowner's job. 
Table 5. Summary of Post-DER Energy Use

\begin{tabular}{|c|c|c|c|c|c|c|c|c|c|c|c|c|c|}
\hline $\begin{array}{l}\text { Project } \\
\text { Name }\end{array}$ & 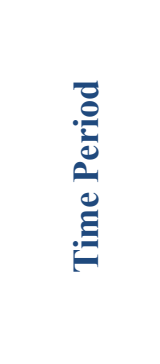 & 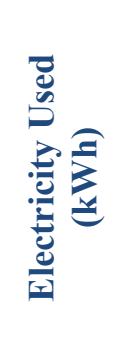 & 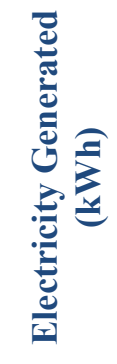 & ڤ્气 & & 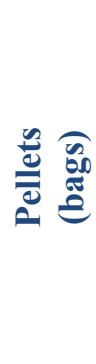 & 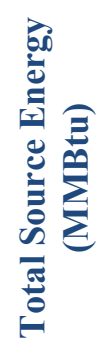 & 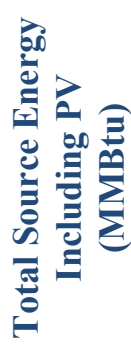 & 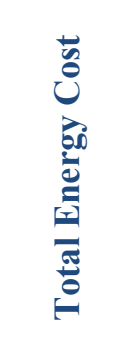 & 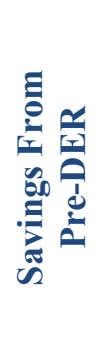 & 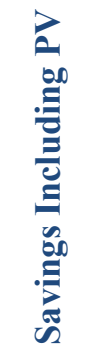 & 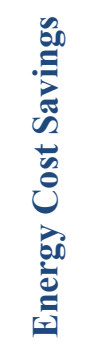 & Comments \\
\hline $\begin{array}{l}\text { Concord } \\
\text { Foursquare }\end{array}$ & $\begin{array}{c}02 / 2010 \\
01 / 2011\end{array}$ & 3,773 & 5,698 & 740 & - & - & 120 & 56 & $\$ 1,307$ & $67 \%$ & $85 \%$ & $71 \%$ & $\begin{array}{l}\text { Incomplete monthly costs available; } \\
\text { missing values estimated }\end{array}$ \\
\hline $\begin{array}{l}\text { Bedford } \\
\text { Farmhouse }\end{array}$ & $\begin{array}{c}02 / 2010 \\
01 / 2011\end{array}$ & 6,109 & - & 416 & - & - & 113 & - & $\$ 1,721$ & - & - & - & Pre-retrofit information unavailable \\
\hline $\begin{array}{l}\text { Belchertown } \\
\text { Cape }\end{array}$ & $\begin{array}{c}02 / 2010 \\
01 / 2011\end{array}$ & 2,280 & - & - & 357 & - & 59 & - & $\$ 1,422$ & $73 \%$ & - & $41 \%$ & $\begin{array}{l}\text { Incomplete monthly costs available; } \\
\text { missing values estimated }\end{array}$ \\
\hline $\begin{array}{l}\text { Somerville } \\
\text { Triple } \\
\text { Decker }\end{array}$ & $\begin{array}{c}06 / 2010 \\
05 / 2011\end{array}$ & 6,017 & - & 547 & - & - & 126 & - & $\$ 2,139$ & $36 \%$ & - & $30 \%$ & $\begin{array}{l}\text { Incomplete monthly costs available; } \\
\text { missing values estimated }\end{array}$ \\
\hline $\begin{array}{l}\text { Belmont Two } \\
\text { Family }\end{array}$ & $\begin{array}{c}07 / 2010 \\
06 / 2011\end{array}$ & 10,290 & 5,694 & 318 & - & - & 151 & 86 & - & $74 \%$ & $85 \%$ & - & $\begin{array}{c}\text { Several months of energy use } \\
\text { unavailable; missing values estimated. } \\
\text { Costs and savings from electricity use and } \\
\text { PV generation could not be calculated } \\
\text { because instantaneous sales and use data } \\
\text { are lacking. }\end{array}$ \\
\hline $\begin{array}{l}\text { Quincy } \\
\text { Bungalow }\end{array}$ & $\begin{array}{c}08 / 2011- \\
07 / 2011\end{array}$ & 10,629 & 7,008 & 620 & - & - & 186 & 106 & - & $41 \%$ & $66 \%$ & - & $\begin{array}{c}\text { Several months of energy use } \\
\text { unavailable; missing values estimated. } \\
\text { Costs and savings from electricity use and } \\
\text { PV generation could not be calculated } \\
\text { because instantaneous sales and use data } \\
\text { are lacking. }\end{array}$ \\
\hline $\begin{array}{l}\text { Millbury } \\
\text { Cape }\end{array}$ & $\begin{array}{c}09 / 2010 \\
08 / 2011\end{array}$ & 11,058 & - & - & 52 & 50 & 146 & - & $\$ 2,166$ & $23 \%$ & - & $33 \%$ & $\begin{array}{l}\text { Several months of energy use } \\
\text { unavailable; missing values estimated. } \\
\text { Only one month estimated. }\end{array}$ \\
\hline
\end{tabular}


Figure 20 shows the pre- and post-retrofit energy use normalized by square foot, or energy use index. Additionally, these numbers were compared to Northeastern regional averages and 2030 Challenge goals. The 2030 Challenge, advocated by the nonprofit organization Architecture 2030, seeks to combat climate change by putting forth specific building energy reduction targets for those adopting the Challenge. Using fossil fuel-generated site energy from 2001 surveys as a baseline, the current reduction goal at the time of this writing is $60 \%$, with the goals of $70 \%$, $80 \%, 90 \%$, and carbon neutral to be achieved by 2015, 2020,2025, and 2030, respectively (Table 6). Buildings are expected to achieve these goals using a combination of low energy design strategies, the generation of on-site renewable energy, and purchase of off-site renewable energy.

Table 6. 2030 Challenge Site Energy Reduction Goals

\begin{tabular}{|c|c|}
\hline Year & $\begin{array}{l}\text { Fossil Fuel Site Energy Reduction Goal from } \\
\text { 2001 Surveys }\end{array}$ \\
\hline Today (2012) & $60 \%$ \\
\hline 2015 & $70 \%$ \\
\hline 2020 & $80 \%$ \\
\hline 2025 & $90 \%$ \\
\hline 2030 & Carbon neutral \\
\hline
\end{tabular}

Figure 20 includes both single-family and multifamily 2030 Challenge metrics. The multifamily designation applies to both the Somerville Triple Decker and the Belmont Two Family.

\section{Source Energy Use Before and After DERs}

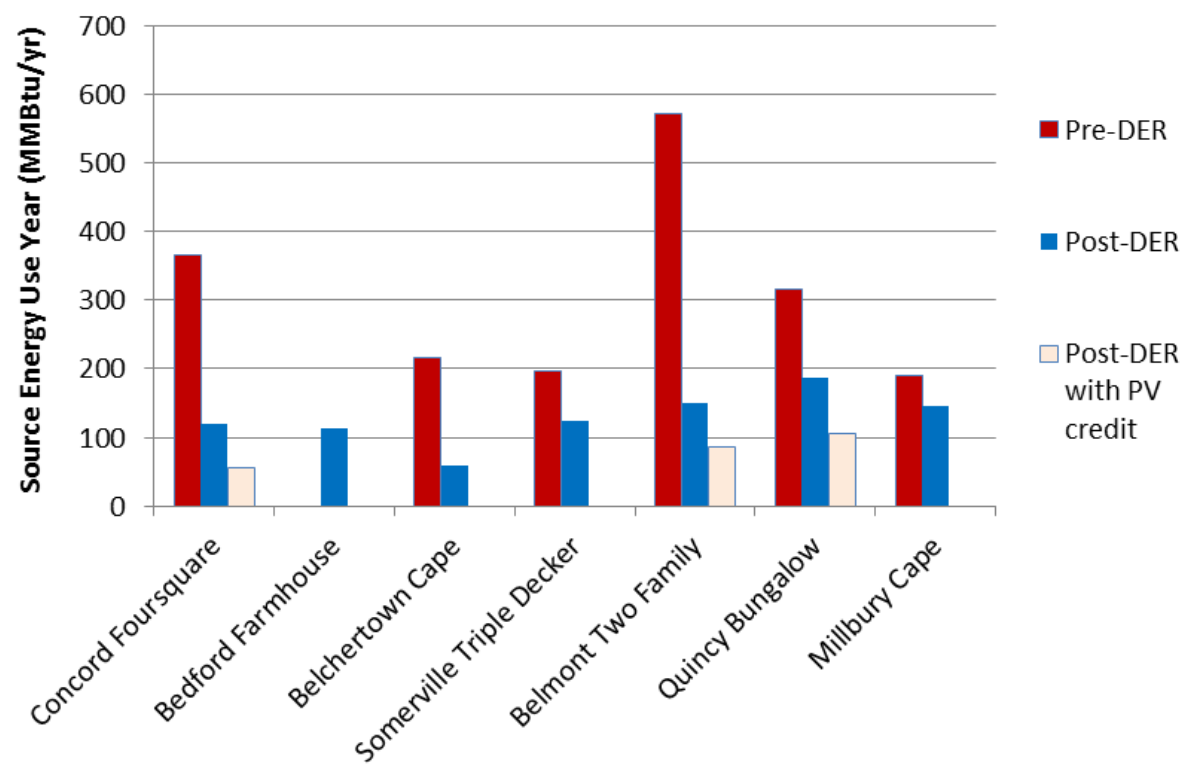

Figure 19. Source energy use before and after the retrofits for each of the 7 homes 


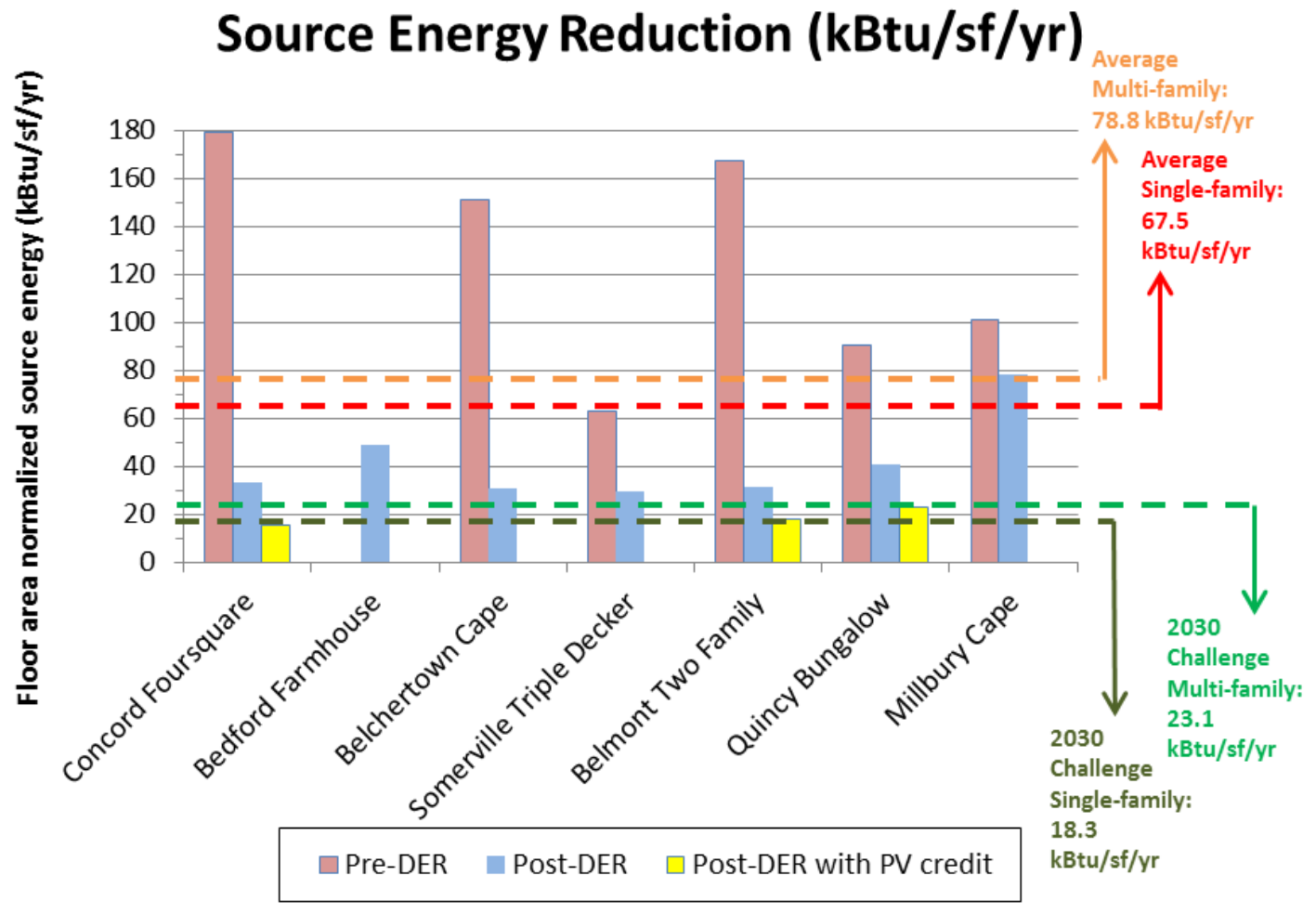

Figure 20. Source energy use per conditioned area (energy use index) compared to 2030 Challenge metrics ( $60 \%$ energy reduction)

As shown in Figure 19 and Figure 20, the Millbury Cape has the highest post-retrofit source energy use per square foot of conditioned area. The energy performance of this home compared to others is worse than anticipated; however, there are several possible factors contributing to the higher normalized energy use. One factor is that it is the smallest home in the group at only $1,868 \mathrm{ft}^{2}$, including the $768 \mathrm{ft}^{2}$ basement (Table 2). Although the Belchertown Cape is similarly sized at $1,907 \mathrm{ft}^{2}$, including the basement, it is known that the owners are extremely frugal with energy use and tolerant of more extreme interior temperatures, as described in Section 3.3.3. Smaller homes tend to have proportionally higher energy use indices because of their increased surface area to volume ratio and issues such as the fact that essentially the same appliances and miscellaneous loads are contained within a smaller space. The Millbury Cape's source energy reduction is also confused by the fact that there was a fuel switch from oil and pellets to heat pump electricity and pellets. Wood pellets are considered to have a source to site energy ratio of 1; the factor used for electricity is 3.34 (Figure 18). Additionally, the Millbury Cape homeowners added central air conditioning in the summer. The window units they used previously may have been less frequently operated. Additional investigation and continued monitoring are needed to fully understand the long-term performance of the home.

As expected, the three homes with PV systems achieve the lowest normalized source energy savings. The post-retrofit data available so far show that both the Concord Foursquare and the Belmont Two Family achieve the stringent 2030 Challenge $60 \%$ reduction goal. However, it should be noted that both of these homes' pre-retrofit use was generated by energy models as 
only post-retrofit data were available. The single-family Quincy Bungalow (at $23 \mathrm{kBtu} / \mathrm{ft}^{2} / \mathrm{yr}$ ) exceeds the $60 \%$ reduction goal by only $20 \%$.

Each home's detailed utility tracking and models used to create these summary comparisons are presented in the following sections. Additionally, parametric models showing the estimated effect of each retrofit upgrade are presented when available. Modeling was performed using either the Energy Gauge USA or BEopt software packages.

\subsubsection{Concord Foursquare}

The Concord Foursquare renovation was completed in December 2007; the 4.9-kW PV array was operational by May 2009. The homeowner did not live in the building prior to the retrofit; pre-retrofit utility data were unavailable. However, an Energy Gauge model estimating the energy use of the pre-retrofit state was created (Table 7). An attempt was made to match the occupancy and internal loads of the pre-retrofit model to post-retrofit conditions. Modeled energy use was compared to that of the 2008 BA Benchmark, the post-retrofit model, and the real post-retrofit building (Figure 21). When the pre-retrofit model is compared to available postretrofit data, a $67 \%$ source energy saving is achieved (Table 5). This saving increases to $85 \%$ when the benefit of the PV system is included.

Table 7. Concord Foursquare Pre- and Post-Retrofit Summary

\begin{tabular}{|c|c|c|}
\hline Parameter & $\begin{array}{c}\text { Pre-Retrofit } \\
\text { (2008 BA Benchmark) }\end{array}$ & Post-Retrofit \\
\hline Roof/Ceiling & $\begin{array}{l}\text { Ceiling nominal R-value R-38 } \\
\text { (0.030 U value) }\end{array}$ & $\begin{array}{l}\text { Unvented attic: R- } 60 \text { with } 4 \text {-in. } \\
\text { rigid foam on the exterior and } 5 \text {-in. } \\
\text { high density sprayed polyurethane } \\
\text { foam to the underside of the roof } \\
\text { sheathing }\end{array}$ \\
\hline $\begin{array}{l}\text { Above-Grade } \\
\text { Walls }\end{array}$ & $\begin{array}{l}\text { Wood frame wall nominal R- } \\
\text { value R-19 or R-13+5 }\end{array}$ & $\begin{array}{l}\text { R-41 with blown cellulose cavity } \\
\text { insulation and } 4 \text { in. of rigid foam on } \\
\text { the exterior }\end{array}$ \\
\hline Windows & $\mathrm{U}=0.89 \mathrm{SHGC}^{*}=0.64$ & $\begin{array}{l}\text { Double glazed, low-e, argon filled: } \\
\qquad \mathrm{U}=0.33, \mathrm{SHGC}=0.33\end{array}$ \\
\hline Infiltration & $12 \mathrm{ACH} 50$ & $3.4 \mathrm{ACH} 50$ \\
\hline Foundation & $\begin{array}{l}\text { Basement wall R-10 cont/R- } \\
13 \text { batt ( } 0.065 \mathrm{U} \text { value })\end{array}$ & $\begin{array}{l}\text { Foundation Walls: R-20 walls with } \\
\text { 4-in. high density sprayed } \\
\text { polyurethane foam. Slab: R-10; 2- } \\
\text { in. XPS insulating sheathing }\end{array}$ \\
\hline $\begin{array}{l}\text { Heating and } \\
\text { Cooling }\end{array}$ & $\begin{array}{l}\text { 78\% AFUE** gas furnace } 13 \\
\text { SEER } * * * \text { split system air } \\
\text { conditioner }\end{array}$ & $\begin{array}{l}92 \% \text { AFUE sealed combustion gas } \\
\text { boiler in conditioned space. } 13 \\
\text { SEER split system air conditioner }\end{array}$ \\
\hline Ventilation & $\begin{array}{c}\text { Supply only,50 CFM@33\% } \\
\text { duty cycle }\end{array}$ & $\begin{array}{l}\text { Supply only, 50 CFM@33\% duty } \\
\text { cycle, electronic control module } \\
\text { motor }\end{array}$ \\
\hline
\end{tabular}




\begin{tabular}{c|c|c}
\hline Parameter & $\begin{array}{c}\text { Pre-Retrofit } \\
\mathbf{( 2 0 0 8} \mathbf{~ B A} \text { Benchmark) }\end{array}$ & Post-Retrofit \\
\hline DHW $^{\dagger}$ & $\begin{array}{c}0.54 \mathrm{EF}^{\dagger \dagger} \text { conventional tank } \\
\text { water heater }\end{array}$ & 0.8 EF side-arm storage tank \\
\hline Lighting & $10 \% \mathrm{CFLs}^{\dagger \dagger}$ & $100 \%$ ENERGY STAR CFLs \\
\hline $\begin{array}{c}\text { Appliances } \\
\text { Site-Generated } \\
\text { Power }\end{array}$ & Conventional & ENERGY STAR \\
\hline
\end{tabular}

* Solar heat gain coefficient

** Annual fuel utilization efficiency

$* * *$ Seasonal energy efficiency ratio

${ }^{\dagger}$ Energy factor

${ }^{\dagger}$ Domestic hot water

${ }^{\dagger \dagger}$ Compact fluorescent lamps

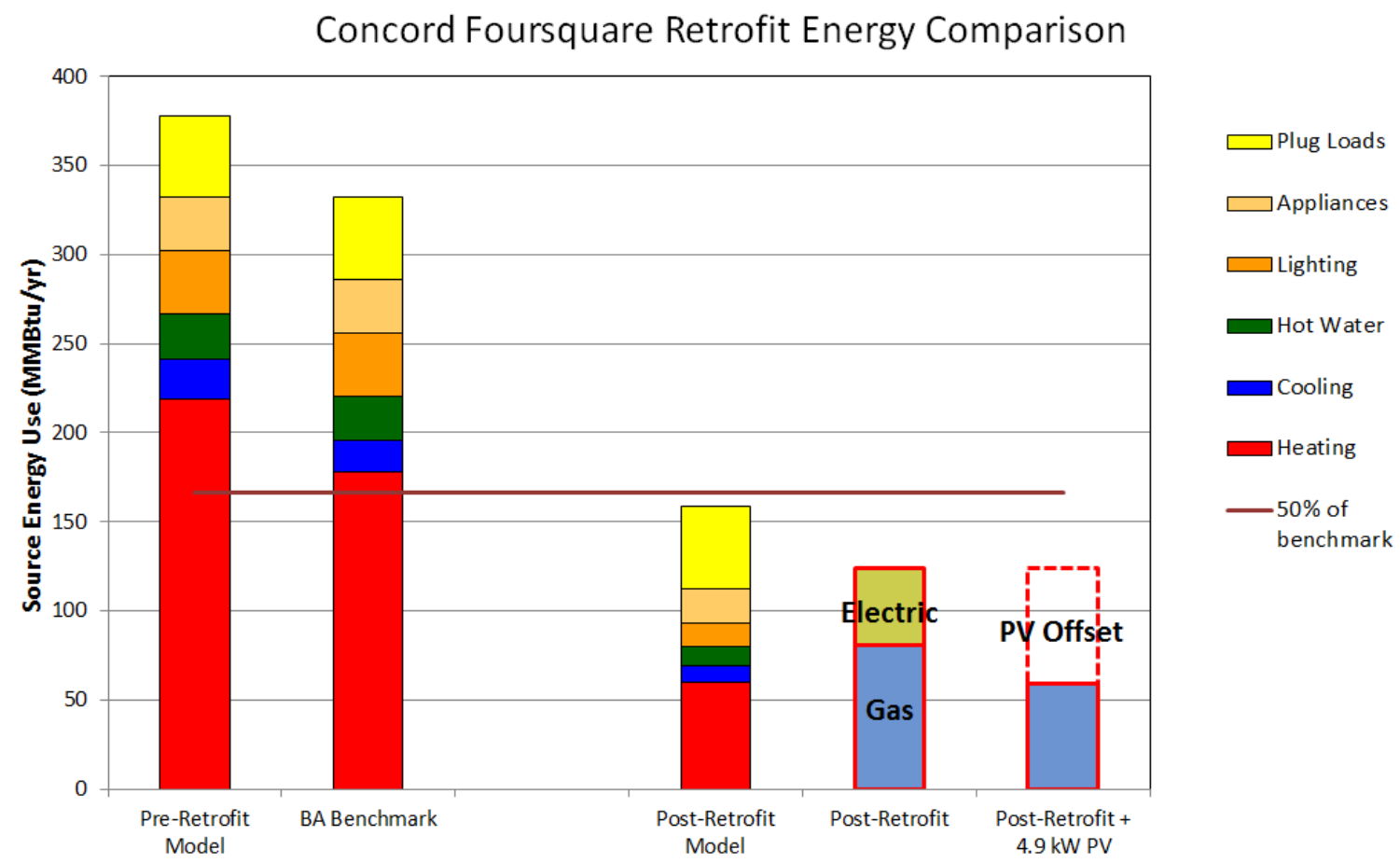

Figure 21. Concord Foursquare energy modeling comparison 


\section{Concord Foursquare Electrical Consumption \& PV Production}

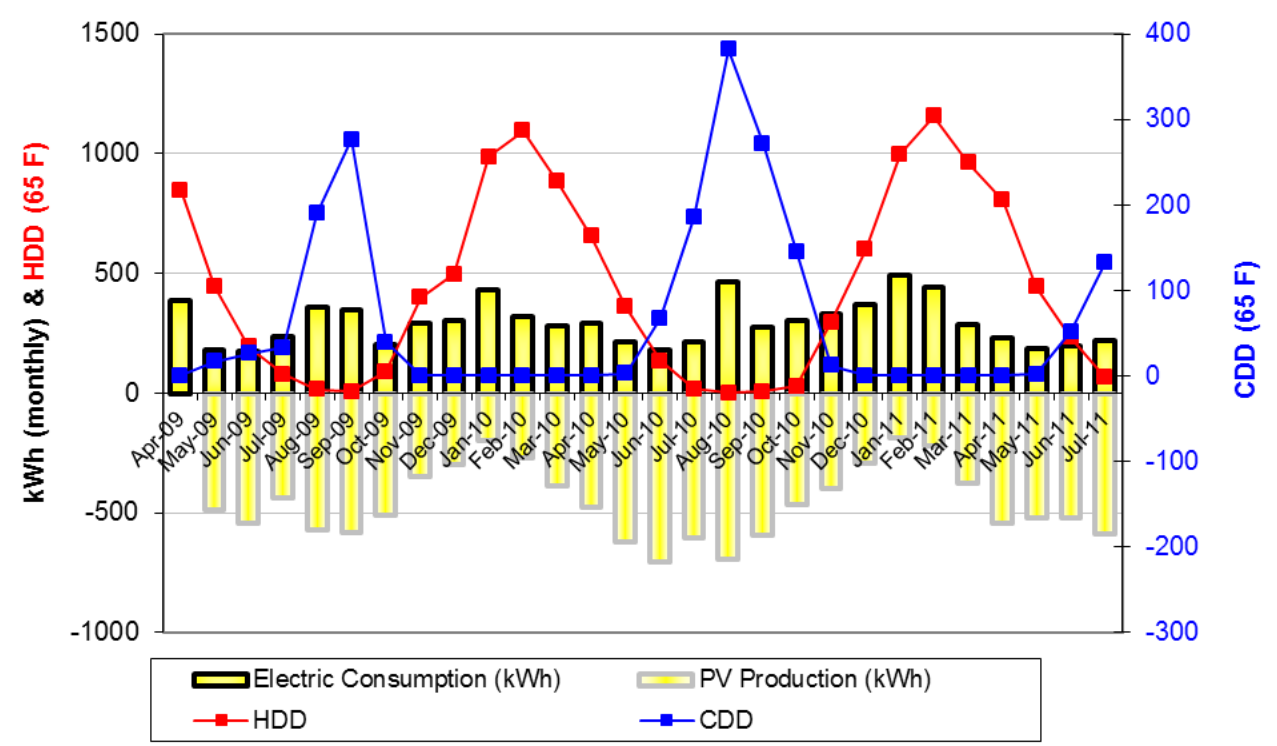

Figure 22. Monthly electricity use and generation of the Concord Foursquare

\section{Concord Foursquare Natural Gas Use}

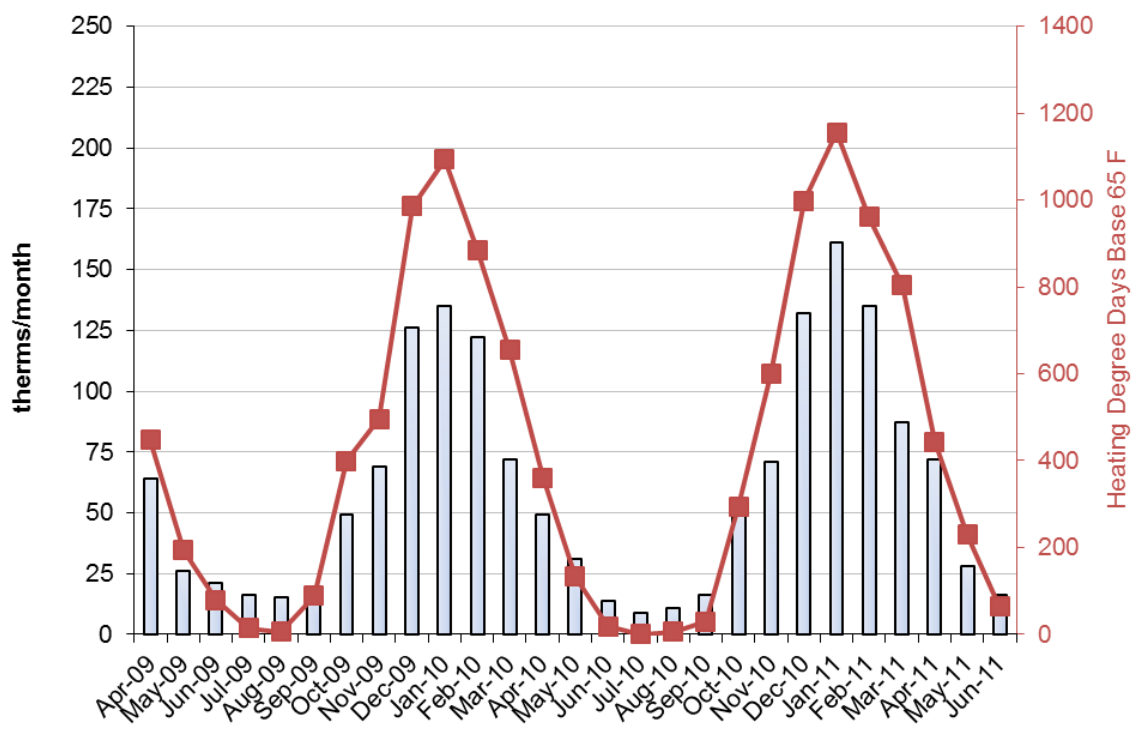

ऍtherms $\rightarrow-H D D$

Figure 23. Monthly gas use of the Concord Foursquare

BSC will continue to monitor this home to gain a better understanding of the long-term energy performance over many years. 


\subsubsection{Bedford Farmhouse}

As the Bedford Farmhouse had already been unoccupied for a period of time and partially demolished before BSC became involved in the project, it was not possible to collect pre-retrofit utility data or build an accurate energy model to represent the pre-retrofit state. However, a model of a 2008 BA Benchmark building was created in order to show the steps of a parametric energy reduction to the post-retrofit design (Figure 24). Table 8 shows the modeling inputs. The annual source energy use predicted by the model (125 MMBtu/yr) in fact exceeded the actual source energy use of the home (113 MMBtu/yr) during the available post-retrofit analysis period (Table 5).

Table 8. Bedford Farmhouse Pre- and Post-Retrofit Summary

\begin{tabular}{|c|c|c|}
\hline Parameter & $\begin{array}{c}\text { Pre-Retrofit } \\
\text { (2008 BA Benchmark) }\end{array}$ & Post-Retrofit \\
\hline Roof/Ceiling & Nominal R-34 & $\begin{array}{l}\text { Unvented attic: Nominal R-56 } \\
\text { with 4-in. foil-faced } \\
\text { polyisocyanurate insulating } \\
\text { sheathing and R-30 unfaced } \\
\text { fiberglass batt insulation in rafter } \\
\text { bays }\end{array}$ \\
\hline Above-Grade Walls & Nominal R-20 & Nominal R-40 \\
\hline Windows & $\mathrm{U}=0.46, \mathrm{SHGC}=0.50$ & $\begin{array}{c}\text { Double-glazed, low-E vinyl } \\
\text { windows: } \mathrm{U}=0.35, \mathrm{SHGC}=0.29\end{array}$ \\
\hline Infiltration & $6.9 \mathrm{ACH} 50$ & $6.1 \mathrm{ACH} 50$ \\
\hline Foundation & Basement wall R-9.2 & Basement walls R-13 ccSPF, \\
\hline Heating and Cooling & $\begin{array}{l}\text { 78\% AFUE gas furnace } 10 \\
\text { SEER air conditioner }\end{array}$ & $\begin{array}{l}95 \% \text { AFUE gas furnace No air } \\
\text { conditioner installed }\end{array}$ \\
\hline Ventilation & $\begin{array}{c}\text { Supply only, 50 CFM @ 33\% } \\
\text { duty cycle }\end{array}$ & $\begin{array}{l}\text { Central-fan-integrated supply } \\
\text { (CFIS) ventilation }\end{array}$ \\
\hline DHW & $\begin{array}{l}0.54 \text { EF conventional tank } \\
\text { gas water heater }\end{array}$ & $\begin{array}{l}0.82 \mathrm{EF} \text { on-demand gas water } \\
\text { heater }\end{array}$ \\
\hline Lighting & $14 \%$ CFLs & 90\% ENERGY STAR CFLs \\
\hline Appliances & BA Benchmark conventional & ENERGY STAR appliances \\
\hline Site-Generated Power & None & None \\
\hline
\end{tabular}




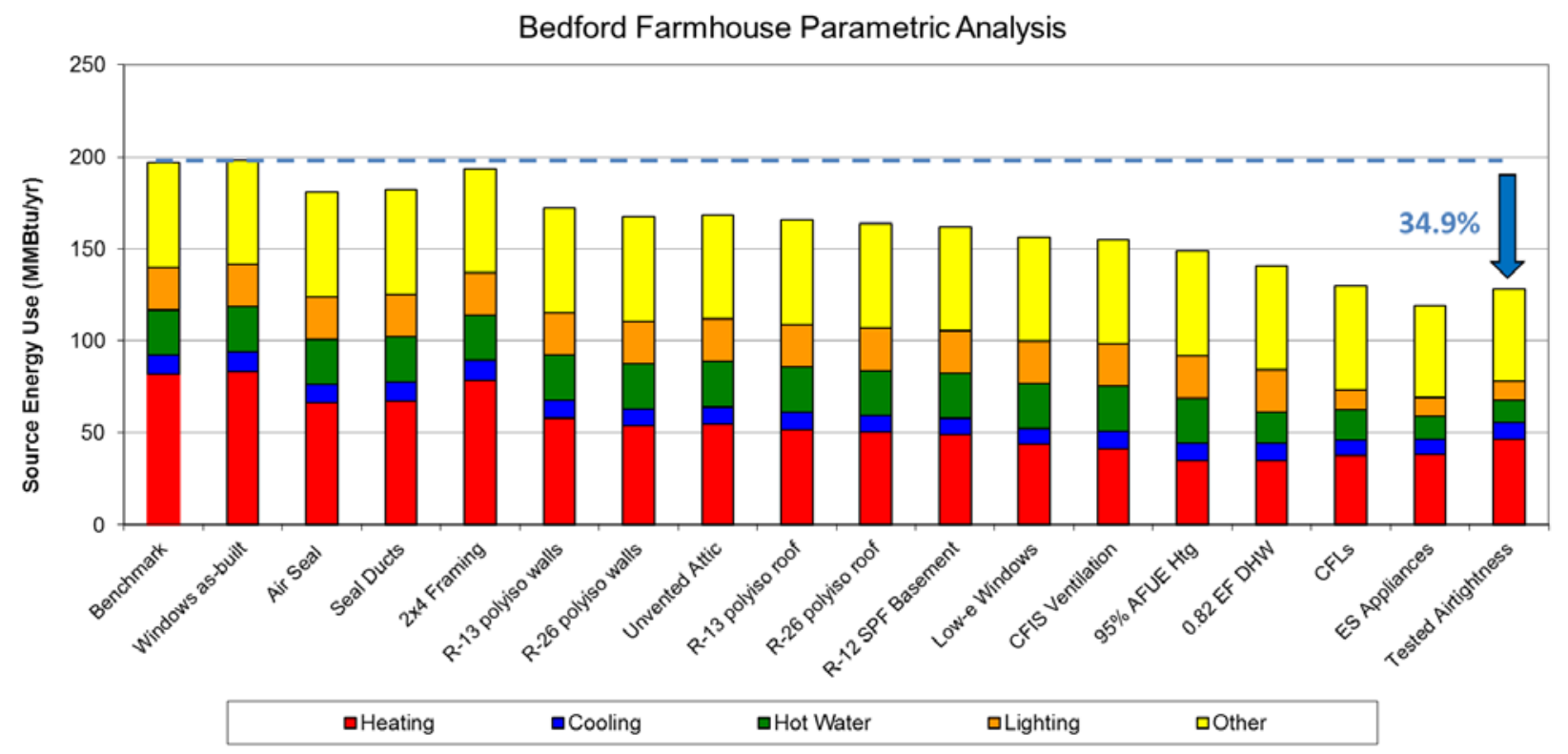

Figure 24. Parametric energy modeling of the Bedford Farmhouse

Utility bills from the completed Bedford Farmhouse have been monitored by BSC since April 2009 (Figure 25 and Figure 26). Trending shows typical seasonal variation. More than a year of post-move-in data was available, enabling initial evaluation of post-retrofit performance.

\section{Bedford Farmhouse Electrical Consumption}

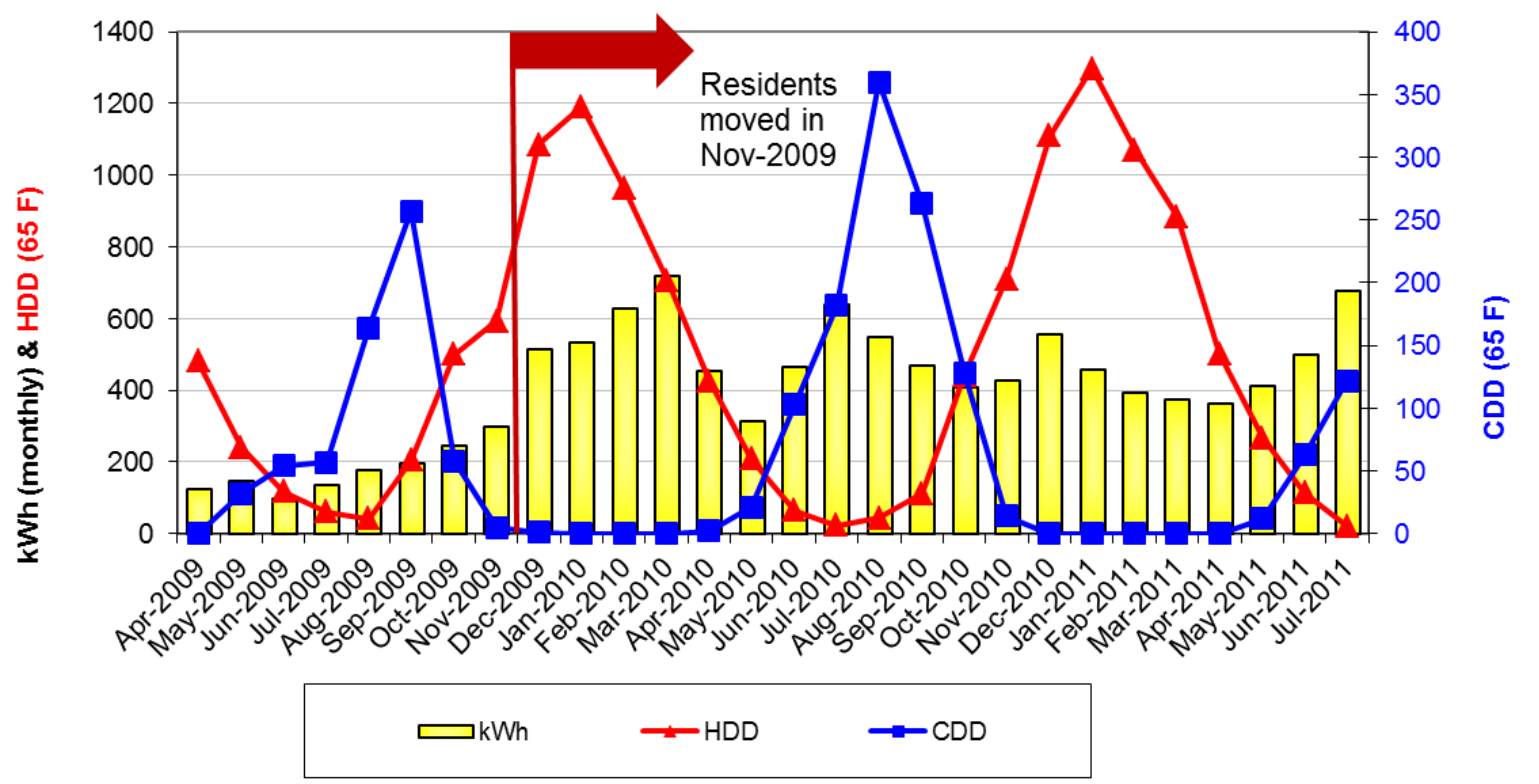

Figure 25. Electricity use monitoring of the Bedford Farmhouse 


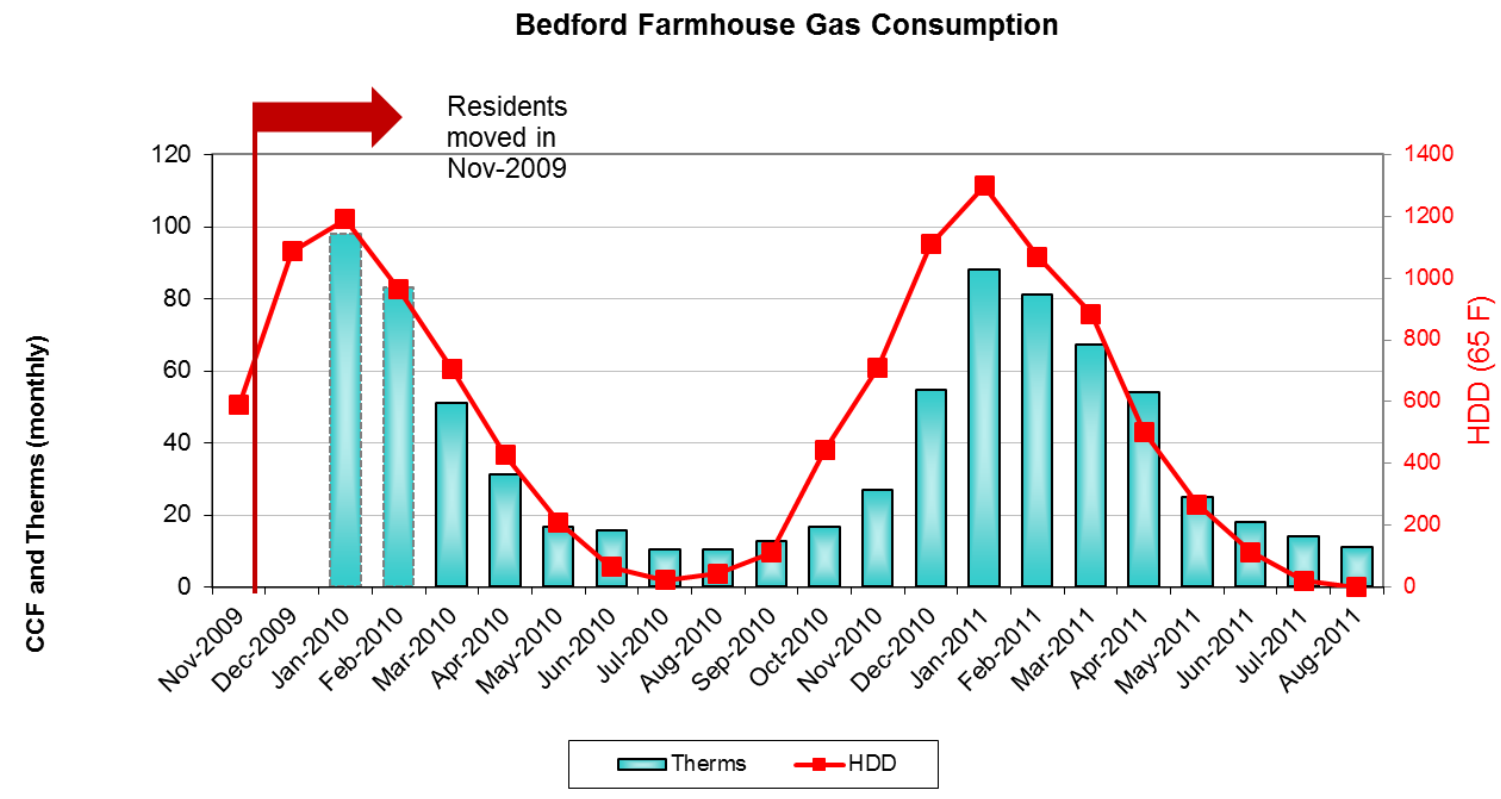

Figure 26. Gas consumption monitoring of the Bedford Farmhouse

Through this project, HfHGL has demonstrated that high performance housing is achievable even in the face of the triple challenge of retrofit, affordable housing, and volunteer labor. The projected energy performance represents a significant improvement relative to typical U.S. housing stock and compared to code-built new construction built by building professionals.

BSC developed many construction details to allow this project to achieve its high performance objects. Through the challenges of implementing an effective air barrier, BSC has identified more robust, less workmanship-dependent systems to ease the achievement of high performance on successive projects (Ueno 2010).

\subsubsection{Belchertown Cape}

The residents of the Belchertown Cape were remarkably frugal with energy use while enduring what most people would consider extreme discomfort and inconvenience. The pre-retrofit home had no air conditioning, mechanical ventilation, or clothes washer and dryer. More significant, however, was the condition of the home during the heating season. Approximately seven cords of wood were burned per year. During cold winter periods, the occupants primarily lived in the kitchen area, reporting that areas furthest from the wood stove could drop below $32^{\circ} \mathrm{F}$. This extreme temperature drop was permitted to occur because the homeowners knew that all plumbing was located within a couple of yards of the wood stove. In the basement, where the standing water would often freeze, an electric heater was used to raise the temperature near the plumbing a few degrees above freezing. Significant spikes from electric heating in the basement can be observed in the graph of electricity use (Figure 28). Propane was used for water heating only (Figure 29).

As part of the retrofit, an efficient propane-fired furnace was installed to provide space heating to replace the wood-burning stove. A highly effective HRV was added to provide ventilation in the newly airtightened home. Coils were also installed for connection to an air source heat pump 
should the owners choose to install one in the future. Post-retrofit electricity use does not reflect air conditioning. An ENERGY STAR clothes washer and dryer were installed in the home as well. Figure 28 shows that the electricity spikes from the basement electric heater are absent in the post-retrofit home.

The energy model (Figure 27) predicted a lower source energy $(51.6 \%)$ reduction than shown by the utility information available so far (73\%). Table 9 shows the modeling inputs. The difference can be partially accounted for by the fact that the model could not fully capture the energy use and inefficiency of the wood-burning stove, or the fact that the pre-retrofit home was not maintaining comfortable temperatures throughout the house. Additionally, the extremely high pre-retrofit infiltration rate (approximately $58 \mathrm{ACH} 50$ ) was not included in the Benchmark preretrofit model.

Table 9. Belchertown Cape Pre- and Post-Retrofit Modeling Summary

\begin{tabular}{|c|c|c|}
\hline Parameter & $\begin{array}{c}\text { Pre-Retrofit } \\
\text { (2010 BA Benchmark) }\end{array}$ & Post-Retrofit \\
\hline Roof/Ceiling & Nominal R-25 & $\begin{array}{l}\text { Unvented roof, framing cavity filled } \\
\text { with R-56 medium density spray } \\
\text { foam insulation }\end{array}$ \\
\hline $\begin{array}{l}\text { Above-Grade } \\
\text { Walls }\end{array}$ & Nominal R-23 & $\begin{array}{l}\text { Framing cavity filled with R-32 } \\
\text { medium-density spray foam }\end{array}$ \\
\hline Windows & $\mathrm{U}=0.39, \mathrm{SHGC}=0.28$ & $\begin{array}{c}\text { Storm windows over double-glazed, } \\
\text { low-E, wood-framed windows: } \mathrm{U}= \\
0.25, \mathrm{SHGC}=0.52\end{array}$ \\
\hline Infiltration & $8.7 \mathrm{ACH} 50$ & $1.9 \mathrm{ACH} 50$ \\
\hline Floor/Foundation & $\mathrm{R}-19$ in floor joists & $\begin{array}{l}\text { Conditioned basement, } \\
\text { Approximately R- } 25 \text { medium density } \\
\text { spray foam on basement walls, R-10 } \\
\text { XPS under the slab }\end{array}$ \\
\hline $\begin{array}{l}\text { Heating and } \\
\text { Cooling }\end{array}$ & $\begin{array}{l}78 \% \text { AFUE gas furnace } 10 \\
\text { SEER air conditioner }\end{array}$ & $\begin{array}{l}96.7 \% \text { AFUE sealed combustion } \\
\text { propane furnace in conditioned } \\
\text { space, no air conditioning }\end{array}$ \\
\hline Ventilation & $\begin{array}{l}\text { Balanced ventilation, } 44.3 \text { CFM } \\
\text { @33\% duty cycle }\end{array}$ & $\begin{array}{c}\text { HRV, 44.3 CFM@33\% duty cycle, } \\
\text { 74\% recovery effectiveness }\end{array}$ \\
\hline DHW & $\begin{array}{l}0.54 \text { EF conventional tank gas } \\
\text { water heater }\end{array}$ & $\begin{array}{l}0.86 \mathrm{EF} \text { on-demand propane-fired } \\
\text { water heater }\end{array}$ \\
\hline Lighting & $14 \%$ CFLs & 100\% ENERGY STAR CFLs \\
\hline Appliances & BA Benchmark conventional & ENERGY STAR appliances \\
\hline $\begin{array}{l}\text { Site-Generated } \\
\text { Power }\end{array}$ & None & None \\
\hline
\end{tabular}




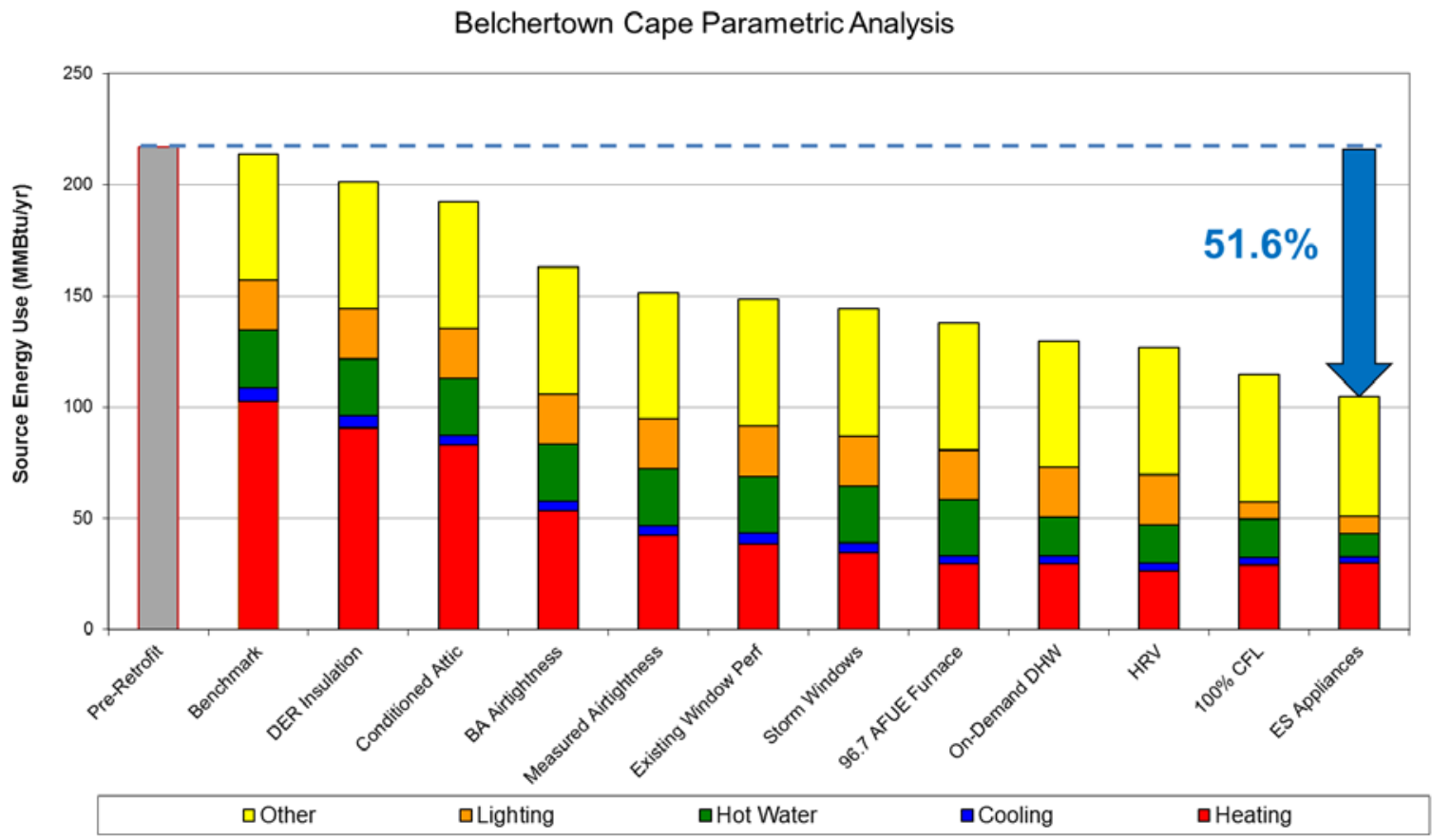

Figure 27. Parametric energy analysis of the Belchertown Cape

Figure 28 and Figure 29 show electricity use and propane delivery before and after the retrofit. Please note that in Figure 28, use data were available from 2006 but heating degree day (HDD) and cooling degree day (CDD) data from more than three years ago were not available. The graph of propane delivery (Figure 29) represents the dates and quantities of delivery. Gallons delivered during a particular month were not necessarily used up during that month. Use data of the seven cords of wood for winter heating were not available by month. As shown, the extreme spikes of winter electricity use (representing the basement space heater) were absent in the postretrofit period. Post-retrofit propane use increased from $104 \mathrm{gal} / \mathrm{yr}$ to $357 \mathrm{gal} / \mathrm{yr}$; however, the efficient propane-fired furnace was able to replace the wood stove and maintain comfortable temperatures throughout the house. An overall significant reduction of source energy use was achieved and occupant comfort and convenience increased significantly. 


\section{Belchertown Cape Electricty Consumption}

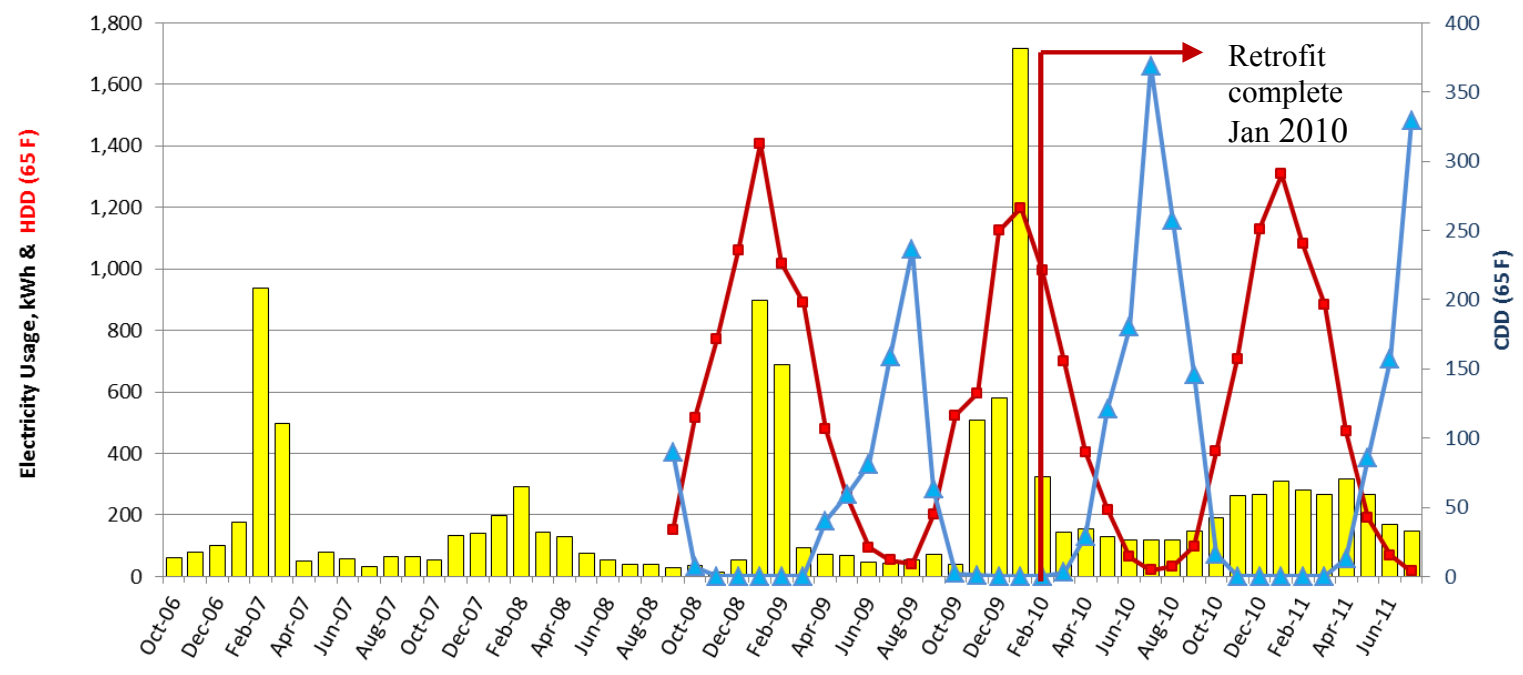

$\square \mathrm{kWh} \rightarrow \mathrm{HDD} \longrightarrow \mathrm{CDD}$

Figure 28. Electricity consumption of the Belchertown Cape

\section{Belchertown Cape Propane Delivery}

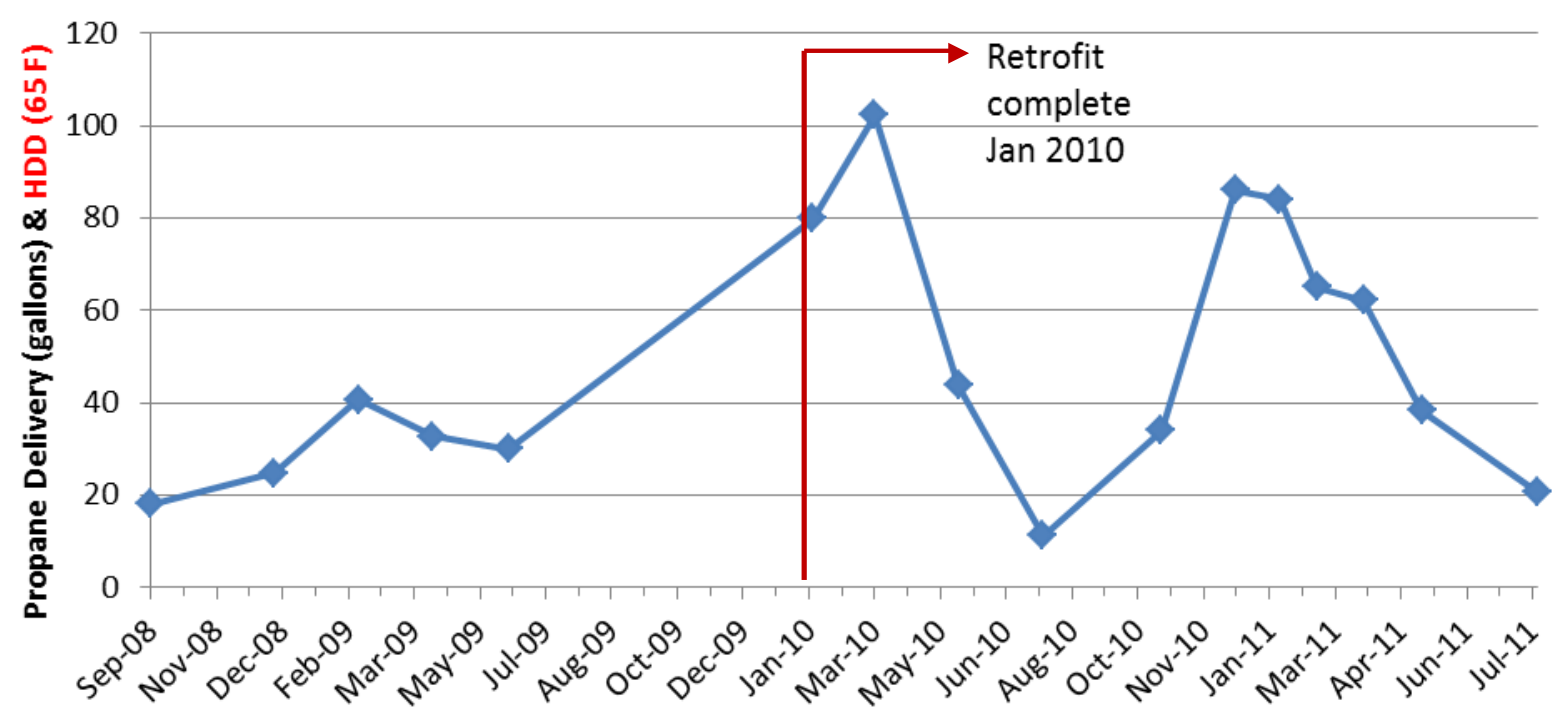

Figure 29. Propane delivery at the Belchertown Cape

\subsubsection{Somerville Triple Decker}

The Somerville Triple Decker was modeled in BEopt, even though the current version of the software is not designed to be used for multifamily homes. Single-family assumptions are used, so a model may underestimate the energy use for a multifamily building because of the multiple kitchens, bathrooms, and assumptions about occupancy based on the number of bedrooms. 
Factors such as differences in set point temperatures for different apartments could not be fully captured. The modeling inputs are shown in Table 10.

Table 10. Somerville Triple Decker Pre- and Post-Retrofit Modeling Summary

\begin{tabular}{|c|c|c|}
\hline Parameter & Pre-Retrofit & Post-Retrofit \\
\hline Roof/Ceiling & $\begin{array}{l}\text { R-14 cellulose between roof } \\
\text { rafters }\end{array}$ & $\begin{array}{l}\text { R-55 with 8-in. open cell spray foam in } \\
\text { rafter cavities and 4-in. foil-faced } \\
\text { polyisocyanurate }\end{array}$ \\
\hline $\begin{array}{l}\text { Above-Grade } \\
\text { Walls }\end{array}$ & Uninsulated, wood-framed & $\begin{array}{l}\text { R-41 blown-cellulose cavity insulation } \\
\text { and 4-in. foil-faced polyisocyanurate }\end{array}$ \\
\hline Windows & $\mathrm{U}=0.33, \mathrm{SHGC}=0.56$ & $\begin{array}{l}\text { Fiberglass units with suspended film: } \mathrm{U} \\
\quad=0.19, \mathrm{SHGC}=0.24\end{array}$ \\
\hline Infiltration & $16.5 \mathrm{ACH} 50$ & $3.5 \mathrm{ACH} 50$ \\
\hline Floor/Foundation & Uninsulated & $\begin{array}{l}\text { R-20 basement walls, } 4 \text {-in. high density } \\
\text { sprayed polyurethane foam }\end{array}$ \\
\hline $\begin{array}{l}\text { Heating and } \\
\text { Cooling }\end{array}$ & $\begin{array}{l}\text { Forced air, } 84 \% \text { AFUE gas } \\
\text { furnace, with leaky, } \\
\text { uninsulated ducts. One floor } \\
\text { had hydronic heating, but } \\
\text { multiple system types could } \\
\text { not be selected in BEopt } \\
\text { Old window air conditioners } \\
\text { (10 SEER) }\end{array}$ & $\begin{array}{l}\text { Gas-fired Phoenix Versa Hydro used for } \\
\text { hydronic heating and DHW. } \\
\text { Approximated in BEopt using } 90 \% \\
\text { efficient gas-fired hydronic system } \\
\text { Old window air conditioners (10 SEER) }\end{array}$ \\
\hline Ventilation & Bathroom exhausts only & $\begin{array}{l}80 \% \text { effective HRVs for each of the } \\
\text { three apartments }\end{array}$ \\
\hline DHW & Modeled as $0.80 \mathrm{EF}$, gas-fired & Modeled as $0.80 \mathrm{EF}$, gas-fired \\
\hline Lighting & 90\% ENERGY STAR CFLs & 100\% ENERGY STAR CFLs \\
\hline Appliances & Conventional appliances & Conventional appliances \\
\hline $\begin{array}{l}\text { Site-Generated } \\
\text { Power }\end{array}$ & None & None \\
\hline
\end{tabular}




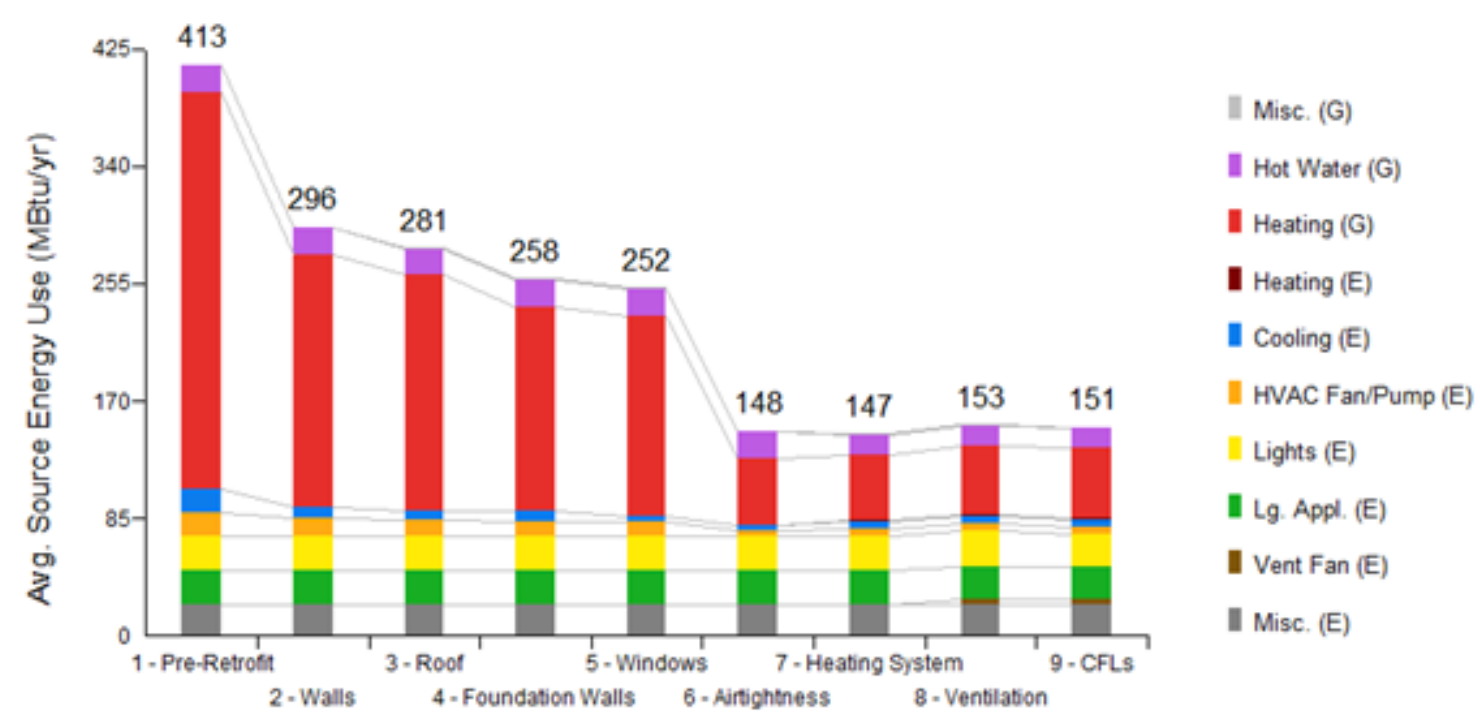

Figure 30. Parametric energy modeling of the Somerville Triple Decker

BEopt modeling results predict a yearly source energy reduction of $63 \%$ from the retrofit. This is in contrast to the $36 \%$ reduction in source energy shown by the pre- and post-retrofit data available (Table 5). As shown in the table and in Figure 31 and Figure 32, a substantial reduction is heating energy is observed, but electricity use increases slightly from May through July. It should be kept in mind that the old window units used for air conditioning were not replaced during the retrofit. Observing lower utility bills, it is possible that occupants increased use of the window air conditioners ("take-back"). However, as reported in the occupant survey, homeowners experienced significantly higher comfort during hot periods of the year. Utility use of the Somerville Triple Decker should continue to be monitored in order to better understand long-term performance of the building.

As observed in Figure 33, the model in all cases overpredicts energy use compared to the values reported in occupant utility bills. In the post-retrofit case, the model overpredicts electricity use by $62 \%$, gas use by $24 \%$, and total source energy by $45 \%$. In the pre-retrofit case, the model overpredicts electricity use by $43 \%$, gas use by $67 \%$, and total source energy by $62 \%$. BSC and other practitioners have frequently observed such drastic modeling overpredictions of gas use in uninsulated pre-retrofit homes. The possible reasons for this observed discrepancy are an area of ongoing interest for BSC. In this case, heating was reported to have been used very sparingly before the retrofit, so average heating set point temperatures may have been significantly lower than modeled. 


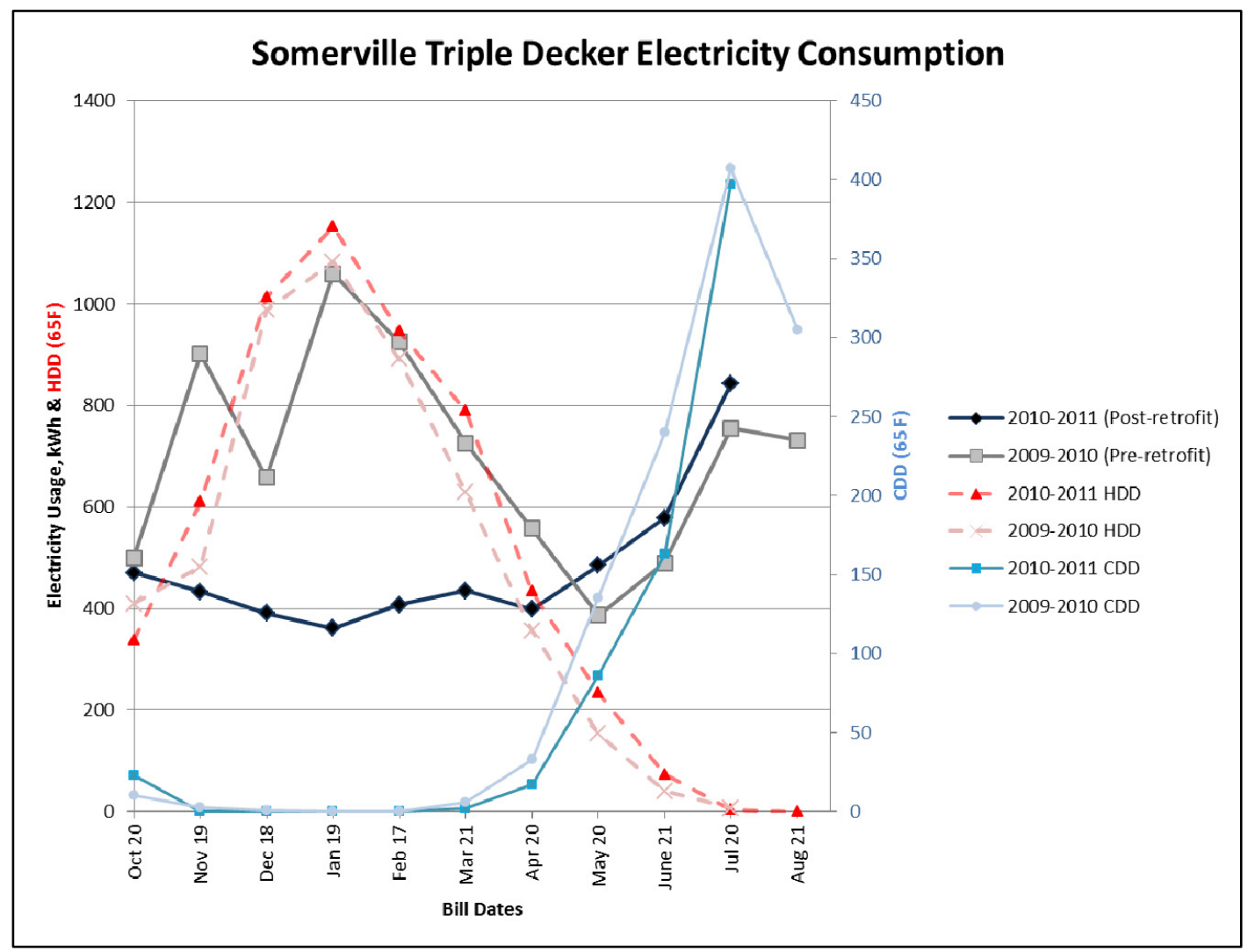

Figure 31. Somerville Triple Decker Electric consumption

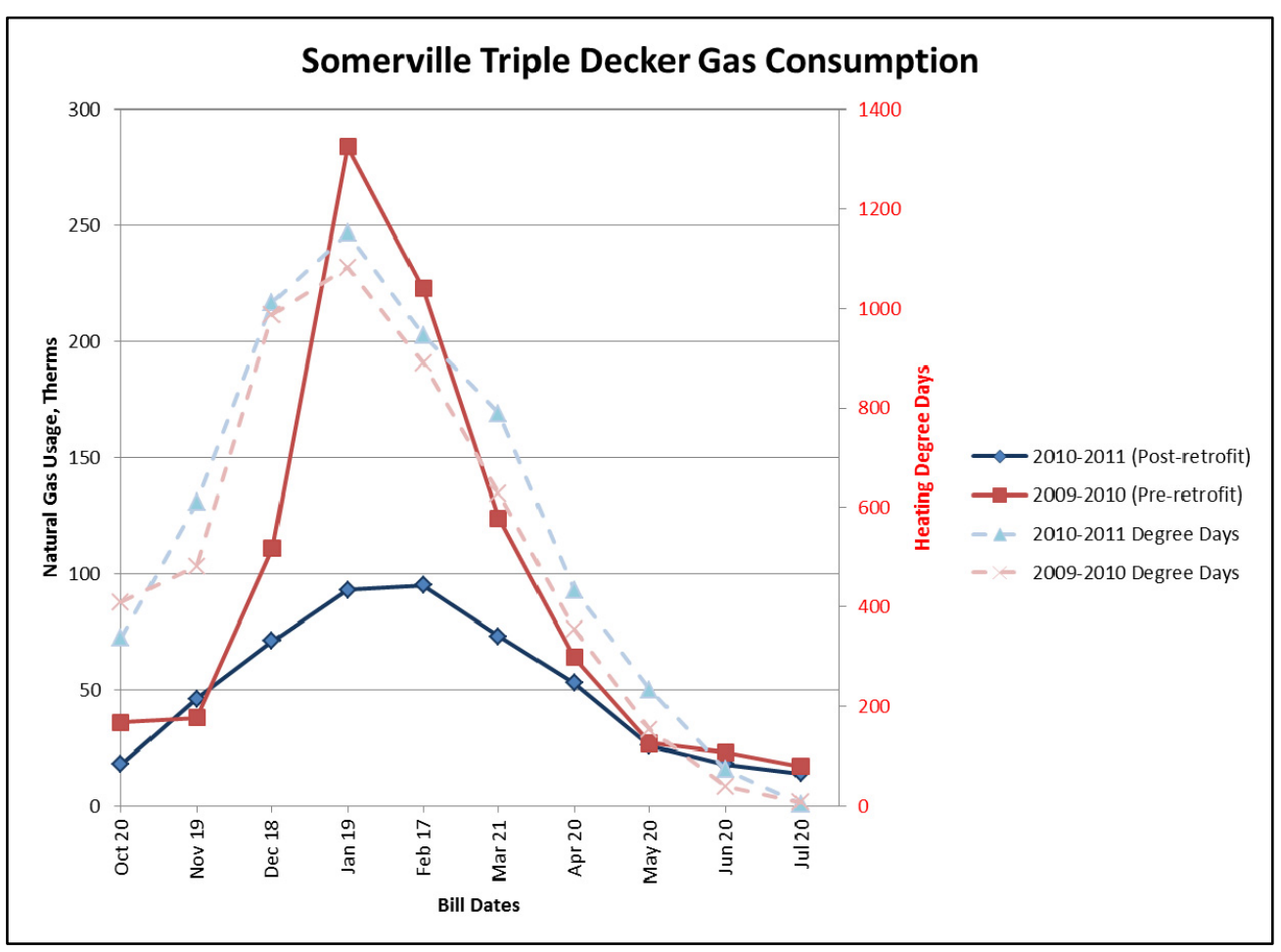

Figure 32. Somerville Triple Decker Gas consumption 


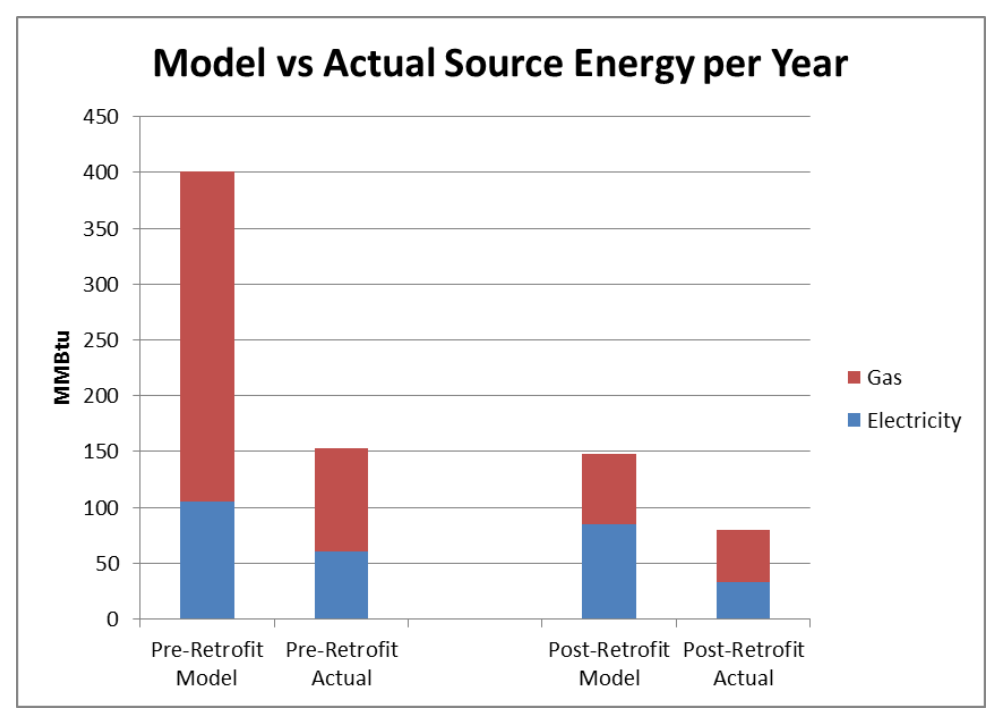

Figure 33. Somerville Triple Decker pre- and post-retrofit source energy breakdown

\subsubsection{Belmont Two Family}

Because the Belmont Two Family homeowners purchased the home immediately before the retrofit began, pre-retrofit utility use was not available. However, a model of the pre-retrofit state was created to show the incremental upgrades from the starting point (Figure 34) and to generate the pre-retrofit energy use used for comparison in Table 5. The 74\% energy saving (before PV) calculated by comparing post-retrofit utility use to a model of the pre-retrofit state is likely to be higher than reality, as BSC and others have previously observed the tendency of models to overpredict the energy use of pre-retrofit homes with little or no insulation (Table 11). One possible cause of this is that the model will use enough energy to maintain the home at comfortable temperatures even though the real homeowners may have used heating very sparsely and experienced some rooms to be much colder than others in winter.

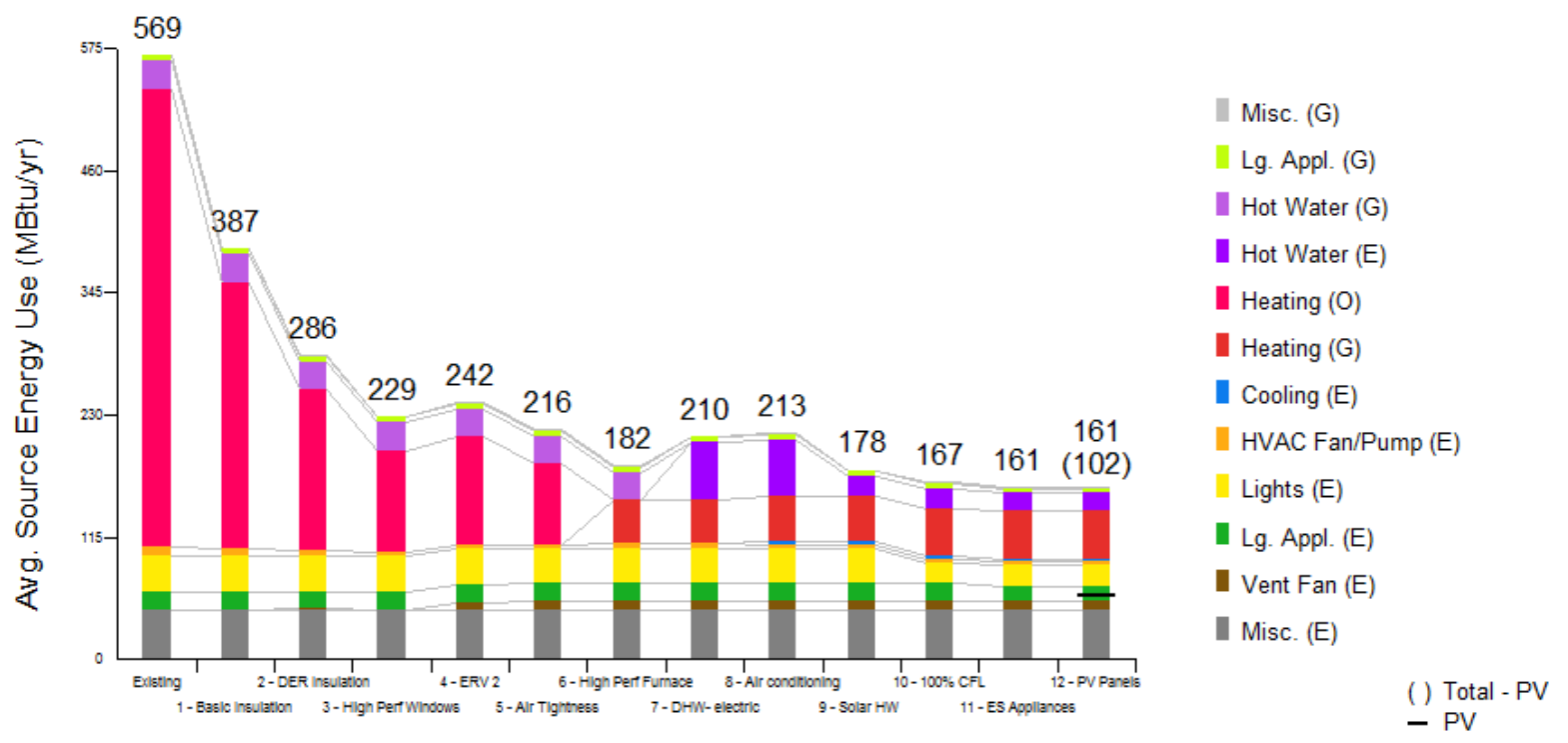

Figure 34. Belmont Two Family parametric energy analysis 
Table 11. Belmont Two Family Pre- and Post-Retrofit Modeling Summary

\begin{tabular}{|c|c|c|}
\hline Parameter & Pre-Retrofit & Post-Retrofit \\
\hline Roof/Ceiling & Uninsulated, vented attic & $\begin{array}{l}\text { Unvented roof assembly: Nominal R-65 } \\
\text { with cellulose in rafter bays and 6-in. } \\
\text { foil-faced polyisocyanurate exterior } \\
\text { sheathing }\end{array}$ \\
\hline $\begin{array}{l}\text { Above-Grade } \\
\text { Walls }\end{array}$ & Uninsulated, wood-framed & $\begin{array}{l}\text { Nominal R-40: Cellulose in wall } \\
\text { framing cavities and 4-in. foil-face } \\
\text { polyisocyanurate }\end{array}$ \\
\hline Windows & $\begin{array}{l}\text { Single-pane, } U=0.87 \text {, } \\
\quad S H G C=0.62\end{array}$ & $\begin{array}{c}\text { Triple-glazed, krypton/argon blend, } \\
\text { low-E vinyl windows; } \mathrm{U}=0.2, \mathrm{SHGC}= \\
0.25\end{array}$ \\
\hline Infiltration & $9.3 \mathrm{ACH} 50$ & $0.7 \mathrm{ACH} 50$ \\
\hline Floor/Foundation & Uninsulated & $\begin{array}{l}\text { R-18 closed-cell high-density spray } \\
\text { foam on basement walls, no slab } \\
\text { insulation }\end{array}$ \\
\hline $\begin{array}{l}\text { Heating and } \\
\text { Cooling }\end{array}$ & $\begin{array}{l}\text { Hydronic heating, oil-fired } \\
\text { boiler, } 73 \% \text { AFUE } \\
\text { No cooling }\end{array}$ & $\begin{array}{c}\text { Forced air, } 96.7 \% \text { AFUE sealed } \\
\text { combustion gas furnace in conditioned } \\
\text { space } \\
\text { 14 SEER air conditioner }\end{array}$ \\
\hline Ventilation & Bathroom exhausts only & $72 \%$ effective HRV \\
\hline DHW & $0.59 \mathrm{EF}$ gas heater, with tank & $\begin{array}{l}\text { 100-gal solar thermal system with } \\
\text { electric backup tanks }\end{array}$ \\
\hline Lighting & $20 \%$ CFLs & $100 \%$ ENERGY STAR CFLs \\
\hline Appliances & Conventional appliances & ENERGY STAR appliances \\
\hline $\begin{array}{c}\text { Site-Generated } \\
\text { Power }\end{array}$ & None & 4.3-kW PV system \\
\hline
\end{tabular}

The seven months of available gas use are shown in Figure 35 and six months of available electricity use are shown in Figure 36. The full year of energy use and generation in Table 5 was estimated by interpolating the data available up to this point. The extremely low gas use compared to other homes (Table 5) is likely to due to careful monitoring as part of THC efforts as well as the fact that the solar thermal hot water system has electric backup and does not use gas. 


\section{Belmont Two Family Natural Gas Use}

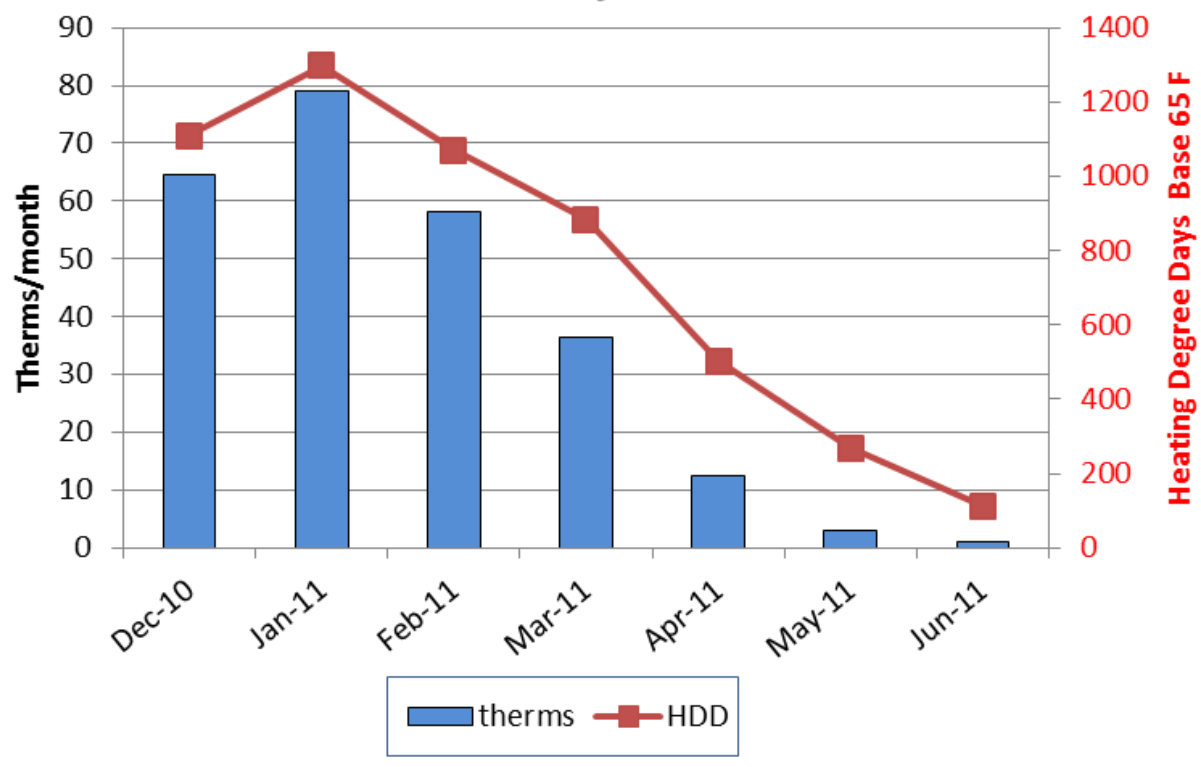

Figure 35. Belmont Two Family post-retrofit gas use

\section{Belmont Two Family Electrical Consumption \& PV Production}

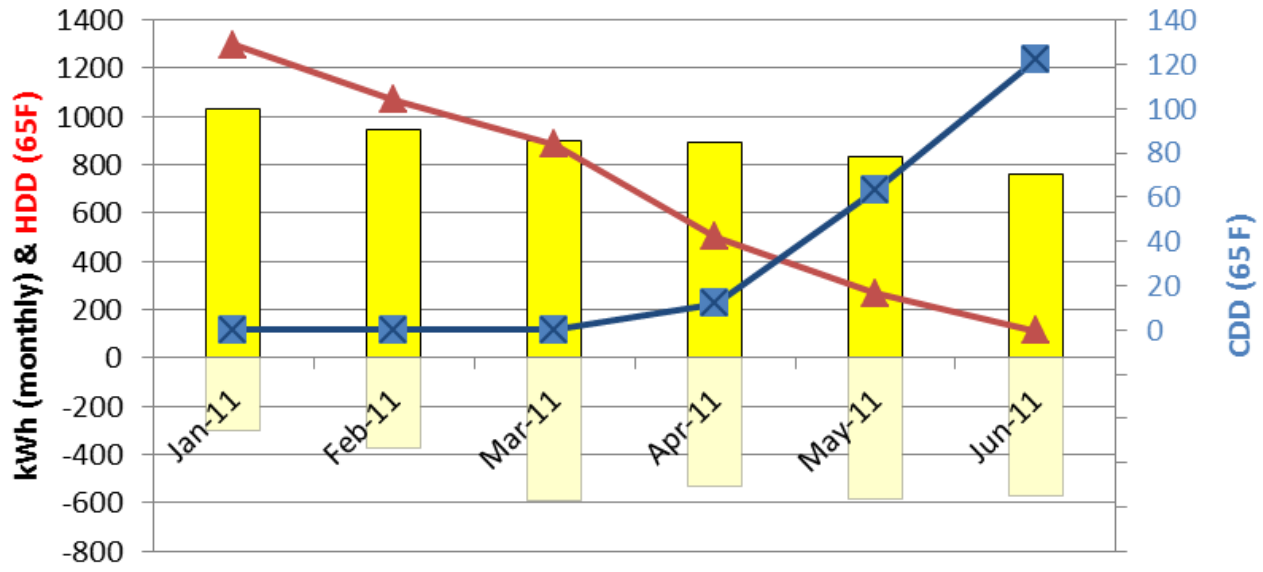

$$
\begin{array}{ll|}
\square \text { Electric Consumption (kWh) } \\
\square \text { PDD } & -\varangle-\mathrm{CDD} \text { Production }(\mathrm{kWh}) \\
\hline
\end{array}
$$

Figure 36. Belmont Two Family post-retrofit electricity use and generation

\subsubsection{Quincy Bungalow}

The following graphs show records of pre-and post-retrofit energy use as well as a predictive parametric energy model for the Quincy Bungalow. The BEopt modeling inputs are shown in Table 12. In the first steps of the parametric analysis (Figure 37), the size of the pre-retrofit, twostory home was increased to three stories while maintaining the other parameters of the original 
home size. The upgrades were then added incrementally to reach the post-retrofit state. In the final state, the effect of the $6.25-\mathrm{kW}$ PV system is shown.

Table 12. Quincy Bungalow Pre- and Post-Retrofit Modeling Summary

\begin{tabular}{|c|c|c|}
\hline Parameter & Pre-Retrofit & Post-Retrofit \\
\hline Roof/Ceiling & $\begin{array}{l}\text { Unvented conditioned attic, } \\
\text { nominal R-30 }\end{array}$ & $\begin{array}{l}\text { Unvented conditioned attic, nominal R- } \\
62,10 \text {-in. open-cell spray foam in rafter } \\
\text { cavities and 4-in. polyisocyanurate } \\
\text { insulating sheathing }\end{array}$ \\
\hline $\begin{array}{l}\text { Above-Grade } \\
\text { Walls }\end{array}$ & Nominal R-12 & $\begin{array}{l}\text { Nominal R-38, open-cell spray foam } \\
\text { insulation in rafter cavities, } 4 \text {-in. } \\
\text { polyisocyanurate insulating sheathing }\end{array}$ \\
\hline Windows & $\mathrm{U}=0.5, \mathrm{SHGC}=0.35$ & $\begin{array}{l}\text { Triple-pane, low-E, krypton blend or } \\
\text { argon gas filled, } \mathrm{U}=0.2, \mathrm{SHGC}=0.23\end{array}$ \\
\hline Infiltration & $18.5 \mathrm{ACH} 50$ & $1.3 \mathrm{ACH} 50$ \\
\hline Floor/Foundation & $\begin{array}{l}\text { Uninsulated basement and } \\
\text { crawlspace }\end{array}$ & R-24 basement walls, R-10 crawlspace \\
\hline $\begin{array}{l}\text { Heating and } \\
\text { Cooling }\end{array}$ & $\begin{array}{l}\text { 85\% AFUE, oil-fired, ducts in } \\
\text { conditioned space } \\
\text { No cooling }\end{array}$ & $\begin{array}{c}\text { Heat pump and direct-fired storage } \\
\text { water heater with heat exchanger for } \\
\text { heating and input from solar thermal } \\
\text { system modeled as } 90 \% \text { AFUE gas-fired } \\
\text { furnace }\end{array}$ \\
\hline Ventilation & No mechanical ventilation & $\begin{array}{c}\text { Balanced ventilation with } 88 \% \text { efficient } \\
\text { HRV }\end{array}$ \\
\hline DHW & 0.62 EF oil-fired boiler & $\begin{array}{l}6 \text { solar DHW panels integrated with } \\
\text { direct-fired storage water heater }\end{array}$ \\
\hline Lighting & $40 \%$ CFLs & $40 \%$ CFLs \\
\hline Appliances & ENERGY STAR appliances & ENERGY STAR appliances \\
\hline $\begin{array}{l}\text { Site-Generated } \\
\text { Power }\end{array}$ & None & 6.25-kW PV array \\
\hline
\end{tabular}




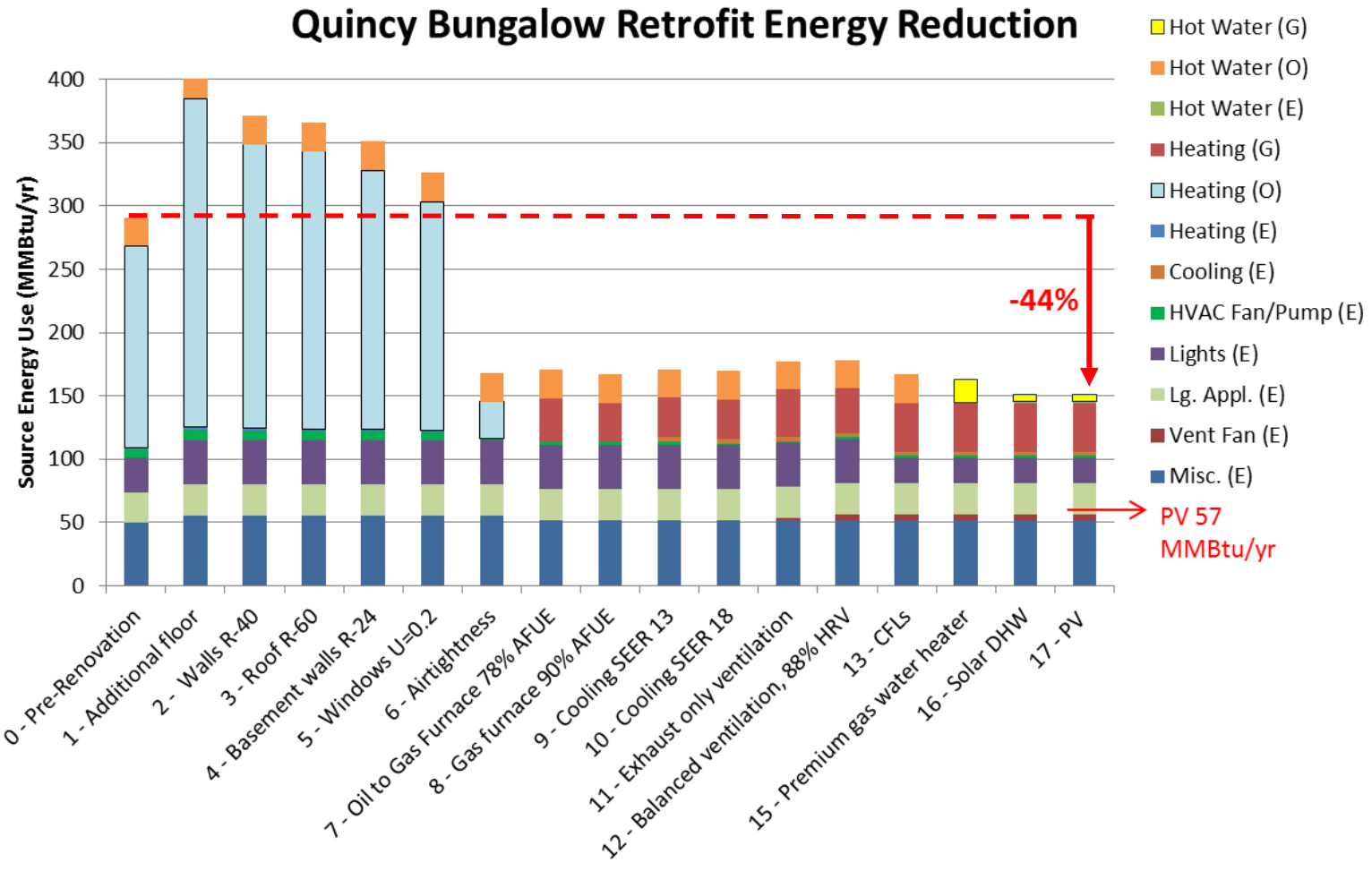

Figure 37. Parametric energy modeling analysis of the Quincy Bungalow

As the owners had lived in the home for a number of years prior to the retrofit, National Grid was able to provide several years of pre-retrofit electricity use (Figure 38). However, good records of the amount of oil used each year for pre-retrofit heating did not exist, so a pre-retrofit BEopt energy model was used to estimate the oil use.

As the retrofit was completed in December 2010, seven months of post-retrofit utility data were available at the time of this writing. Post-retrofit gas use (after the switch from oil heating) is plotted in Figure 39. A record of pre-retrofit oil use was not available, so was estimated using the energy model. Full year post-retrofit energy use was estimated by extrapolating the missing months from these data.

The BEopt energy model in Figure 37 predicts a source energy reduction of $44 \%$. As shown in Table 5, a $41 \%$ reduction is calculated when real pre- and post-retrofit data are included where available. When a full year of PV generation is also extrapolated from the available six months, the source energy reduction increases to $66 \%$. It should be noted that although January energy use was included, some solar thermal and other move-in adjustments were still being made.

These calculated energy reductions should be verified after at least a full year of post-retrofit energy data is available. However, the ballpark reductions predicted are impressive when one considers the fact that an additional above-grade floor was added during the DER. 
Quincy Bungalow Electrical Consumption \& PV Production

Renovation period; moved back in Dec 2010

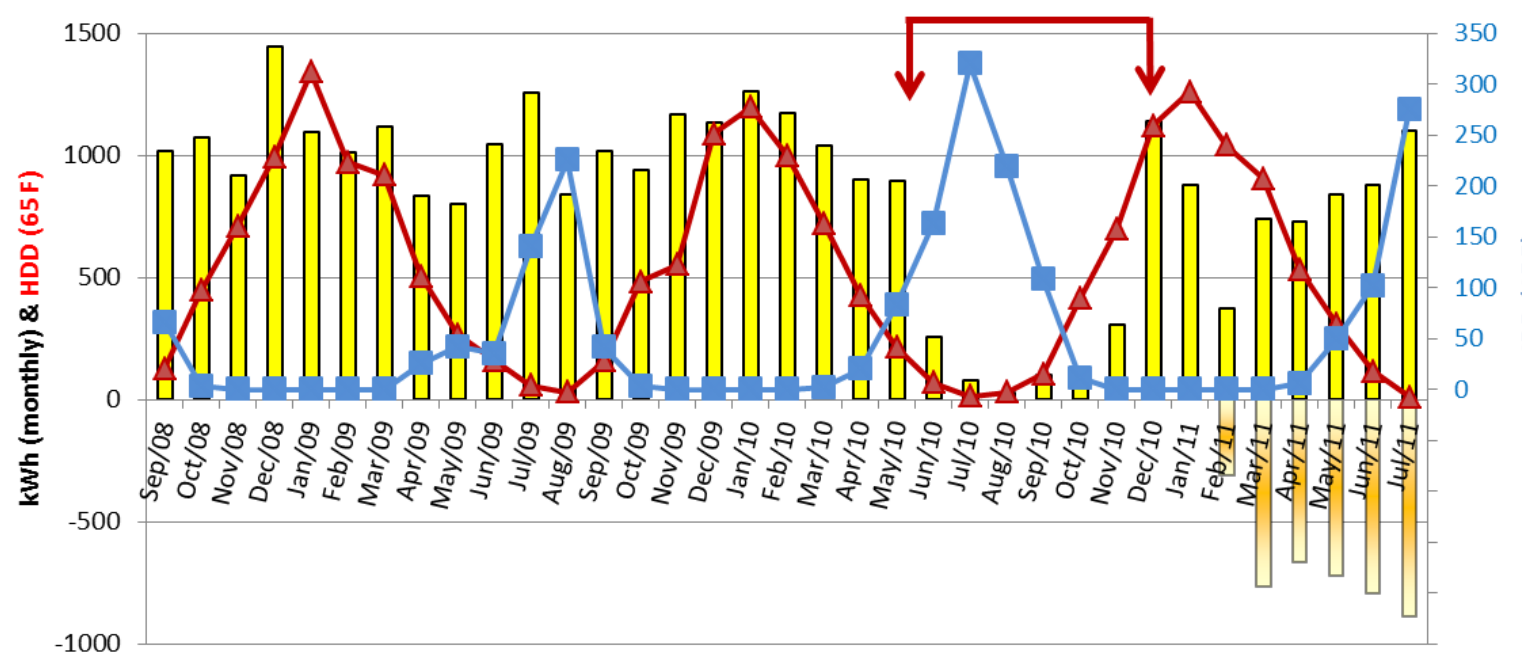

$\hookrightarrow$ Power used in home $\rightleftarrows$ kWh Produced $\longrightarrow$ HDD $\rightarrow-C D D$

Figure 38. Graph of electricity use and PV generation of the Quincy Bungalow Quincy Bungalow Gas Consuption

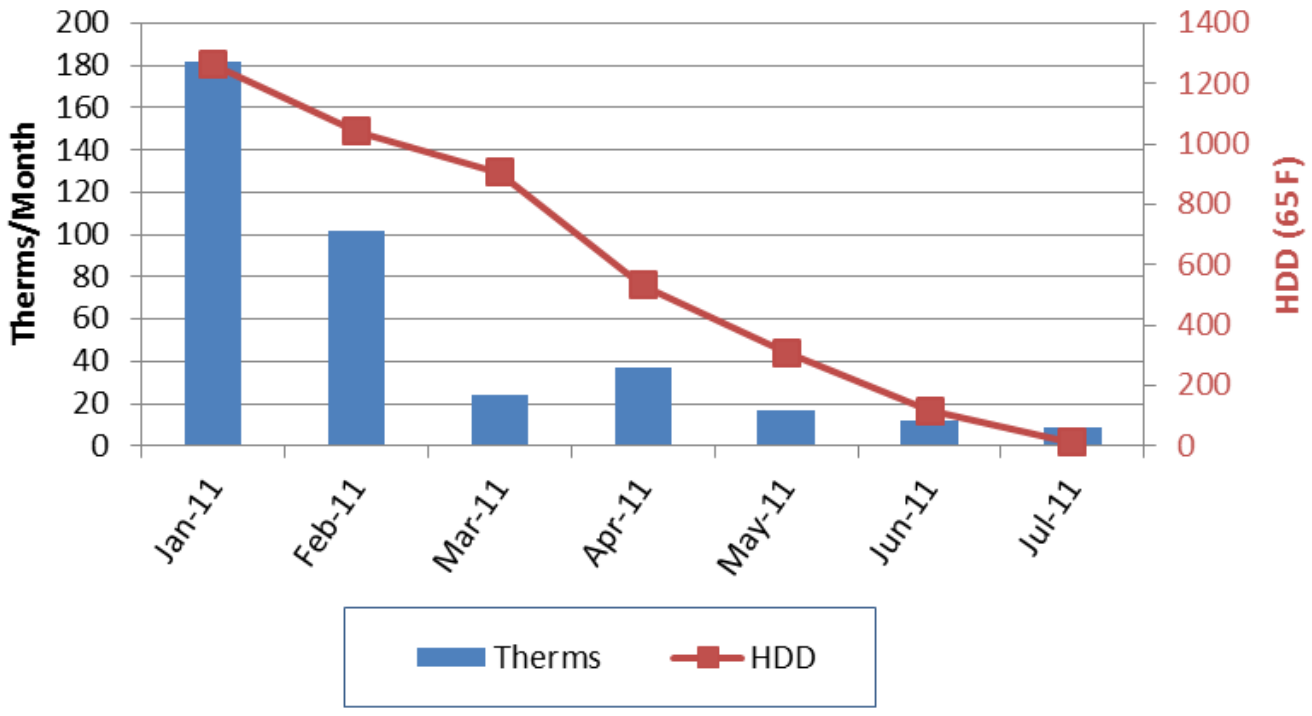

Figure 39. Graph of natural gas use following the Quincy Bungalow DER 


\subsubsection{Millbury Cape}

During the course of the Millbury Cape retrofit, a heating system switch from oil to the electric heat pump occurred. Both before and after the retrofit, wood pellets were used for supplemental space heating. For water heating, a high efficiency instantaneous propane-fired water heater was installed; DHW was previously provided by the oil boiler. The mixture of fuels used before and after the retrofit is taken into account in the calculations in Table 5. The BEopt modeling inputs are shown in Table 13. The parametric energy graph below (Figure 40) was generated by the BEopt model for the Millbury Cape showing incremental inclusion of the retrofit measures. Energy modeling was not used during project planning. However, as the project neared completion, BEopt was introduced as an analysis tool for understanding the expected and observed energy use. This model projects an average yearly $45 \%$ reduction in source energy use following the retrofit. BEopt was not able to capture the use of the wood pellet stove that was used for heating and will continue to be used occasionally in the post-retrofit state. As shown in Table 5, an actual source energy reduction of $23 \%$ is calculated using the pre- and post- retrofit data available.

Table 13. Millbury Cape Pre- and Post-Retrofit Modeling Summary

\begin{tabular}{|c|c|c|}
\hline Parameter & Pre-Retrofit & Post-Retrofit \\
\hline Roof/Ceiling & Vented attic, R-30 attic floor & $\begin{array}{l}\text { Unvented roof assembly, nominal R- } \\
\text { 56, 5-in. spray foam in roof rafters and } \\
\text { 4-in. foil-faced polyisocyanurate } \\
\text { insulating sheathing }\end{array}$ \\
\hline $\begin{array}{l}\text { Above-Grade } \\
\text { Walls }\end{array}$ & $\mathrm{R}-15$ batts in wood framing & $\begin{array}{c}\text { Nominal R-41, R-15 batts in framing } \\
\text { cavities and } 4=- \text { in. foil-faced } \\
\text { polyisocyanurate }\end{array}$ \\
\hline Windows & $\begin{array}{l}\text { Double-glazed, } \mathrm{U}=0.45, \\
\quad \mathrm{SHGC}=0.55\end{array}$ & $\begin{array}{l}\text { Triple-glazed, argon-filled, vinyl frame, } \\
\qquad \mathrm{U}=0.25, \mathrm{SHGC}=0.25\end{array}$ \\
\hline Infiltration & $10.4 \mathrm{ACH} 50$ & 1.4 ACH 50 \\
\hline Floor/Foundation & Uninsulated & $\begin{array}{l}\text { R-20 basement walls: } 3 \text {-in. rigid } \\
\text { polyisocyanurate }\end{array}$ \\
\hline $\begin{array}{l}\text { Heating and } \\
\text { Cooling }\end{array}$ & $\begin{array}{c}60 \% \text { AFUE oil-fired boiler, hydronic } \\
\text { Window air conditioners, } \\
10 \text { SEER }\end{array}$ & $\begin{array}{l}\text { 14 SEER, 8.6 HSPF heat pump } \\
\text { Pellet stove for supplementary heating } \\
\text { could not be modeled in BEopt }\end{array}$ \\
\hline Ventilation & Bathroom exhausts & $\begin{array}{l}\text { Supply-only mechanical ventilation, } \\
\text { spot-exhausts in bathrooms }\end{array}$ \\
\hline DHW & $\begin{array}{c}\text { Modeled as } 0.62 \text { EF oil-fired water } \\
\text { heater }\end{array}$ & $\begin{array}{c}0.82 \mathrm{EF} \text { propane on-demand water } \\
\text { heater }\end{array}$ \\
\hline Lighting & $20 \%$ CFLs & $100 \%$ ENERGY STAR CFLs \\
\hline Appliances & Conventional appliances & $\begin{array}{l}\text { ENERGY STAR appliances (included } \\
\text { in model) }\end{array}$ \\
\hline $\begin{array}{l}\text { Site-Generated } \\
\text { Power }\end{array}$ & None & None \\
\hline
\end{tabular}




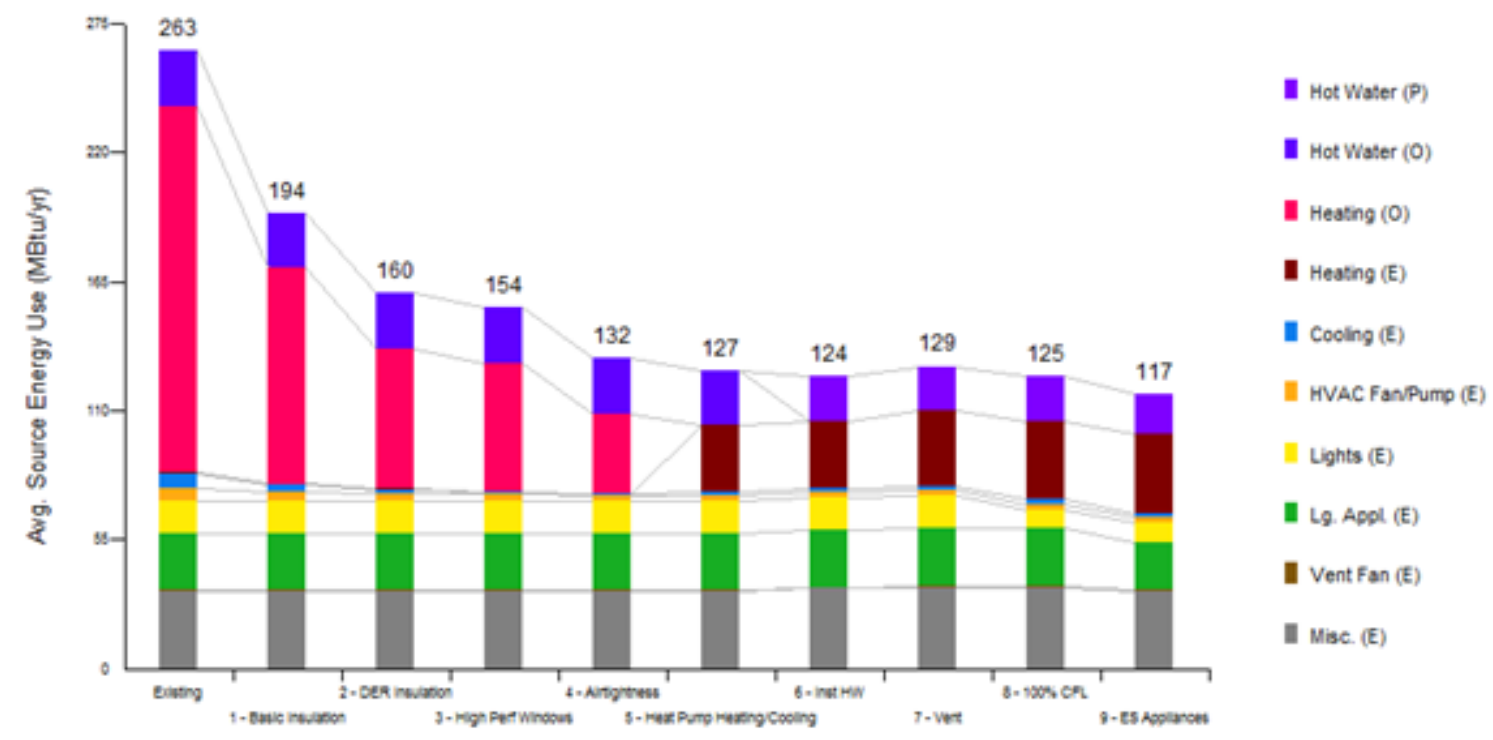

Figure 40. BEopt incremental modeling results for the Millbury Cape

Available electricity use from before and after the retrofit is graphed in Figure 41. Monthly incremental use data of delivered fuels (pellets, oil, and propane) were not available; only total use data were available for the calculations in Table 5. Because of the switch from oil to air source heat pump heating, electricity use actually increased after the retrofit from 7,570 to $11,058 \mathrm{kWh} / \mathrm{yr}$.

\section{Millbury Cape Electricity Consumption}

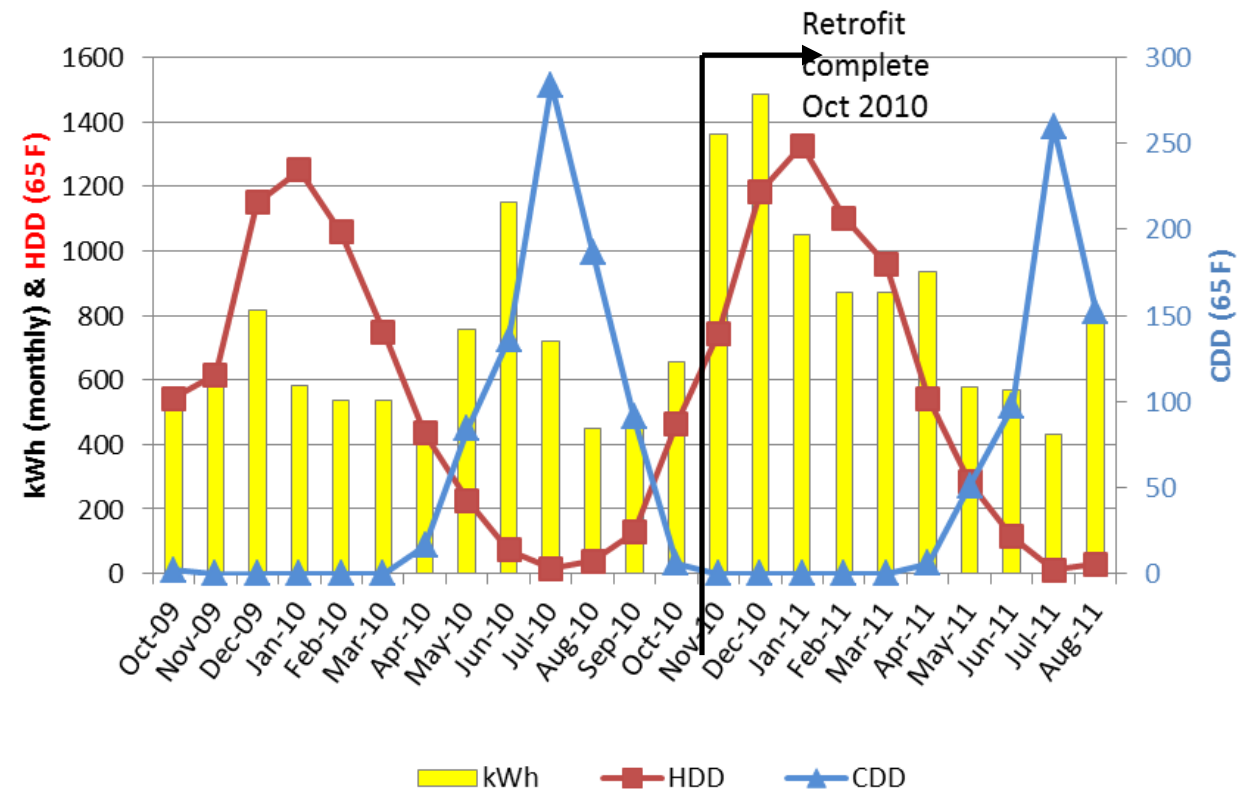

Figure 41. Pre- and post-retrofit monthly electricity use for the Millbury Cape 


\subsection{Weather and Energy Savings: ASHRAE Guideline 14-2002 and the Inverse Modeling Toolkit}

As noted in the presentation of Table 5, limited data were available for the pre- and post-retrofit homes. Some homes lacked pre-retrofit utility bills or a complete year of post-retrofit bills. To make up for these deficiencies, data needed to be interpolated, and bill data compared to model data. Pre- and post-retrofit occupancy, temperature set points, and internal loads often differed. Furthermore, the homes experienced different weather conditions during the available energy use periods. Although weather conditions differ among homes in this study, they also vary from preto post-retrofit for individual homes. These factors were sources of variation and error in attempts to judge each home's energy savings, or to compare and rank their energy use. Uncertainties in comparative home energy savings are seen as one obstacle to widespread adoption of these retrofit methods.

The American Society of Heating, Refrigerating and Air-Conditioning Engineers (ASHRAE) Guideline 14-2002 (ASHRAE 2002) addresses these issues and proposes methodology for obtaining meaningful retrofit savings. However, it was discovered that in order to successfully implement 14-2002 methodology, substantially more information than can be readily obtained is needed.

Guideline 14-2002 proposes three methodologies for determination of retrofit energy savings. They are summarized below:

- Whole-Building Energy Approach. When pre- and post-retrofit utility data are available by month, pre-retrofit data are calibrated to post-retrofit data as if they experienced the same weather conditions or other variables (such as occupancy).

- Retrofit Isolation Approach. This method is used for determining savings from individual retrofit upgrades through the use of detailed submetering of energy end uses.

- Calibrated Simulation Approach. This method is used to determine energy savings when pre- or post-retrofit utility data are unavailable. For example, if only post-retrofit utility data are available, an energy model is created to represent the post-retrofit home, using utility bills and real weather data from that time period to calibrate the model. This model is then adjusted to represent the pre-retrofit case and run using the post-retrofit weather data.

The first and third methodologies were examined to determine if they could be used to calculate more accurate energy savings.

\subsubsection{Whole-Building Energy Approach: Somerville Triple Decker}

The whole-building energy approach is implemented through the use of software called the Inverse Modeling Toolkit (IMT) (Kissock et al. 2002). This software can be used to develop mathematical relationships between energy use (the dependent variable) and external factors such as outdoor air temperature (the independent variable). Once an equation for this relationship is generated, different weather data can be plugged in so that pre- and post-retrofit periods can be compared as if they experienced the same weather. 
The possible approaches offered in the IMT require different amounts of data. For the retrofits discussed in this report, the most detailed energy use data available are electricity use by month and gas use by month; no hourly or daily data are available. However, only one of the homes, the Somerville Triple Decker, had a full year of both pre- and post-retrofit monthly electricity and gas use data. Tabulations of fuels delivered at irregular intervals such as oil, pellets, and wood could not be analyzed in this way as their actual uses in the home were not measured by month. Discrete quantities of fuel could not be lined up with outdoor temperature to generate a correlation.

The Somerville Triple Decker's complete set of monthly electricity and gas data allowed the use of the Variable-Base Heating and Cooling Degree-Day Model (Kissock et al. 2002). This model is used to generate a linear relationship between degree days and energy use. HDDs may be correlated to gas use and CDDs to electricity use. More complex models capable of developing nonlinear, multivariate relationships require daily or hourly energy use, preferably divided out by end use (such as hourly energy use used by a boiler for a year). Typical homes do not submeter these data unless a special study is being performed; it is not required by the National Grid DER program.

Data from the Somerville Triple Decker were run through the IMT/14-2002 methodology in order to get an idea of the effect of weather data normalization as a technique that might be used in future retrofit studies with more data available.

An equation for the relationship between degree days and energy use is generated from preretrofit data. These are then used to perform a fair comparison of pre- and post-retrofit energy use as if the same weather had occurred in both scenarios. The effort is summarized in the following steps:

1. A text file containing a column of pre-retrofit daily average temperature lined up with a column of monthly energy use is created. Monthly energy use is entered for the last day of each billing period; null values are entered in the remainder of each month.

2. The IMT software reads this file and calculates the ideal heating or CDD base temperature ${ }^{1}$ and a linear regression equation of the form

Energy Use per Month $=[\mathrm{X} 1 \times$ Degree Days@ calculated base T $]+\mathrm{A}$

along with the values of $\mathrm{X} 1, \mathrm{~A}$, and $\mathrm{R}^{2}$ (coefficient of determination) for the regression line. The value of $\mathrm{X} 1$ represents the slope of the line on an energy use/degree day graph. The value of $\mathrm{A}$ is the intercept on the energy use axis; this is also an estimate for the base load.

3. The yearly post-retrofit degree days at the calculated pre-retrofit base temperature are then plugged into the equation above to get the weather-adjusted pre-retrofit energy use.

\footnotetext{
${ }^{1}$ Elsewhere in this report, base $65^{\circ} \mathrm{F}$ degree days have been graphed and tabulated as representations of weather conditions for each home, but have not been used to scale or adjust tabulated energy use. Calculation of the "ideal" base temperature is necessary for any energy use adjustment as specified by ASHRAE 14-2002 and IMT methodology.
} 
Because the equation represents monthly energy use, if yearly degree days are used, the value of ' $A$ ' should be multiplied by 12 to calculate yearly energy. This is an estimate of the amount of energy the pre-retrofit home would have used if it had experienced identical weather to the post-retrofit home. This quantity is then compared to the actual post-retrofit energy use to compute savings.

The IMT's Variable-Base Heating and Cooling Degree-Day Model was applied to the preretrofit Somerville Triple Decker data for both heating (gas) and cooling (electricity). The year from April 2009 to March 2010 was used as the pre-retrofit period and November 2010 to October 2011 as the post-retrofit period. These represent the earliest and latest data available; the goal was to leave out the period of time when the retrofit was partially complete. The same occupants who lived in the pre-retrofit house continue to live in the post-retrofit house, reducing one source of error in the comparison. Because the building contains three apartments, three sets of utility bills had to be aggregated. The bills were usually dated for the $21^{\text {st }}$ of each month, the last day of the billing period. Sometimes one apartment's billing period would fall a couple of days later or earlier. In order to obtain the monthly energy use datasets, energy use from all three apartments was added together and formatted so that each month's energy use was reported on the $21^{\text {st }}$.

As expected, the correlation of CDDs to electricity use is poor $\left(\mathrm{R}^{2}=0.15\right)$; the correlation of HDDs to gas use is excellent $\left(\mathrm{R}^{2}=0.95\right)$. Air conditioning in hot weather is likely to represent a relatively small amount of total energy use for the Somerville Triple Decker; occupants reported using their window air conditioners sparingly. Previous BA work has found that the lessdominant load for a region (e.g., cooling loads in a heating-dominated climate such as New England) has poor correlation between monthly energy use and degree days (BSC 2008). Many factors influencing miscellaneous electricity use are unrelated to weather. The pre-retrofit Somerville Triple Decker's forced hot air system also used electricity for fans in addition to gas for the furnace, throwing off the attempt to correlate cold days with lower energy use.

Because of the poor correlation of electricity use to CDDs, the remainder of the weather correlation adjustment procedure was abandoned. However, the corresponding exercise for gas use was completed. Figure 42 shows the graph of pre-retrofit gas use versus HDDs at the calculated base temperature and the linear regression equation calculated by the IMT. The results for the weather normalization effort are shown in Table 14. 


\section{Pre-Retrofit Gas Use vs. Degree Days}

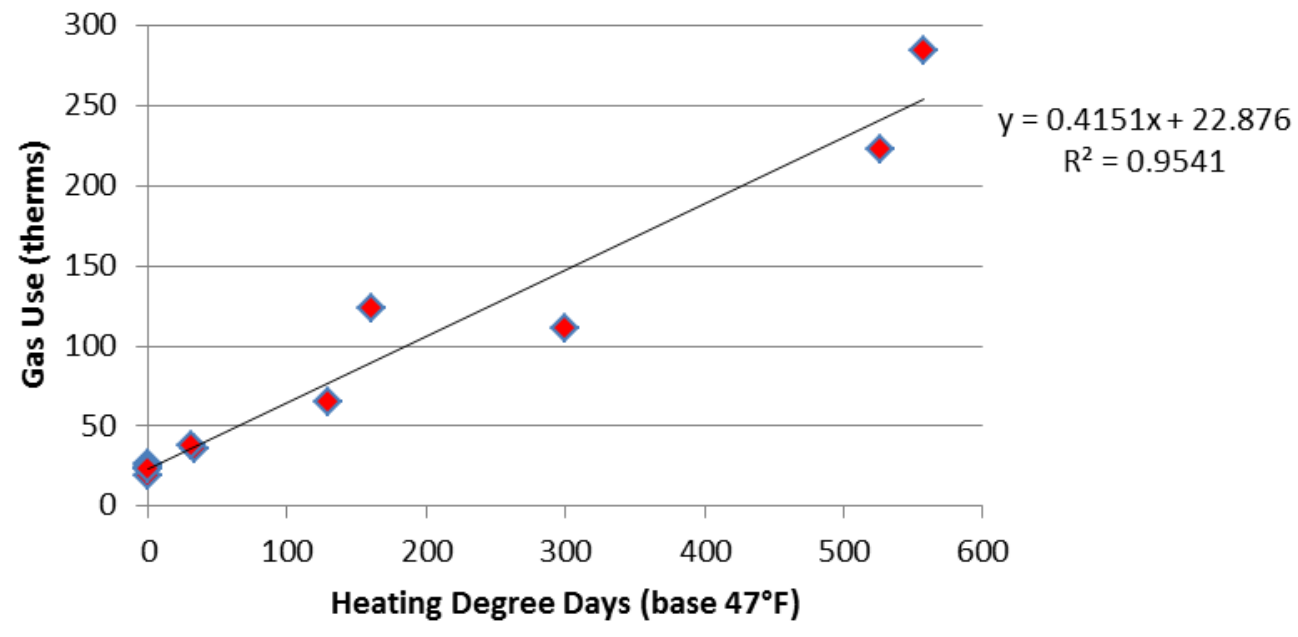

Figure 42. Pre-retrofit gas use versus base $47^{\circ} \mathrm{F}$ HDDs

Table 14. Somerville Triple Decker Weather Calibration Results: Gas and HDDs

\begin{tabular}{|c|c|c|c|}
\hline & $\begin{array}{c}\text { Pre-Retrofit } \\
\text { April } 2009 \text { to March } \\
2010\end{array}$ & $\begin{array}{l}\text { Post-Retrofit } \\
\text { November } 2010 \text { to } \\
\text { October } 2011\end{array}$ & $\begin{array}{c}\% \\
\text { Difference }\end{array}$ \\
\hline Linear Regression Correlation & $\mathrm{R}^{2}=0.95$ & $\mathrm{R}^{2}=0.99$ & \\
\hline HDD Base Temperature & $47^{\circ} \mathrm{F}$ & $60^{\circ} \mathrm{F}$ & \\
\hline X1 (slope) & 0.4151 & 0.0817 & \\
\hline A (base load) & 22.9 therms & 14.8 therms & \\
\hline HDDs (base $47^{\circ} \mathrm{F}$ ) & 1738 (base $47^{\circ} \mathrm{F}$ ) & $\begin{array}{l}2017\left(\text { base } 47^{\circ} \mathrm{F}\right)^{2} \\
4416\left(\text { base } 60^{\circ} \mathrm{F}\right)\end{array}$ & $14 \%$ \\
\hline Actual Energy Use (from bills) & 996 therms & 538 therms & $46 \%$ \\
\hline $\begin{array}{c}\text { Weather-Normalized Energy } \\
\text { Use }\end{array}$ & 1112 therms & Use value above & $52 \%$ \\
\hline $\begin{array}{l}\text { Difference in Energy Savings as } \\
\text { a Result of This Methodology }\end{array}$ & & & $6 \%$ \\
\hline
\end{tabular}

As shown in Table 14, the weather normalization of the pre-retrofit data resulted in yearly gas savings of $52 \%$ compared to the $46 \%$ that would have been calculated simply by comparing energy use from utility bills before and after the retrofit. The recorded pre-retrofit gas use, 996 therms, increased by $10 \%$ to 1112 therms after the weather adjustment was made. This $10 \%$

\footnotetext{
${ }^{2}$ The post-retrofit degree days at the pre-retrofit base temperature $\left(47^{\circ} \mathrm{F}\right)$ are used for the pre-retrofit energy adjustment calculation. The number of degree days at the post-retrofit base temperature $\left(60^{\circ} \mathrm{F}\right)$ are included to illustrate how much the base temperature affects the number of degree days and therefore the amount of heating the home would be expected to need.
} 
increase corresponds to a $14 \%$ increase in the number of base 47 degree days in the post-retrofit period.

Published base 65 degree days are sometimes used for simplified energy scaling calculations without going through the steps to calculate an ideal base temperature. To normalize pre-retrofit energy to post-retrofit weather, one might scale by the percent difference in base 65 degree days. For this example, it was found that the difference between using base 65 and base 47 produces substantially different results. Although there are 14\% more base 47 HDDs in the post-retrofit period (Table 14Table 14), there are only 4\% more base 65 degree days. This shows the importance of base temperature when degree days are used for energy scaling. If a larger sample of homes were available, the difference between the ASHRAE methodology and a simple scaling based on published base 65 degree days could be examined.

In addition to an adjusted energy savings, other IMT output is of interest. Although it was not necessary to run the post-retrofit data through the IMT software to arrive at the weathernormalized energy savings, this was done in order to compare the regression correlation $\left(\mathrm{R}^{2}\right)$ slope (X1), the base load (A), and the HDD base temperature to those of the pre-retrofit. The $\mathrm{R}^{2}$ value is slightly higher for the post-retrofit period, which makes sense as the improved insulation was likely to even out temperature swings and corresponding heating needs. The post-retrofit slope is also smaller, meaning that for every additional HDD the amount of post-retrofit heating energy is less than the amount of pre-retrofit heating energy. The base loads, representing the amount of gas used per month when no heating is needed (water heating and cooking only), increased by $35 \%$ from pre- to post-retrofit. It is believed that occupancy stayed the same but perhaps more cooking was done.

The HDD base temperatures are of particular interest. All other things being equal, one would expect the base temperature (above which no heating energy is used) to be lower after the retrofit. Insulation, air sealing, and other upgrades should reduce the need for heating and thus lower the temperature above which heating energy is needed. However, in this case the HDD base temperature is calculated as $47^{\circ} \mathrm{F}$ pre-retrofit and $60^{\circ} \mathrm{F}$ post-retrofit. The owner of the Somerville Triple Decker stated that occupants used the pre-retrofit forced-air heating system sparingly as they found it unpleasantly "drying." It was thought that the higher base temperature might be an instance of "take-back," wherein the occupants used the new, more energy-efficient hydronic system to bring their apartments to higher, more comfortable temperatures.

After the analysis was complete, the homeowner was consulted about the pre- and post-retrofit base temperatures. She reported that although the pre-retrofit heating was used sparingly, heating temperatures were kept in the low $60 \mathrm{~s}$, not the low 50s, as might be expected with a base temperature of 47 . The IMT selected this base temperature as the one with the highest $\mathrm{R}^{2}$ value, but it is possible that other base temperatures result in values that are still high enough to indicate a reasonable correlation.

Degree day-based weather normalization of energy consumption has several important sources of inaccuracy, even after an "ideal" base temperature for a building is calculated as in the example above. These include minimal or zero heating use when outdoor air temperatures are relatively near the base temperature and the fact that buildings are heated to different temperatures depending on time of day and occupancy (BizEE 2012). A month of unusual 
occupancy, such as if residents leave during winter holidays, could throw off results. When aggregating monthly data, factors such as the number of weekends in a particular month, when energy use patterns differ, can introduce other sources of error. The Somerville Triple Decker's three apartments add another degree of complexity. Indoor set point temperature preferences and use patterns vary among the occupants. As described above, billing periods varied among the apartments but were aggregated for the $21^{\text {st }}$ of each month, which could have contributed to additional inaccuracies.

Furthermore, heating energy use was adjusted based only on outdoor air dry bulb temperature when many other factors can affect energy use. It was not possible to adjust electricity consumption because of its poor correlation to the only reasonable and readily available daily parameter (outdoor air temperature); submetered electricity use data for air conditioning or other miscellaneous uses were unavailable. This simplified and incomplete procedure was as far as the exercise could go with the data available, yielding highly questionable results. However, it is hoped that the effort provides insights into factors that should be considered when quantifying a retrofit's energy use reduction. Analysis results from low-resolution monthly data should not be taken at face value because of the sources of error discussed.

\subsubsection{Calibrated Simulation Approach}

Three homes discussed in this report (the Concord Foursquare, the Bedford Farmhouse, and the Belmont Two Family) had no pre-retrofit utility bills available, as the present occupants did not live in the homes until the retrofits were complete. However, post-retrofit utility bills were available. These would have been excellent candidates for the Calibrated Simulation Approach, creating calibrated pre-retrofit models from models calibrated to post-retrofit consumption (ASHRAE 2002). The models would both need to use a weather file representing the postretrofit period, covering a year during 2010 and 2011. Recent hourly wet and dry bulb temperature data are available for free, but the required hourly solar radiation parameters are quite expensive (such as \$2000 per year of data from the company Clean Power Research). Most hourly energy models use free typical meteorological year data, meant to represent average weather conditions over a long period of time, and not weather data for a particular year. In addition to this data cost, the creation of energy models calibrated to the level of monthly precision specified by ASHRAE 14-2002 is quite time consuming and would generally be beyond the budget for residential projects. Although the inaccuracies of comparing pre-retrofit model data to post-retrofit bill data are likely to be significant, a method of adjusting for these factors within typical project budgets is needed.

ASHRAE Guideline 14-2002 and the IMT offer fair and scientific methodologies to account for varying weather conditions and incomplete datasets to achieve more accurate calculation of energy savings. Unfortunately, the efforts described above illustrate the difficulty of fully applying the methodology due to typical data and budget limitations. Of the seven retrofit projects discussed in this report, it was only possible to follow the ASHRAE Guideline for the heating fuel use of a single house.

These methodologies are likely more applicable to large commercial building retrofits where significant energy savings and monetary incentives are at stake, and more detailed energy end use data are available. These tools should be applied in residential projects when allowed by the 
budget and available dataset; however, guidelines for less precise but more practical methodology would be useful additions to the field.

\subsection{Homeowner Satisfaction}

An effort was made to collect feedback from all seven of the homeowners. Written feedback and survey results from occupants who actually live in the homes studied can provide valuable insights that may be indecipherable from sources such as utility bills and models. Homeowner satisfaction with these retrofits is extremely important, considering the substantial investments that the homeowners have made in these projects. Evidence of their satisfaction is also critical in the effort to increase the popularity and number of similar efforts in the United States. Homeowners and builders may perceive risk in DER strategies simply because they have not yet been widely implemented; homeowner feedback from successful retrofits helps to encourage widespread adoption.

The owners of both the Belmont Two Family and Somerville Triple Decker have aided in this effort by making many of their retrofit details and processes public by documenting their experiences in Internet blogs. These serve to increase visibility and awareness of the benefits and processes of DER strategies.

Various forms of positive feedback were received from occupants through emails and in-person conversations. Several of the homeowners remarked on the evenness of comfort and temperatures maintained in their homes, and the speed and ease with which temperatures could be adjusted using control systems.

In addition to positive comments about thermal comfort, the owners of the Millbury Cape and Somerville Triple Decker, who had both lived in their homes prior to the retrofit, noted the lack of ice dams following the roof insulation and air sealing (Figure 43). Ice dams typically occur when conductive heat or warm air escaping the roof melts snow, which then refreezes after running down to the edge of the roof (Lstiburek 2011). Ice dams often lead to water leakage into building assemblies. Worse, when an ice dam gets too heavy it can snap off, sometimes taking a piece of roof with it. Ice dams can be prevented by keeping the roof surface as cold as possible. With a vented roof, this is done by insulating and air sealing the attic floor well and ensuring outside air ventilation under the roof. For the Millbury Cape, $2 \times 4 \mathrm{~s}$ on the flat were inserted between the insulating sheathing and the outer layer of plywood, creating a vented roof capped by a ridge vent. In this case, the $2 \times 4 \mathrm{~s}$ were attached to the existing roof rafters and the plywood sheathing was attached to the $2 \times 4$ s. This created a "vented over-roof," successfully keeping the roof cold while still creating an attic space within the thermal enclosure. 


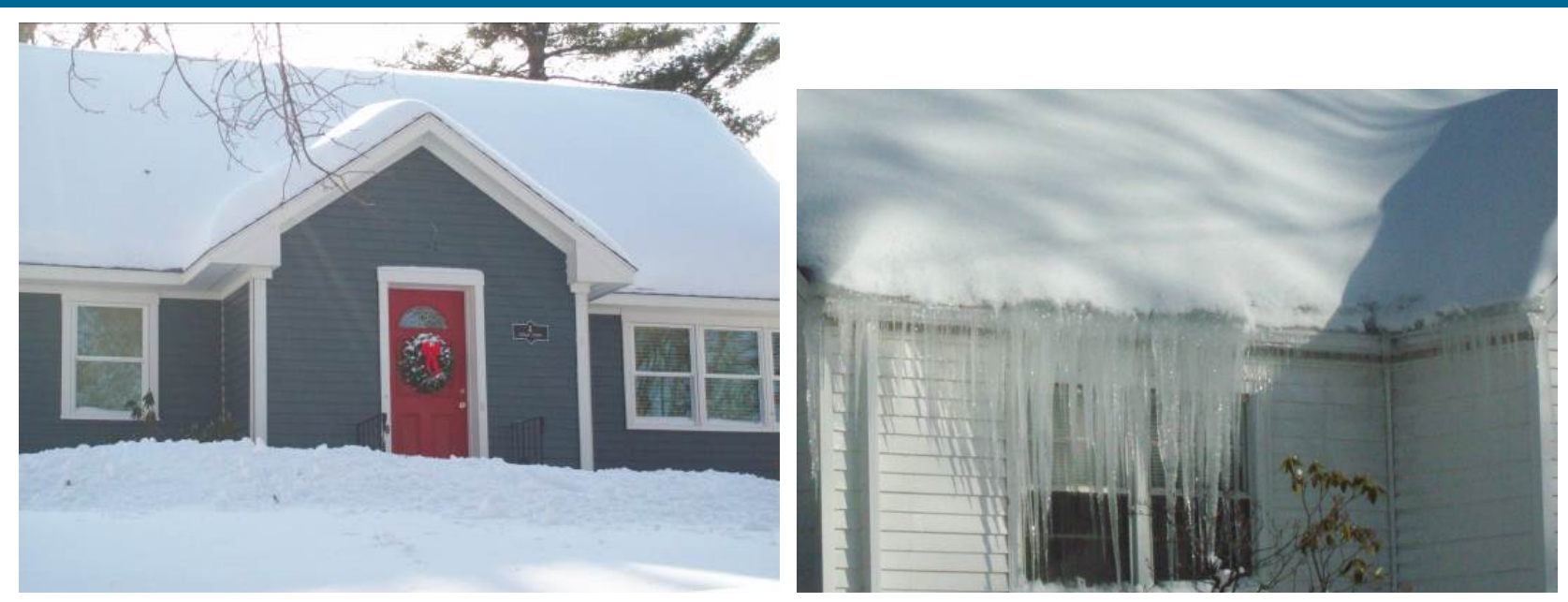

Figure 43. Left: Post-retrofit Millbury Cape; Right: Neighbor's home with ice dams

An occupant survey was designed for and distributed to the occupants of all of the homes. This survey is a modified version of the sample provided by Norton et al. (2008). In addition to helping gauge occupant perceptions and satisfaction, responses to questions about home appliances were meant to pinpoint any potential causes for high miscellaneous loads were these to be observed in the future. A copy of the homeowner survey is included in Appendix A.

The last page of the survey was meant to gauge occupant satisfaction with the retrofit. Occupants were asked to respond to questions on a scale of 1 to 5, marked as "Strongly Disagree," "Disagree," "Neutral/Unsure," "Agree," and "Strongly Agree," respectively. Questions in the present tense refer to the current, post-retrofit state of the homes.

The owners of the Concord Foursquare, the Belmont Two Family, the Millbury Cape, the Somerville Triple Decker, and the Belchertown Cape all responded to the questionnaire. The first letters of the towns where the homes are located will be used to designate responses in Table 15 .

Table 15 shows responses regarding occupant comfort and satisfaction. Both the Belchertown Cape and the Belmont Two Family start with the letter B, so these will be referred to as B1 and $\mathrm{B} 2$ respectively.

Pre-retrofit-related responses of the Concord Foursquare and the Belmont Two Family homeowners are absent because they did not live in the pre-retrofit homes. 
Table 15. DER Homeowner Survey Responses

\begin{tabular}{|c|c|c|c|c|c}
\hline Question & $\begin{array}{c}\text { Strongly } \\
\text { Disagree }\end{array}$ & Disagree & $\begin{array}{c}\text { Neutral/ } \\
\text { Unsure }\end{array}$ & Agree & $\begin{array}{c}\text { Strongly } \\
\text { Agree }\end{array}$ \\
\hline $\begin{array}{c}\text { My home was comfortable in } \\
\text { winter before the retrofit. }\end{array}$ & B1 & M & S & & \\
\hline $\begin{array}{c}\text { My home is comfortable in } \\
\text { winter (after the retrofit). }\end{array}$ & & & & & S,B1,M,C,B2 \\
\hline $\begin{array}{c}\text { My home was comfortable on } \\
\text { warm/hot days before the } \\
\text { retrofit. }\end{array}$ & B1 & S,M & & & \\
\hline $\begin{array}{c}\text { My home is comfortable on } \\
\text { warm/hot days (after the } \\
\text { retrofit). }\end{array}$ & & & & S,B1,M,C,B2 \\
\hline $\begin{array}{c}\text { My home sometimes feels } \\
\text { "stuffy." }\end{array}$ & B1,C & S,B2 & & winter") & \\
\hline $\begin{array}{c}\text { All the rooms in my house are } \\
\text { equally comfortable. }\end{array}$ & & & & & S,B1,M,C,B2 \\
\hline $\begin{array}{c}\text { I am satisfied with the overall } \\
\text { comfort of my home. }\end{array}$ & & & & S,B1,M,C,B2 \\
\hline $\begin{array}{c}\text { My home has low utility bills } \\
\text { for its size. }\end{array}$ & & & & M & S,B1,C,B2 \\
\hline $\begin{array}{c}\text { The HVAC control systems in } \\
\text { my home are easy to operate. }\end{array}$ & & & & & S,B, M, B,B2 \\
\hline $\begin{array}{c}\text { I am satisfied with my home } \\
\text { overall. }\end{array}$ & & & & & C,B1,M,C,B2 \\
\hline $\begin{array}{c}\text { The low energy features of } \\
\text { my home are important to } \\
\text { me. }\end{array}$ & & & & & \\
\hline
\end{tabular}

Results indicate high overall satisfaction among homeowners who completed the survey and a marked increase in comfort from pre-retrofit conditions. Although owners of two of the seven homes discussed in this report did not return a completed survey, anecdotal evidence indicates that overall satisfaction is high for both. The owner of the Quincy Bungalow expressed enthusiasm for his low-energy home, even though this factor had not been a part of his original home renovation plans (Bartlett 2012). The owner of the HfHGL retrofit, the Bedford Farmhouse, also expressed deep satisfaction with her home to BSC consultants visiting the job site for final testing.

\subsection{Recommendations for Future Work}

One issue highlighted by this analysis is the importance of good data collection. The more information that is available for each project in a program such as National Grid, the easier it is 
to compare the overall performance of various projects in order to better show the benefits of these retrofit techniques to future participants. To present the information in this report, it was necessary to collect data from 5-10 sources for each home. These included homeowners, utility bills, National Grid utility tracking spreadsheets, National Grid DER Application spreadsheets, project plans, blower door testing reports, energy audit data, and energy models. With this diversity of sources, possible errors can arise from factors such as outdated file versions. However, all of the data can be considered essential for the understanding of project techniques, improvements achieved through the retrofits, costs, energy performance, and homeowner satisfaction.

The data collection challenge could be mitigated through the use of a user-friendly Internet database. The most updated project details could be kept in this database at all times.

Homeowners or their consultants participating in a monitoring program such as that of National Grid would be able to easily access the database and enter cost data, monthly energy use, and any relevant comments or observations about home performance. At the same time, it would be easy to compile and graph variables such as source energy over a year for all projects in the database. The ideal situation would be a database shared by all U.S. retrofit programs, allowing the comparison of large numbers of homes by different criteria. However, besides agreement on a suitable database format for such an endeavor, an enormous quantity of existing data would have to be painstakingly transferred. The BA House Performance Database, meant to store data for BA projects, is a step in the right direction. Suggested improvements to this database include entry fields for monthly utility data as available and the ability to generate reports or graphs of different attributes for a number of homes.

In addition to the challenges of data collection, there are a number of challenges in the comparison of results that are, to some extent, unique to DER projects. These include lack of pre-retrofit energy use, significant change in building use and size, changes in end-use energy, and increased use of renewables. As explored in Section 3.4, most projects lack sufficiently detailed data to normalize pre- and post-retrofit conditions to factors such as weather according to established methodologies. Less precise methodologies designed to accept typically available data would be a useful addition to the field.

BSC continues to be directly involved in 38 home retrofit projects that are part of the National Grid DER program. The homes discussed in this report are the only ones considered to have sufficient post-retrofit data for comparison at the time of this writing, but many more homes will generate similar data over the next year and beyond. It is very important that we continue to collect data from and monitor energy use of all of the homes that participated in the DER program so that quantitative and statistically significant conclusions about the expected benefit of strategies advocated by BSC can be made. The fact that the homes are all located in Massachusetts and use similar retrofit guidelines removes several sources of discrepancy, including typical existing building attributes, utility costs, and weather conditions.

In addition to energy use, longer term monitoring of these homes is likely to show the benefits of BSC strategies for durability and water management. Although "conventionally" designed building enclosures often lack best-practice water management strategies, problems generally do not appear immediately. It is hoped that durability benefits such as the prevention of ice dams 
(Figure 43) will become increasingly visible in the market, leading to more widespread adoption of these techniques.

Occupant comfort and satisfaction with the retrofit investment are also important market drivers. Owners of all seven of the homes discussed in this report expressed satisfaction with the decision to do the retrofits, but it would be interesting to note their feelings about the long term investment in 5 or 10 years. Changing utility costs over that time could strongly affect these attitudes. 


\section{Conclusions}

The seven projects discussed in this report can serve as examples of successful retrofits to typical New England style homes. Even with the incomplete pre- and post-retrofit utility data available, clear improvements in energy use and occupant comfort are observed from the strategies advocated by BSC and the National Grid DER program. Available data were used to calculate approximately $23 \%-74 \%$ energy savings with the addition of $11 \%-18 \%$ when the energy benefits of PV systems installed on three of the seven homes were included. The continued monitoring of these homes is important to the understanding of long-term energy performance.

Airtightness testing showed exceptional improvements from the pre-retrofit state for all of the homes. Two of the homes achieved the stringent National Grid DER goal of testing below 0.1 CFM $50 / \mathrm{ft}^{2}$ of building enclosure; two other homes came extremely close to this target.

Occupant survey results also indicate a very high level of satisfaction with the retrofit measures. Occupant feedback is extremely important, as it is impossible to collect these data simply by looking at utility bills, energy models, and blower door testing results. Homeowner satisfaction with these retrofits is essential considering the substantial investments that the homeowners have made in these projects. It is hoped that additional feedback about long-term energy performance, comfort, and durability will encourage others considering a comprehensive retrofit similar to those described. Most of the homes were able to remain occupied during the retrofits, which is more convenient and cost effective for families.

Data collection from these projects is critical to achieving widespread adoption in the United States, as this information can then be used to show performance trends for large numbers of homes. However, this is difficult to achieve because of the variety of data sources for each project. A more widely adopted, comprehensive, and easy-to-use database is needed to effectively collect information and allow easy comparison of key factors and performance among projects. 


\section{References}

ACI (2010). "1000 Home Challenge." An initiative of ACI (Affordable Comfort, Inc.). http://thousandhomechallenge.com/. Accessed September 2011.

ASHRAE (2002). "ASHRAE Guideline 14-2002 for Measurement of Energy and Demand Savings." Atlanta, GA: American Society of Heating, Refrigeration and Air Conditioning Engineers, Inc.

Bartlett, J. "National Grid's Deep Energy Retrofit Program gets local attention.” Boston.com, http://www.boston.com/yourtown/news/quincy/2011/09/national_grids_deep_energy_ret.html. Accessed January 2012.

BizEE. "Degree Days - Handle with Care!" BizEE Energy Lens: Energy Management Made Easy. http://www.energylens.com/articles/degree-days. Accessed January 3, 2012.

BSC (2007). "Guide to Insulating Sheathing". Building Science Corporation, http://www.buildingscience.com/documents/guides-and-manuals/gm-guide-insulatingsheathing/view?topic = doctypes/guides-and-manuals. Accessed January 7, 2011.

BSC (2008) Building America Deliverable 15.D.2, "Initial Occupied Home Evaluation Results." Building Science Corporation, Task Order No. KAAX-3-32443-15.

BSC (2009b). "Info-302: Pan Flashing for Exterior Wall Openings.” Building Science Corporation, www.buildingscience.com/documents/information-sheets/3-water-managementand-vapor-control/pan-flashing-for-exterior-wall-openings/view. Accessed January 7, 2011.

BSC (2009c). "Info-303: Common Flashing Details.” Building Science Corporation, www.buildingscience.com/documents/information-sheets/3-water-management-and-vaporcontrol/common-flashing-details/view. Accessed January 7, 2011.

BSC (May 2009d). "Info-406: Air Sealing Windows". Building Science Corporation, http://www.buildingscience.com/documents/information-sheets/4-air-barriers/air-sealingwindows?topic $=$ doctypes/information-sheets/4-air-barriers. Accessed January 7, 2011.

BSC (2009f). "Info-511: Basement Insulation". Building Science Corporation, http://www.buildingscience.com/documents/information-sheets/5-thermal-control/basementinsulation/. Accessed January 7, 2011.

BSC (2010). "Cold Climate: Bedford Farmhouse High Performance Retrofit Prototype". Building Science Corporation, www.buildingscience.com/documents/case-studies/cold-climatebedford-farmhouse-retrofit-case-study/view. Accessed January 7, 2011.

Energy Information Administration [EIA]. Annual Energy Review 2009. DOE/EIA-0384 Washington, DC, 2009. 
ENERGY STAR. "ENERGY STAR Performance Ratings Methodology for Incorporating Source Energy Use, www.energystar.gov/ia/business/evaluate_performance/ site_source.pdf. Accessed May 16, 2011.

Green Power Partnership. “Green Power Equivalency Calculator Methodologies.” U.S. Environmental Protection Agency, www.epa.gov/greenpower/pubs/calcmeth.htm \#coalplant. Accessed September 9, 2011.

Irving, B. "Tale of Three Decks: The Jamaica Plain House.” This Old House, www.thisoldhouse.com/toh/tv/house-project/overview/0,,197962,00.html. Accessed May 4, 2011.

Kissock, J.; Haberl, J.; Claridge, D. (2002). "Development of a Toolkit for Calculating Linear, Change-point Linear and Multiple-Linear Inverse Building Energy Analysis Models.” ASHRAE Research Project 1050-RP. Atlanta, GA: American Society of Heating, Refrigeration and Air Conditioning Engineers, Inc.

Lstiburek, J.W. (2006). "Understanding Basements.” ASHRAE Journal (vol. 48); pp. 24-29. Atlanta, GA: American Society of Heating, Refrigeration, and Air-Conditioning Engineers, Inc.

Lstiburek, J.W. (2010). "Building Sciences: Rubble Foundations." ASHRAE Journal (vol. 52); pp. 72-78. Atlanta, GA: American Society of Heating, Refrigeration, and Air-Conditioning Engineers, Inc.

National Grid. (2011). "Deep Energy Retrofit Multifamily and Single-family Pilot Guidelines" Norton, P.; Burch, J.; Hendron, B. (2008). "Project Closeout: Guidance for Final Evaluation of Building America Communities.” NREL/TP-550-42448. Golden, CO: National Renewable Energy Laboratory.

Orr, H.W.; Dumont, R.S. (May 1987). “A Major Energy Conservation Retrofit of a Bungalow." Internal Report No. 540: National Research Council Canada.

Pettit, B. (2009). "Cold Climate: Concord Four Square Retrofit." Building Science Corporation, www.buildingscience.com/documents/case-studies/cs-climate-concord-four-square-retrofit/view.

SEE Action. (2011). "Roadmap for the Home Energy Upgrade Market." Residential Building Retrofits Working Group, June 2011.

Ueno, K. (2010). "Residential Exterior Wall Superinsulation Retrofit Details and Analysis." Performance of the Exterior Envelopes of Whole Buildings XI. Atlanta, GA: American Society of Heating, Refrigeration, and Air-Conditioning Engineers, Inc. 


\section{Appendix A}

Questionnaire on the Energy Use and Comfort of Your Home

\section{PLEASE COMPLETE AND RETURN THIS QUESTIONNAIRE WITHIN 6 DAYS}

This short questionnaire is designed to help us understand the energy use within your home as part of a home energy study sponsored by the U.S. Department of Energy. It will be used in conjunction with an analysis of your utility bills. Your name will be kept confidential and will not appear in publications of the results of this study.

How many people are currently living in your home? [Please type an " $\mathrm{x}$ " for one response.]

\section{1 \\ 2 \\ 3 \\ 4 \\ 5 \\ 6}

More than 6 - Please enter the number of people living in your home:

How many television sets do you have? [Please type an "x" for one response.]
1
2
3
4
5
6

More than 6 - Please enter the number of television sets:

How many desktop computers do you have? [Please type an " $\mathrm{x}$ " for one response.] 
More than 6 - Please enter the number of desktop computers in your home:

Is there generally someone at home all day on the weekdays? [Please type an " $x$ " for one response.]

$\square$ Yes

\section{$\square$ No}

At what temperature do you set your thermostat during the day in the winter?

[Please type an " $\mathrm{x}$ " for one response.]

$\square 68^{\circ} \mathrm{F}$

$69^{\circ} \mathrm{F}$

$70^{\circ} \mathrm{F}$

$\square 71^{\circ} \mathrm{F}$

$\square 72^{\circ} \mathrm{F}$

$\square 73^{\circ} \mathrm{F}$

$\square 74^{\circ} \mathrm{F}$

Other - Please enter your thermostat setting: ${ }^{\circ} \mathrm{F}$

At what temperature do you set your thermostat during the day in the summer?

[Please type an " $\mathrm{x}$ " for one response.]

$\square 73^{\circ} \mathrm{F}$

$\square 74^{\circ} \mathrm{F}$

$\square 75^{\circ} \mathrm{F}$

$\square 76^{\circ} \mathrm{F}$ 
$77^{\circ} \mathrm{F}$

$\square 78^{\circ} \mathrm{F}$

$\square 79^{\circ} \mathrm{F}$

Other - Please enter your thermostat setting: ${ }^{\circ} \mathrm{F}$

Do you change your thermostat settings at night?

Yes

No

Do you use natural ventilation (opening windows at night) to avoid air conditioner and ventilation system use?

Yes

$\square$ No

Please indicate if you have any of the following items in your home:

Second refrigerator

If you know the approximate model year, please enter it here

Independent freezer (not part of a refrigerator)

Plasma TV

Microwave oven

$\square$ Cable or satellite TV control box

Dehumidifier

Whole house fan (attic fan)

Window air conditioner

If checked, please indicate how many window air conditioners there are in your home:

Portable electric heaters

If checked, please indicate how many portable electric heaters you use in your home: 
Aquarium

If you know the number of gallons, please enter it here:

Ceiling fans

If checked, please indicate how many ceiling fans are in your home:

Hot water circulation pump

\section{PLEASE USE THE SPACE BELOW TO TELL US OF ANY POTENTIALLY HIGH ENERGY}

USES IN YOUR HOME. Examples include a welding or woodworking shop, a large number of grow lights for houseplants, an electric car, and a hobby that requires electricity or natural gas.

Please indicate the extent to which you agree or disagree with the following statements.

[For each statement, please put parenthesis ( ) around one response.]

Strongly Disagree Neutral/ Agree Strongly

Disagree Unsure Agree

1. My home was comfortable in winter

before the retrofit.

$\begin{array}{lllll}1 & 2 & 3 & 4 & 5\end{array}$

2. My home is comfortable in winter

(after the retrofit).

$\begin{array}{lllll}1 & 2 & 3 & 4 & 5\end{array}$

3. My home was comfortable on warm/hot days

before the retrofit

$\begin{array}{lllll}1 & 2 & 3 & 4 & 5\end{array}$

4. My home is comfortable on warm/hot days

(after the retrofit).

$\begin{array}{lllll}1 & 2 & 3 & 4 & 5\end{array}$


5. My home sometimes feels "stuffy."

$\begin{array}{lllll}1 & 2 & 3 & 4 & 5\end{array}$

If you answered "strongly agree" or "agree," during what season does this occur?

6. All rooms in my home are equally comfortable.

$\begin{array}{lllll}1 & 2 & 3 & 4 & 5\end{array}$

7. I am satisfied with the overall comfort of my home.

$\begin{array}{lllll}1 & 2 & 3 & 4 & 5\end{array}$

8. My home has low utility bills for its size.

$\begin{array}{lllll}1 & 2 & 3 & 4 & 5\end{array}$

9. The HVAC control systems in my home are easy to operate.

$\begin{array}{lllll}1 & 2 & 3 & 4 & 5\end{array}$

10. I am satisfied with my home overall.

$\begin{array}{lllll}1 & 2 & 3 & 4 & 5\end{array}$

11. The low energy features of my home are important to me.

$\begin{array}{lllll}1 & 2 & 3 & 4 & 5\end{array}$

PLEASE USE THE SPACE BELOW FOR ANY FURTHER COMMENTS YOU HAVE ABOUT YOUR HOME. THANK YOU FOR PARTICIPATING IN THIS STUDY! 
buildingamerica.gov

\section{U.S. DEPARTMENT OF Energy Efficiency \& ENERC Renewable Energy}

DOE/GO-102012-3529 - June 2012 